\title{
Prevention of Post-Operative Adhesions: A Comprehensive Review of Present and Emerging Strategies
}

\author{
Ali Fatehi Hassanabad ${ }^{1}$, Anna N. Zarzycki ${ }^{1}$ (D, Kristina Jeon ${ }^{2}$, Jameson A. Dundas ${ }^{1}$, Vishnu Vasanthan ${ }^{1}$, \\ Justin F. Deniset ${ }^{1,3}$ and Paul W. M. Fedak $1, * \mathbb{D}$ \\ 1 Section of Cardiac Surgery, Department of Cardiac Sciences, Libin Cardiovascular Institute, Cumming School \\ of Medicine, University of Calgary, Calgary, AB T2N 2N9, Canada; ali.fatehihassanabad@ahs.ca (A.F.H.); \\ annazarzycki00@gmail.com (A.N.Z.); jameson.dundas@ucalgary.ca (J.A.D.); \\ vishnu.vasanthan@ucalgary.ca (V.V.); jdeniset@ucalgary.ca (J.F.D.) \\ 2 Department of Anesthesiology and Pain Medicine, Faculty of Medicine and Dentistry, University of Alberta, \\ Edmonton, AB T6G 2R7, Canada; kjeon@ualberta.ca \\ 3 Department of Physiology and Pharmacology, University of Calgary, Calgary, AB T2N 1N4, Canada \\ * Correspondence: paul.fedak@gmail.com
}

check for

updates

Citation: Fatehi Hassanabad, A.; Zarzycki, A.N.; Jeon, K.; Dundas, J.A.; Vasanthan, V.; Deniset, J.F.; Fedak, P.W.M. Prevention of Post-Operative Adhesions: A Comprehensive Review of Present and Emerging Strategies. Biomolecules 2021, 11, 1027. https:// doi.org/10.3390/biom11071027

Academic Editors: Vladimir N Uversky and Ryan Moseley

Received: 6 June 2021

Accepted: 7 July 2021

Published: 14 July 2021

Publisher's Note: MDPI stays neutral with regard to jurisdictional claims in published maps and institutional affiliations.

Copyright: (C) 2021 by the authors Licensee MDPI, Basel, Switzerland. This article is an open access article distributed under the terms and conditions of the Creative Commons Attribution (CC BY) license (https:/ / creativecommons.org/licenses/by/ $4.0 /)$.

\begin{abstract}
Post-operative adhesions affect patients undergoing all types of surgeries. They are associated with serious complications, including higher risk of morbidity and mortality. Given increased hospitalization, longer operative times, and longer length of hospital stay, post-surgical adhesions also pose a great financial burden. Although our knowledge of some of the underlying mechanisms driving adhesion formation has significantly improved over the past two decades, literature has yet to fully explain the pathogenesis and etiology of post-surgical adhesions. As a result, finding an ideal preventative strategy and leveraging appropriate tissue engineering strategies has proven to be difficult. Different products have been developed and enjoyed various levels of success along the translational tissue engineering research spectrum, but their clinical translation has been limited. Herein, we comprehensively review the agents and products that have been developed to mitigate post-operative adhesion formation. We also assess emerging strategies that aid in facilitating precision and personalized medicine to improve outcomes for patients and our healthcare system.
\end{abstract}

Keywords: post-surgical adhesions; immune mediators; pharmaceuticals; barriers; biomaterials

\section{Introduction}

Surgical adhesions are pathological fibrotic connections that form between organ surfaces and the walls of surrounding body cavities following tissue trauma and ischemia. Post-surgical adhesions can range from thin films of connective tissue to thick fibrous bridges that are vascularized and innervated [1]. Despite improvements in surgical technique, adhesions are a common post-surgical complication, developing after 50-95\% of all operations regardless of procedure or anatomical location [2-4]. Adhesion formation following pelvic, peritoneal, and thoracic operations have been the focus of much of the current literature [5-11]. Adhesions represent a significant clinical problem that impacts millions of patients annually [12]. They cause complications such as severe chronic pain, organ dysfunction, and increase the risk of repeat surgeries, including surgeries to address the adhesions themselves. In the operating room, adhesions increase the risk profile at the time of repeat operation due to hemorrhage, perforation, reduced surgical exposure, and prolonged operative times [13-17], while also conferring major financial burden on the healthcare system [18-22].

Although the clinical impact of post-operative adhesions is appreciated, the pathophysiology of adhesions formation and mechanisms underlying their formation are not yet fully established. Studies have suggested that adhesion formation is a dynamic but 
dysregulated regenerating tissue repair process that can be characterized by distinct cellular and immune responses [23-25]. An important feature of tissue repair and potential pathologic adhesion formation is the local inflammatory response, tissue damage, and hypoxia induced by surgical trauma [26-28]. Post-surgical adhesion formation involves three core processes: (1) inhibition of the fibrinolytic and extracellular matrix degradation systems, (2) the induction of an inflammatory response involving the production of cytokines and transforming growth factor- $\beta$ (TGF- $\beta$ ), and (3) induction of tissue hypoxia, leading to increased expression of vascular endothelial growth factor (VEGF) [29]. Factors that have been implicated in post-operative adhesion formation are summarized in Table 1.

Given our poor understanding of the pathophysiology of post-surgical adhesion formation, there is an unmet clinical need for the development of safe and effective therapeutic options that can be used to mitigate them. Different pharmacological strategies have been employed to reduce adhesion formation, severity, and chronicity. Biomaterials have also been designed to act as tissue barriers that can physically isolate wounds and have been shown to prevent the formation of adhesions to varying degrees of success. In an effort to facilitate precision medicine, groups have recently assessed the potential of nanoparticles and gene therapy in preventing post-surgical adhesion formation, although their clinical translation has been limited. Herein, we comprehensively review the major types of established and emerging strategies that have been used to prevent or lessen post-operative adhesion formation in various types of surgeries. We also offer our perspective on how emerging methods can be effectively translated clinically.

Table 1. Cellular and signalling pathways involved in adhesion formation.

\begin{tabular}{|c|c|c|c|}
\hline Factor & Component & Role in Adhesion Formation & Reference \\
\hline Surgical Trauma & & $\begin{array}{c}\text { Increase of fibrin } \\
\text { Increase levels of plasminogen activator inhibitor } \\
\text { Induction of local inflammatory response } \\
\text { Hypoxia and reactive oxygen species (ROS) release } \\
\text { leading to inflammation and activation of } \\
\text { coagulation cascade } \\
\text { Surgical hypoxia may decrease fibrinolysis }\end{array}$ & {$[16,23,26-28,30-34]$} \\
\hline $\begin{array}{l}\text { Extracellular Matrix } \\
\text { Components }\end{array}$ & $\begin{array}{l}\text { Fibronectin, hyaluronic } \\
\text { acid, glycosaminoglycans, } \\
\text { proteoglycans }\end{array}$ & $\begin{array}{l}\text { Matrix for proliferation of cellular components } \\
\text { Secreted by fibroblasts }\end{array}$ & {$[35,36]$} \\
\hline \multirow[t]{4}{*}{ Cellular Mediators } & & & {$[37,38]$} \\
\hline & $\begin{array}{l}\text { Fibroblasts and } \\
\text { Myofibroblasts }\end{array}$ & $\begin{array}{c}\text { Subperitoneal fibroblast deposition required for } \\
\text { adhesion development } \\
\text { Transition to myofibroblast phenotype associated } \\
\text { with long-lasting adhesions } \\
\text { Maturation of adhesions through collagen and } \\
\text { extracellular matrix (ECM) production }\end{array}$ & [39-48] \\
\hline & Mesothelial Cells & $\begin{array}{c}\text { Potential protective role } \\
\text { Insult induces pro-fibrotic phenotype and secretion } \\
\text { of inflammatory mediators, cells, and ECM } \\
\text { components that contribute to immune cell } \\
\text { recruitment and coagulation } \\
\text { Mesothelial to mesenchymal transition (MMT) } \\
\text { drives adhesion formation }\end{array}$ & [49-53] \\
\hline & Macrophages & $\begin{array}{l}\text { Identified in long-lasting adhesions } \\
\text { Fundamental in adhesion formation } \\
\text { Secrete fibrinolytic mediators and interleukins } \\
\text { Recruit and influence mesothelial cells }\end{array}$ & [54-59] \\
\hline
\end{tabular}


Table 1. Cont.

\begin{tabular}{|c|c|c|c|}
\hline Factor & Component & Role in Adhesion Formation & Reference \\
\hline & Neutrophils & $\begin{array}{c}\text { Recruited by activated mesothelial cells } \\
\text { Release ROS, inhibiting fibrinolysis and exerting a } \\
\text { direct cytotoxic effect on mesothelial cells } \\
\text { Debated in the literature to have both a pro- and } \\
\text { anti-adhesive effect }\end{array}$ & {$[50,60-64]$} \\
\hline & T Lymphocytes & $\begin{array}{c}\text { Persist in quality and quantity in long-lasting } \\
\text { adhesions } \\
\text { Th1, Th2, and Treg CD4+ phenotypes implicated in } \\
\text { adhesion formation } \\
\text { Produce pro-inflammatory cytokines }\end{array}$ & {$[54,65-67]$} \\
\hline
\end{tabular}

High concentrations in post-surgical adhesions

Release histamines, serotonin, cytokines, serine

Mast Cells proteases, vascular endothelial growth factor

(VEGF), and chymase
Deficiencies in mast cells reduce adhesion formation

[68-70]

\begin{tabular}{|c|c|c|c|}
\hline \multicolumn{4}{|l|}{ Signalling Factors } \\
\hline & Coagulation Cascade & Production of thrombin, key activator of fibrin & [23] \\
\hline & Fibrin-Fibrinolysis Balance & $\begin{array}{l}\text { Disruption of balance between fibrin production and } \\
\text { fibrinolysis leads to adhesion formation } \\
\text { Dysregulation between plasminogen-plasmin, and } \\
\text { plasminogen activator inhibitors (PAIs) } \\
\text { Fibrin matrix allows fibroblast adhesion and ECM } \\
\text { maturation }\end{array}$ & {$[71,72]$} \\
\hline & Matrix Metalloproteinases & $\begin{array}{c}\text { Post-surgical shifts in ratios of matrix } \\
\text { metalloproteineases (MMPs) to tissue inhibitors of } \\
\text { MMPs (TIMPs) } \\
\text { MMP-2/9 proposed as markers for adhesion } \\
\text { formation } \\
\text { Chronic suppression of MMP/TIMP ratios lead to } \\
\text { adhesions }\end{array}$ & [73-77] \\
\hline & Interleukins & $\begin{array}{c}\text { High concentrations in adhesion sites and some } \\
\text { direct correlations to extend of adhesion formation } \\
\text { Pro-inflammatory effects } \\
\text { Increased recruitment of immune cells }\end{array}$ & {$[38,78-86]$} \\
\hline & TNF- $\alpha$ & $\begin{array}{l}\text { Abundant in peritoneal fluid post-surgery } \\
\text { Increases interleukin production }\end{array}$ & {$[87,88]$} \\
\hline & TGF- $\beta$ & $\begin{array}{c}\text { Key fibrotic mediator } \\
\text { Elevated in adhesions } \\
\text { Stimulates myofibroblast migration and activation } \\
\text { Chemotactic for neutrophils, T-cells, monocytes, and } \\
\text { fibroblasts } \\
\text { Induces ECM production } \\
\text { Inhibits matrix degradation by altering ratio of } \\
\text { protease to protease inhibitors }\end{array}$ & {$[82,89-94]$} \\
\hline & VEGF & $\begin{array}{l}\text { Promotes angiogenesis, involved in coagulation and } \\
\text { fibrinolysis } \\
\text { Increases vascular permeability and promotes fibrin } \\
\text { matrix deposition }\end{array}$ & [95-97] \\
\hline
\end{tabular}

\section{Surgical Approaches and Adhesions}

Some groups have hypothesized that minimally invasive surgical approaches may reduce the risk of post-operative adhesion formation. This has been based on the theory that minimally invasive approaches lead to less trauma, which should result in less post-injury 
repair processes being activated [98-100]. However, literature has yet to conclusively prove that this is indeed the case in clinical practice. A systematic review and meta-analysis of different surgical techniques, including laparotomy and laparoscopy, found that various approaches did not reduce post-operative peritoneal adhesions, small bowel obstruction, or infertility rates [101]. In contrast, some preclinical and clinical studies have shown that laparoscopic approaches reduce the rate of post-operative adhesions, especially in the context of adhesiolysis [102-104]. It is also important to note that some of the benefits of minimally invasive surgery with respect to post-operative adhesion formation may be limited given the use of pneumoperitoneum with the use of $\mathrm{CO}_{2}$. Pneumoperitoneum is associated with increased intra-abdominal pressure, which may compromise normal blood flow and result in ischemic injury, including acidosis and production of reactive oxygen species (ROS) [30,105-109]. The potential role of temperature and humified gas in postsurgical adhesion formation has also been assessed in pre-clinical studies. Hypothermia with a humidified gas mixture of $\mathrm{CO}_{2}, \mathrm{~N}_{2} \mathrm{O}$, and $\mathrm{O}_{2}$ seems to provide the biggest impact in preventing post-operative intra-abdominal adhesion formation in rodents [110,111]. Ultimately, meticulous and minimal tissue handling, preventing thermal injury, optimal hemostasis, maintaining a moist operative field, reducing the risk of infection, and avoiding the use of foreign body material may be the most important factors in reducing the formation of post-operative adhesions [112].

\section{Pharmaceutical Strategies for Adhesion Prevention}

Different classes of medications and pharmaceuticals have been assessed for their anti-adhesive properties. Groups have investigated these agents based on their effects on various mechanisms that have been implicated in adhesion formation, including the coagulation cascade and different components of inflammatory pathways.

\subsection{Agents Targeting Angiotensin}

The renin-angiotensin-aldosterone system (RAAS) is the principal regulator of blood pressure; recent studies also indicate the vital role of RAAS in inflammation, proliferation, and fibrosis pathways, and particularly in post-surgical adhesions [113-119]. Renin cleaves angiotensinogen to produce the inactive peptide angiotensin I, which is further cleaved by the angiotensin-converting enzyme (ACE) to produce the active peptide angiotensin II (although there are alternative routes). Most of the known functions of the RAAS are mediated through the activation of the angiotensin II type 1 receptor $\left(\mathrm{AT}_{1}\right.$ receptor) by angiotensin II [120]. Angiotensin, the main peptide of the RAAS, has proinflammatory and pro-fibrotic activity, inducing cell hypertrophy, the expression of extracellular matrix proteins, and promoting TGF- $\beta$ and other profibrotic molecule signalling [121,122].

Angiotensin type $1\left(\mathrm{AT}_{1}\right)$ receptor antagonists are known to reduce plasminogen activator inhibitor-1 (PAI-1) expression, which is a key component of the fibrin productionfibrinolytic balance [123-125]. In a rat model of intra-peritoneal adhesions, the administration of candesartan, the $\mathrm{AT}_{1}$ receptor agonist, resulted in a marked decrease in the severity of intra-peritoneal adhesions and PAI-1 mRNA expression [126]. No human studies have thus far focused on the use of $\mathrm{AT}_{1}$ receptor antagonists for preventing adhesion formation. Compound $21(\mathrm{C} 21)$ is a small molecule angiotensin type $2\left(\mathrm{AT}_{2}\right)$ receptor agonist. Contrary to $\mathrm{AT}_{1}$ receptor agonists, engagement of $\mathrm{AT}_{2}$ receptors by angiotensin II leads to anti-fibrotic effects, particularly the down-regulation of TGF- $\beta$ [127]. C21 has been shown to reduce fibrosis associated with myocardial infarction, stroke, renal disease, and idiopathic pulmonary fibrosis [128-131]. C21 is also reported to reduce intra-peritoneal adhesion formation in mice, and has inhibitory effects on mesothelial cell and peritoneal fibroblast migration, TGF- $\beta$ levels, and pSMAD2/3 expression, all of which have been shown to contribute to adhesion formation [132].

Angiotensin converting inhibitors (ACE-I) have been used to suppress growth factor signalling and attenuate the formation of fibrosis and post-operative adhesions [133]. ACE-I has been suggested to target the epidermal growth factor (EGF) and/or the TGF- $\beta$ 
signalling cascades [133]. Administration of high-doses of ACE-I impair post-operative wound and bowel anastomotic healing, while low doses do not [134]. Studies have also demonstrated a decrease in TGF- $\beta$-mediated mesothelial fibrosis with ACE-I and angiotensin receptor blockers in vitro [135]. Taken together, these studies indicate that there is a potential benefit in targeting angiotensin receptors and related enzymes for reducing adhesion formation. However, more clinical studies are required to better assess the role these agents can have in the clinical setting.

\subsection{Hypoxia-Inducible Factors (HIF) Inhibitor and N-Acetyl-Cysteine}

Hypoxia has been shown to play a key role in adhesion formation, so studies have investigated whether inhibiting hypoxia-driven pathways is beneficial in mitigating postsurgical adhesion formation $[83,136]$. Administration of HIF-inhibitor in mice before and after induction of peritoneal adhesions has been associated with a recent study, which showed that disruption of the HIF1-alpha pathway using small molecule inhibitor, YC1 (3-[5'-Hydroxymethyl-2'-furyl]-1-benzyl-indazole), was sufficient to curtail adhesion formation in a mouse model of peritoneal adhesions [137]. Administration of this HIF-alpha inhibitor was associated with compromised pro-inflammatory activation of macrophages, reduced activation of peritoneal fibroblasts, and enhanced fibrinolysis [137]. With the growth of specific and targeted monoclonal antibodies [138], leveraging the HIF1-alpha pathway for preventing adhesion development has great clinical promise as it will facilitate precise and personalized medicine.

$\mathrm{N}$-acetyl-cysteine (NAC) is a precursor of glutathione and an antioxidant bearing sulfhydryl groups with excellent free radical scavenging. The generation of harmful ROS plays a key role during postoperative adhesion formation following hypoxic conditions. $\mathrm{N}$-acetyl-cysteine has been found to be effective in preventing post-operative pericardial adhesions in a rabbit model when applied with a sponge, which was then removed from the surgical site [139]. The authors postulate that this effect may be largely attributed to the anti-fibrotic capacity of NAC as well as its ability to serve as a physical barrier between serosal surfaces, which is not well explained. Other studies have reported that NAC decreases abdominal adhesion formation in rats via the upregulation of peritoneal fibrinolytic activity [140]. For there to be a meaningful clinical translation and application more in vitro and in vivo studies are warranted.

\subsection{3-Hydroxy-3-Methylglutaryl Coenzyme A (HMG-CoA) Reductase Inhibitors}

Statins are a class of lipid-lowering medications that inhibit HMG-CoA reductase (HMGCR), the rate-limiting enzyme of the mevalonate pathway. Statins have also been demonstrated to have anti-inflammatory and pro-fibrinolytic capabilities [141], and have anti-adhesive properties within their therapeutic dose range [142]. In a rat model, oral fluvastatin administered after peritoneal surgery significantly reduced adhesions, which was attributed to an upregulation of matrix metalloproteinase (MMP)-9 expression, an important regulator of extracellular matrix production [143]. Additionally, fluvastatin down-regulated the levels of IL-1b, a pro-inflammatory cytokine, and inhibited the invasion of inflammatory cells, resulting in a reduction in fibrous adhesion formation and an increase in the activity of tPA [143]. Similar results have been obtained using lovastatin and atorvastatin, which have been mechanistically identified to increase tPA mRNA levels in peritoneal tissue and tPA activity, leading to the upregulation of local fibrinolysis [144]. More studies are needed to further assess the role this class of medications can have in preventing post-surgical adhesion formation.

\subsection{Neurokinin-1 Receptor (NK-1R) Antagonist}

One of the main ligands of Neurokinin-1 Receptor (NK-1R) is the pro-inflammatory peptide substance $\mathrm{P}$, which is involved in inflammation and wound healing, and may be an important signalling molecule in peritoneal adhesion formation [145]. The application of NK-1R agonists in animal models of post-operative adhesions leads to significant reduction 
in adhesions, as well as increased activity of MMPs, fibrinolysis, and lower levels of oxidative stress [145-149]. A substance P receptor antagonist (SPRA) that reduced intraabdominal adhesion formation in rats also decreased peritoneal MMP activity [150]. These preclinical studies have provided some insight into the potential impact NK-1R mediators can have in mitigating post-surgical adhesion formation, but more robust data is needed to further advance them into the clinical setting.

\subsection{Lubricin}

Lubricin is a mucin-like proteoglycan that has been found in various tissue compartments, including synovial fluid [151] and the eyes [152]. Many in vitro and in vivo studies have found lubricin to have anti-adhesive and anti-inflammatory properties [153]. A recent study by our group showed for the first time that lubricin exists in human pericardial fluid [43]. We found that lubricin localizes to the pericardial mesothelial layer and prevents myofibroblast attachment and activity. Using a porcine model, our group also showed that the removal of pericardial fluid is associated with severe pericardial adhesions, while adding lubricin to the pericardial space resulted in fewer and less severe adhesions in the early post-operative stages [43]. Further study and validation are required to delineate the mechanism of action of lubricin in preventing adhesion formation and its translation into clinical practice.

\subsection{Chymase Inhibitor and Sodium Cromoglycate}

Chymase is an inflammatory mediator released from mast cells and is involved in tissue fibrosis $[154,155]$. The administration of various chymase inhibitors has resulted in lower adhesion formation and decreased TGF- $\beta$ levels in multiple preclinical animal models of peritoneal and pericardial adhesions [156-162]. However, in a hamster model of peritoneal adhesions, moderate to severe adhesions persisted in $18 \%$ of hamsters regardless of chymase inhibitor use, suggesting that the dosing and administration of the inhibitor requires further optimization [156]. On the other hand, sodium cromoglycate stabilizes mast cell membranes and prevents the release of histamine and other biochemical mediators. Intra-peritoneal instillation of sodium cromoglycate in a rabbit model of pelvic adhesions demonstrated efficacy in reducing the incidence of adhesion formation, both individually and when combined with saline, dexamethasone, and aprotinin [163]. As is the case with many pharmaceutical agents discussed here, more robust preclinical and clinical studies are needed to better understand the potential impact these agents can have in preventing or minimizing post-operative adhesion formation.

\subsection{NSAIDs and Anti-Inflammatory Drugs}

Administration of non-steroidal anti-inflammatory drugs (NSAIDs) has been shown to decrease peritoneal, pelvic, and tendon adhesions in rabbit, hamster, guinea pig, and porcine models [164-176]. Although the exact mechanism by which they exert this effect is unclear, it is likely secondary to their inhibition of cyclooxygenase 2 (COX-2), which leads to decreased production of prostaglandins in the inflammatory cascade [177]. In murine models of peritoneal adhesions administration of COX-2 inhibitors, such as celecoxib, tenoxicam, and pentoxifylline, reduced post-operative adhesions through their antiangiogenic, anti-inflammatory, and antioxidant effects [178-183]. Furthermore, NSAIDs block the production of thromboxanes, which are reportedly involved in biochemical pathways leading to adhesion formation [184]. Selective inhibition of thromboxane production via NSAID administration can be a potential strategy for reducing adhesion formation and severity [169]. Nevertheless, given their systemic side effects such as peptic ulcer disease, acute renal failure, electrolyte and fluid abnormalities, increase risk of adverse cardiovascular events, hepatotoxicity, bronchospasm, cognitive dysfunction, and various skin reactions [185-191], a scenario where NSAIDs can be delivered locally and show the same anti-adhesive efficacy would be optimal. Indeed, early studies of locally injected NSAIDs and anti-thromboxane agents in a rabbit uterine horn model were efficacious in 
reducing the severity of adhesion [184]. However, no in-human trials have been performed to examine the efficacy of NSAIDs in the reduction of post-surgical adhesions. Now, more contemporary studies have moved away from local or systemic NSAID administration and instead imbued NSAIDs into inert physical barriers. This approach for adhesion prevention will be discussed below.

\subsection{Alcohol}

Ethanol has been assessed in a porcine pericardial adhesion model [192,193]. One study supplemented the diets of the subjects with alcohol and compared the effects with a sucrose-supplemented diet group. There was evidence of fewer adhesions, thinner pericardial thickness, and decreased intra-myocardial fibrosis in the alcohol group [192]. Groups have yet to explain the rationale behind these observations, and there are currently no studies that have considered the anti-adhesive properties of alcohol in a clinical setting.

\subsection{Small Molecule Inhibitors}

Small molecule inhibitors are gaining more attention in various clinical settings. Pirfenidone, a novel small molecule inhibitor, acts by reducing inflammatory cytokines such as TNF- $\alpha$, monocyte chemotactic factor-1, IL-1 $\beta$ and IL-6; down-regulating profibrotic growth factors, including TGF- $\beta$; and reducing lipid peroxidation and oxidative stress [194]. In a postoperative peritoneal adhesion rat model, pirfenidone has demonstrated efficacy in preventing adhesion formation [195]. In a murine model, actin modulators, including CK-666, Rhosin, and Golgicide A, and a calcium channel antagonist, Bepridil, have been found to robustly inhibit adhesion formation following daily peritoneal injections for five days [196]. Moreover, a single early localized administration of the above compounds in a $2 \%$ cellulose compound was also successful in preventing adhesion formation [196]. As a proof of concept, this study suggests that calcium signalling can potentially be targeted in a precise manner in order to prevent adhesion formation.

Trametinib is a small molecule kinase inhibitor of mitogen-activated extracellular signal regulated kinase (MEK) 1 and 2. In a mouse model of abdominal adhesions, trametinib effectively blocked macrophage to myofibroblast transition in vitro and markedly diminished adhesion formation in vivo, likely by inhibiting the activation of Erk1/2 [197]. This data suggests that activation of Erk1/2 signalling pathways can be a common pathophysiological mechanism in adhesion formation and other fibrotic reactions. The activation of these signalling pathways induces the production of collagen-containing extracellular matrix (ECM) as well as a transition to a myofibroblast phenotype in resident cells [198]. The small molecular inhibitor QLT-0267 has been reported to attenuate fibrin-induced IL-1 $\beta$, IL-6, TNF $\alpha$, and VEGF-A expression in polymorphonuclear cells [199]. This study demonstrates that fibrin, the key component of the initial adhesion matrix, not only apposes two peritoneal surfaces but could also augment peritoneal inflammation and cause peritoneal adhesions. The study also indicates that fibrin-induced cytokine production can be involved in the mechanism of peritoneal adhesion formation.

Work has demonstrated the efficacy of T-5224, a selective small molecule activator protein (AP)-1 inhibitor used in a variety of fibrotic pathologies and shown to block early and late AP-1-induced cytokine responses [200]. The gene JUN has recently been identified as a transcriptional master regular of fibroblasts and has been shown to be expressed in human adhesion fibroblasts [40]. JUN expression is an early promoter of abdominal adhesions, upregulating fibrotic signalling pathways in both mouse and human adhesion formation models [40]. T-5224 has also been shown to suppress JUN signalling in mouse adhesion fibroblasts in vitro, and intra-abdominal application in vivo demonstrated a dramatic decrease in adhesion formation, with histological examination revealing thinner and less fibrotic adhesions. 


\subsection{Hormones and Other Pharmacological Agents}

Estrogen is a steroidal hormone mainly produced by ovaries, placenta, and to a lesser extent the adrenal cortex. Estradiol has been reported to have a significant effect on the formation of pelvic adhesions after myometrial operation in non-human primates [201]. Intraperitoneal administration of estrogen has been shown to reduce abdominal adhesion formation in a rat model [202]. A systemic review examining the efficacy of estrogen therapy in patients with intrauterine adhesions concluded that estrogen therapy is beneficial to patients with adhesions regardless of the severity [203].

Ghrelin is a gastric peptide hormone that has been identified to have anti-fibrotic and anti-inflammatory actions [204]. Intraperitoneal administration of exogenous acylated ghrelin has been found to reduce the formation of post-operative abdominal adhesions in a murine model [205]. This anti-adhesion effect has been confirmed and mechanistically identified to involve the down-regulation of the pro-inflammatory gene and protein expression, including TGF- $\beta 3$ and TGF $\beta-R 2$ [206]. Other methods, including anticoagulants, antioxidants, antihistamines, melatonin, or neutralizing of fibrinolytic inhibitors, and inflammatory cytokines have also been investigated [207-215]. Although some of these agents showed positive results in animal studies, no conclusive data supporting their efficacy have been reported from the aforementioned studies.

While the use of pharmaceutical agents alone has potential to prevent tissue adhesion formation, there are certain drawbacks related to off target and adverse effects. For example, fibrinolytic agents can lead to dysregulation of the coagulation system and uncontrolled bleeding [216], whereas NSAIDs contribute to immune-suppression and a delayed healing process as well as a host of potential adverse effects [217,218]. While agents targeting various mediators in the RAAS are typically well tolerated, RAAS activity is regulated systemically and locally in a manner in a variety of systems and tissues [219]. The potential for the development of adverse and unanticipated effects is high due to the intertwined nature. Regarding HIF inhibitors, the use of many is dampened by their off-target effects, affecting different pathways in DNA replication, cell division, or cell signaling [220]. HMG-CoA reductase inhibitors have been hypothesized to influence intracellular signaling pathways and immune processes [221,222]; their several pleiotropic off-target effects have been investigated in cancer therapy by delaying DNA repair and inducing senescence [223]. Chymase inhibitors have off-target effects linked to various biological pathways such as the complement system, intrinsic, and extrinsic pathways of coagulation cascade, and fibrinolytic system [224]. These exemplify significant issues that have contributed to the limited clinical translation of pharmaceutical agents that have been used for preventing or minimizing post-surgical adhesion formation.

\section{Inert Polymers in Adhesion Prevention Strategies}

Given the aforementioned challenges with potential anti-adhesive drugs, including lack of clinical efficacy, groups have assessed the safety, feasibility, and efficacy of physical barriers that can be used to prevent or lessen the severity of post-operative adhesions.

\subsection{Barriers}

Barriers are based on the hypothesis that preventing physical contact between two injured tissue or cell surfaces will prevent adhesion formation. These products can be generally classified into solid barriers, gels, and solutions. Bioactive functional barriers have been developed by embedding anti-adhesive drugs into barriers. Research has shown that key bioactive mediators driving post-surgical adhesions are present up to 7 days after an operation. An ideal barrier would be placed on the site of injury and be degraded safely after 7 days to prevent future complications. However, the introduction of barriers into clinical practice has been restricted by limitations in preparation and application, insufficient pliability, complex product fixation techniques, the need for absolute hemostasis, and incompatibility with laparoscopic surgical procedures [225]. Table 2 summarizes barrier types and reasons why they have shown some efficacy as tissue adhesion barriers. 
Table 2. Materials commonly used in adhesion prevention and a brief description of possible reasons for efficacy in adhesion prevention. Adapted from [10].

\begin{tabular}{|c|c|}
\hline Material & Reasoning for Efficacy \\
\hline Polytetrafluoroethylene (PTFE) & $\begin{array}{c}\text { Physiologically inert } \\
\text { Low adhesiveness with cells / tissues } \\
\text { Separates damaged surfaces during wound healing without degradation } \\
\text { Biocompatible }\end{array}$ \\
\hline Polylactic acid (PLA) & $\begin{array}{c}\text { No specific binding site with cells/tissues on polymer matrix } \\
\text { Low adhesiveness with cells/tissues } \\
\text { Separates damaged surfaces during wound healing without degradation } \\
\text { Biocompatible (FDA approval for human use in orthopedic and } \\
\text { neurosurgical operations) } \\
\text { Biodegradable }\end{array}$ \\
\hline Polyethylene glycol (PEG) & $\begin{array}{l}\text { High mobility and steric stabilization effects in aqueous solution } \\
\text { Low adhesiveness with cells/tissues } \\
\text { Biocompatible }\end{array}$ \\
\hline PLA-PEG & $\begin{array}{l}\text { Low adhesiveness with cells/tissues } \\
\text { Flexible and hydrophilic } \\
\text { Biocompatible } \\
\text { Biodegradable }\end{array}$ \\
\hline
\end{tabular}

Wound healing properties

Hyaluronic Acid (HA)

High viscosity when dissolving by water or body fluid

Muco-adhesive property in solid state

Biocompatible

Bioresorbable

Wound healing properties

Muco-adhesive property in solid state

Alginate (ALG)

Partially crosslinking by multi-valence positive charged ions in body fluid

Biocompatible

Bioresorbable

Wound healing properties, in terms of re-epithelialization

Cellulose (oxidized regenerated) (ORC)

Muco-adhesive property in solid state

Biocompatible

Bioresorbable

Remained on the injury surfaces during wound healing Muco-adhesive property in solid state

Carboxymethyl cellulose (CMC)

Delayed bioresorption

Biocompatible

Metabolized into oligosaccharides by the $\alpha$-amylase in the body

Delayed bioresorption in peritoneal cavity

Icodextrin

Remained on the injury surfaces during wound healing Biocompatible

\subsubsection{Natural Polymers}

Hyaluronic Acid (HA) Based

Barriers containing hyaluronic acid (HA), also referred to as hyaluronan or hyaluronate, are a commonly seen type of adhesion prevention. HA is a naturally occurring glycosaminoglycan and forms a highly viscous solution to coat serosal surfaces. The mechanism by which HA solutions prevent adhesion formation is unknown, but may be due to a cytoprotective effect on mesothelial surfaces [226]. HA solutions have been shown to reduce adhesions following abdominal, orthopedic, and cardiac surgery in animal models [226-230]. Topical administration of HA has been reported to be efficacious in the prevention of post-operative pericardial adhesions in canine and monkey models, and appears to be safe in doses five times the amount required for adhesion prevention [226]. One study showed that applying $0.1 \%$ sodium HA in a canine model caused no clinically significant pericardial 
adhesions compared to $1 \%$ carboxymethyl cellulose, which had $20 \%$ adhesions [231]. In another study, HA was compared to paraffin in preventing intra-peritoneal adhesions in rats and found no significant difference between the two, although the presence of both significantly reduced adhesion formation [232].

As a natural polymer, HA experiences rapid clearance from the applied site due to high blood and body fluid solubility. However, this potential benefit may also lead to reduced efficacy in minimizing post-surgical adhesion formation and is considered a critical hurdle. Cross-linking polymers with chemicals, heat, or light can be a simple strategy to increase their stability in the body. However, loss of specific functional groups in tissue interaction minimizes tissue adhesiveness after cross-linking procedure [233]. Crosslinked HA hydrogel is reported to reduce post-operative adhesion prevention in a mouse uterine horn model [234], whereas a recent human study found the gel to reduce intrauterine adhesion formation [235]. It has been suggested that semi-interpenetrating polymer networks of certain natural polymer combinations can be a solution that compensates for the shared problem of natural polymers [236].

\section{Cellulose Based Barriers}

Carboxymethyl cellulose (CMC) is a cellulose derivative that forms the basis of two commonly used and commercially available adhesion prevention barriers: Interceed (Johnson \& Johnson, Cincinnati, OH, USA) and Seprafilm (Genzyme, Cambridge, MA, USA). Interceed is composed of oxidized regenerated cellulose (ORC), which degrades within 2 weeks after placement [36]. Barriers using ORC are commonly believed to offer an inert and inactive barrier to cellular adhesions, as ORC does not appear to alter the signalling behaviour of mesothelial cells directly [237]. However, Interceed has also been shown to increase expression of tPA in mesothelial cells and increase the tPA:PAI-1 ratio, signifying an overall increase in fibrinolytic activity [238], as well as altering the macrophage immunologic response [239].

Interceed has been studied in animal models in combination with heparin and has been shown to significantly reduce adhesion formation in rabbit uterine horn [240,241] and pericardium [242]. Similarly, other human trials generally find that Interceed reduces the severity, extent, and/or incidence of pelvic adhesions [243-248]. A review of 15 controlled trials in humans reported that Interceed has superior performance compared to Seprafilm in reducing the incidence of adhesion formation [249]. In contrast to these promising results, several murine preclinical models have found no effective prevention of abdominal adhesions [250-253]. A meta-analysis of 7 human studies of nearly 400 patients undergoing laparoscopic pelvic surgery found that the barrier significantly reduced extent and severity of adhesions, but not adhesion incidence [254].

Interceed has several limitations, including that all blood and peritoneal fluid [255] in the abdomen must be cleared before application, while folding or misplacement of Interceed can also induce adhesion formation [256]. Finally, although large clinical studies generally conclude that Interceed is biocompatible and not associated with an increase in adverse events $[249,254]$, the product has been reported to induce a large leukocyte response and stimulate mesothelial cell sloughing in mice [257].

Seprafilm is a commercially-available translucent and temporary adhesion barrier for preventing adhesions. Seprafilm consists of a solid sheet of biodegradable chemicallymodified sodium hyaluronate and carboxymethyl cellulose that physically separates tissue surfaces. It is one of the most studied and implemented anti-adhesion products [258] and has shown efficacy in reducing abdominal adhesions in various animal models [259-271]. Furthermore, Seprafilm has been explored in preclinical studies of pericardial $[229,272-274]$ and pleural adhesions [258]. In a mouse model of redo laparotomy, Seprafilm was found to be effective in preventing adhesions when applied during redo laparotomy and the anti-adhesive effects were most pronounced when applied onto dense adhesions at the time of the redo surgery [275]. 
Randomized, controlled, human trials with greater than 5000 total patients enrolled show that Seprafilm has some efficacy in reducing the incidence, severity, extent, and/or area of abdominal adhesions $[243,255,276-284]$. However, other human studies suggest that Seprafilm only decreases adhesion severity, not incidence [285-287]. A review of 15 randomized controlled trials examining the prevention of pelvic adhesions in female patients reported that Seprafilm had no efficacy in adhesion prevention versus controls [249]. Similarly, studies have failed to consistently confirm the safety of Seprafilm. A meta-analysis of the efficacy and safety of Seprafilm in general surgery patients revealed that abdominal adhesions decreased significantly after use, but it was found to have no effect on postoperative intestinal obstruction and was found to increase abdominal abscesses and anastomotic leaks [288]. Multiple reports also note that Seprafilm is brittle, and suffers from easy adherence to any moist surface, notably surgeons' gloves during operation $[289,290]$. Further, the product cannot easily be affixed to irregularly shaped tissue planes after surgery [275]. Despite these limitations, Seprafilm remains the standard of care in adhesion studies, although few would list it as a definitive solution for the prevention of adhesions [291].

\section{Chitosan Based}

Chitosan is a linear polysaccharide and a common substance found in barrier products. Chitosan-containing barriers are available as a film, gel, or combined with cellulose and seaweed polysaccharides. Several studies demonstrate that chitosan-based products decreased coverage and severity of adhesions in rabbit, porcine, and murine models in cardiac, abdominal, and gynecological surgeries [292-299]. To our knowledge, chitosan itself is yet to be employed in clinical use in humans. Chitosan-based polymers exhibit excellent hemostatic ability, used in commercially available hemostatic products [300]; this characteristic has been leveraged in adhesion prevention. The anti-adhesive mechanism is unclear, but it is hypothesized that it inhibits fibroblast activation and interrupts fibrin matrix formation. Chitosan is most commonly used in combination with other polymers, producing a product known as $\mathrm{N}, \mathrm{O}$-carboxymethyl chitosan.

$\mathrm{N}, \mathrm{O}$-carboxymethyl chitosan has shown efficacy in the reduction of adhesions in the peritoneum and pericardium of rats and rabbits [299,301,302] as well as in patients undergoing pelvic laparoscopy [303]. A similar product, oxidized dextran/N-carboxyethyl chitosan (Odex/CEC) showed significantly decreased adhesion formation in comparison to control in a post-operative abdominal rat model [304]. Novel preparations have used silkworm pupa to generate $\mathrm{N}, \mathrm{O}-\mathrm{Carboxymethyl} \mathrm{chitosan,} \mathrm{which} \mathrm{has} \mathrm{shown} \mathrm{efficacy} \mathrm{in} \mathrm{a}$ rat post-operative peritoneal adhesion model and demonstrated lower levels of TGF- $\beta 1$ expression [305]. A combination polymer barrier, utilizing transglutamine to crosslink carboxymethyl chitosan, carboxymethyl cellulose, and collagen has been found to reduce adhesions in an intra-peritoneal adhesion rat model [306]. This study demonstrated the enhanced mechanical properties and improved biodegradability of the combination polymer, suggesting that biodegradable physical barriers can be more efficacious when incorporated with polymers. Similarly, a combination of N,O-carboxymethyl chitosan/oxidized regenerated cellulose $(\mathrm{N}, \mathrm{O}-\mathrm{CS} / \mathrm{ORC})$ composite gauze has been shown to significantly prevent post-surgical peritoneal adhesions in rats [307], while also serving as an excellent hemostatic agent [306]. This provides an advantage over commercially-available barriers such as Interceed, which is applied only when the entire area is completely hemostatic, an issue that is not trivial in the surgical field.

\section{Natural Films}

REPEL-CV (SyntheMed, Iselin, NJ, USA) is another commercially-available film-based anti-adhesive product that consists of polyethylene glycol and polylactic acid. In cardiothoracic surgeries, REPEL-CV has shown promising results in reducing the formation and severity of post-operative adhesions. These findings have been shown in animal models as well as in human trials of pediatric patients requiring staged sternotomies [308-314]. REPEL-CV received FDA approval for use in pediatric and young adult patients likely 
to need repeat heart surgery. Similar to other barriers, the product provides mechanical separation between opposing tissue surfaces. It has also been suggested that the film acts as a scaffold for tissue regeneration, which ultimately eliminates adhesions [315]. SurgiWrap (MAST Biosurgery USA, Inc. San Diego, CA, USA) is another commercially-available polylatic acid film, which has been associated with significantly reduced incidence and severity of post-operative intra-abdominal adhesions in rat [316] and porcine models of abdominal adhesions [317]. In a human trial, SurgiWrap was associated with reduced peristomal adhesion severity in patients undergoing laparoscopic colorectal cancer surgery [318].

\subsubsection{Synthetic Polymer Meshes}

Non-degradable synthetic polymers have also served as primary forms of barriers against adhesion formation. These include silicone, polyethylene (PE), and expanded polytetrafluorethylene (ePTFE) [10]. Non-degradable polymers require a secondary surgery to remove them, which in itself poses risks of adhesion formation or greater surgical complications due to repeated surgery. Further issues with these mesh polymer barriers include suturing, which was required to affix the barrier due to low adhesiveness with surrounding tissue, and difficulty in application to complex surfaces and in laparoscopic applications due to high flexural rigidity [10].

Gore-Tex (W. L. Gore \& Associates, Newark, NJ, USA) is a commercially-available and commonly used synthetic surgical membrane, composed of non-resorbable expanded polytetrafluorethylene (ePTFE). This inert and permanent barrier acts by preventing cellular growth to prevent adhesion formation [282], and has been used predominantly in pelvic, peritoneal, thoracic, and pericardial surgical applications [256,319-322]. In contrast to other solid barrier products, Gore-Tex must be sutured in place, which can increase adhesion incidence directly and indirectly by prolonging operation time [323]. A 1993 study suggested that Gore-Tex decreased adhesions around the internal mammary artery in a goat model [324]. Further studies using ePTFE have shown some efficacy in adhesion prevention in murine and rabbit models $[253,323,325]$ and a randomized clinical trial examining pelvic adhesions post-myomectomy [326].

Gore-Tex has shown anti-adhesive performance superior to Interceed in mouse and monkey models of pelvic adhesions as well as human studies [249,257,327,328]. There is ongoing debate regarding the lack of removal or absorption of ePFTE, which contributes to long-term safety concerns about the mesh, particularly noting the concerns of an extensive inflammatory reaction resulting in fibrous capsule formation [329]. Studies that do not remove the ePFTE barrier in vascular and pericardial grafts found no significant long-term adverse effects [330], but leaving a foreign body in the surgical field can predispose patients to infections over time [331]. A prospective multi-centre observational study investigating the long-term use of ePTFE without removal reported only one case of post-operative infection, which did not necessitate removal of the membrane [332].

In comparison to polypropylene and polyester, one study found that ePTFE elicits a negligible inflammatory response [55]. However, another study revealed that, due to its non-absorbable nature, ePFTE causes higher rates of inflammation and macroscopic pericardial adhesions compared to a collagen-sponge patch [333]. A study examining polypropylene mesh coated with the commercial product CoSeal (Baxter Healthcare Corp., Deerfield, IL, USA), a re-absorbable hydrogel of polyethylene glycol, has shown superior reduction of adhesion formation in rabbits compared to uncoated meshes [334]. Generally, the literature demonstrates that bioprosthetic meshes have fewer lower-grade adhesions than synthetic mesh [55]. These studies provide evidence that bio-absorbable, natural polymers such as polyvinyl alcohol, polylactic acid, and polyethylene glycol-based biomaterials, are preferable in decreasing adhesion formation. Further studies have been conducted to optimize mesh barriers. One innovative approach that can compensate for the conventional limitations of sheet, mesh, and film type barriers involves the fabrication of barriers with well-organized, porous surfaces that have the capability to absorb blood and body fluids in micropores, thus inducing capillary force $[335,336]$. Another approach 
for addressing drawbacks is the synthesis of copolymers. This strategy involves sourcing monomers with a low glass transition temperature, permitting flexibility of the sheet when at body temperature. These copolymers have demonstrated convenience and positive results in adhesion prevention [337].

Collagen-coating on applied meshes has demonstrated enhanced biocompatibility [338], where intra-peritoneal adhesion formation was reduced at day 7 following the use of a collagen-coated mesh [339]. Meshes and products using collagen have been reported to be highly effective in reducing post-operative abdominal adhesions in animal and human studies [340-343] achieving better clinical efficacy than Interceed [344]. These studies have formed the basis for commercial collagen-based or coated mesh barrier products, which include Alloderm (LifeCell, Branchburg, NJ, USA) [345], Parietex (Covidien, Dublin, Ireland) [346-348], Permacol (Covidien, Dublin, Ireland) [349-351], and Surgisis (Cook Group, Bloomington, IN, USA) [351-354].

\subsubsection{Collagen Sheets}

Collagen sheets are a relatively new form of anti-adhesive barriers. They are bioabsorbable membranes that also act as a scaffold for new cells. In abdominal adhesion models in rats [344] and a rabbit uterine horn abrasion model [355], collagen membranes have been more efficacious than Interceed. Collagen sheets applied to reduce post-operative pericardial adhesions in animal models also resembled native pericardial membranes at 24 weeks post-operation, suggesting a seamless integration [331,356]. A pilot study utilizing a porcine model of pericardial adhesions found fewer macroscopic and microscopic adhesions in all regions after collagen sheet application, although these differences were not statistically significant [357]. COVA (Biom'Up, Lyon, France) is a collagen membrane that has shown feasibility in the prevention of severe pericardial adhesions in pediatric patients undergoing cardiac surgery [358] and in sheep [359]. A recent prospective multicenter study in patients undergoing two-stage abdominal surgeries found that COVA is safe and showed efficacy in reducing post-operative abdominal adhesions [360]. A HA-collagen membrane has also demonstrated efficacy in a rat model of peritoneal adhesions [361]. TachoSil (Nycomed Austria GmbH, Linz, Austria), a hemostatic collagen sponge, has also been found to be superior to Gore-Tex in a rabbit pericardial adhesion model due to its ability to decrease adhesion formation and its scaffolding properties [331,333].

\subsubsection{Composite Polymers}

Composite meshes have shown to decrease visceral adhesions in the chest wall [362] and post-operative adhesions in a rat model [363]. The commercially-available tri-component resorbable mesh, Prevadh (Sofradim Production, Trevoux, France) is composed of polylactic acid, lyophilized porcine collagen, and a hydrophilic collagen film. The product has been effective in preventing intraperitoneal [364] and pleural [365] post-surgical adhesions in rat models. In human trials, Prevadh significantly reduced pelvic adhesion incidence and severity compared to Ringers lactate solution in patients undergoing gynecologic surgery [366]. A prospective multi-center study of patients undergoing both open and laparoscopic general surgery has reported the safety of Prevadh for the prevention of intraperitoneal adhesion formation [367], although a large randomized control trial is yet to be performed.

Composite polymer solutions have some drawbacks, including rapid degradation and unstable biofixation, hence reducing their efficacy $[368,369]$. Another composite copolymer, $\mathrm{D}$, L-polylactide- $\varepsilon$-caprolactonetrimethylenecarbonate, has been shown to decrease adhesions in a post-operative peritoneal rat model, and is suitable for laparoscopic surgery [370], although further validation and investigation is warranted. Current studies have produced more advanced polymeric hydrogels. Stapleton et al. have shown that a dynamically crosslinked supramolecular polymer-nanoparticle hydrogel is superior to Interceed and Seprafilm in reducing the severity of pericardial adhesions in a rat model [371]. 


\subsubsection{Spray Type Barriers}

In efforts to have a barrier that is user friendly, spray-type barrier systems have been developed. In infants undergoing cardiac surgery, a sprayable polymeric matrix has been reported to reduce the incidence and severity of pericardial adhesions [372]. CoSeal Surgical Sealant (Baxter Healthcare, Deerfield, IL, USA), a sprayable synthetic polymeric hydrogel consisting of polyethylene glycol, has been reported to reduce pericardial adhesion severity in rabbits [373] and pediatric patients undergoing repeat heart surgery [372]. A European multicenter study employing the same product reports similar results, however, six adverse events (cardiac fibrillation, pericardial effusion, mediastinitis, supervisor vena cava occlusion, and two cases of cardiac tamponade) were attributed to the product and the study lacks controls [374].

SprayShield (Covidien PLC, Dublin, Ireland) is another polyethylene glycol-based system that has demonstrated anti-adhesive properties in a preclinical porcine model [375] and in a clinical trial of patients undergoing myomectomy [376]. However, another human study found no difference in post-surgical adhesion formation between control and treatment groups [377], although the study has a small sample size and significant confounding factors. A sprayable version of SepraFilm, known as SepraSpray (Genzyme, Cambridge, MA, USA), consists of a powdered form of sodium HA and carboxymethylcellulose. SepraSpray has demonstrated safety and efficacy in preventing abdominal adhesions in rats [378] and in randomized human trials [379,380].

A recently developed spray-type barrier, TCD-11091, was assessed in a randomized, controlled trial of 126 patients undergoing laparotomy, where it was found to reduce the incidence of adhesions [381]. Actamax (Actamax Surgical Materials LLC, Wilmington, DE, USA) is another new sprayable adhesion barrier, which is formed by mixing aqueous dextran aldehyde and polyethylene glycol amine polymers to form a temporary hydrogel. The hydrogel is designed to prevent apposing tissue surfaces from contacting during the immediate post-operative peritoneal healing period ( $3-5$ days) when adhesions are most likely to form [382]. Data from the first in-human randomized control trial suggests the product is safe and effective in reducing post-operative adhesion development, particularly following myomectomy [383]. Although the spray delivery systems facilitate easier use and can incorporate various products, none have been consistently effective in preventing post-operative adhesion formation [384-387].

\subsubsection{Solutions as Barriers}

Irrigating the surgical field using solutions has been believed to aid in preventing or reducing post-surgical adhesion formation. These solutions are typically composed of crystalloids or high-molecular-weight dextran. The use of irrigating solutions is known as hydroflotation, whereby contact between surfaces is reduced to minimize adhesion formation [321]. A meta-analysis of 259 articles examining post-operative adhesion incidence after pelvic surgery concluded that crystalloid irrigation does not reduce adhesion formation [388]. The use of dextran has also been met with conflicting results [389,390]. The high viscosity and long half-life of dextran in the peritoneal cavity also raises concerns regarding potential hemodynamic compromise due to excessive fluid shifts [321].

Adept Adhesion Reduction Solution (Innovata plc, Surrey, UK) is a commerciallyavailable $4 \%$ icodextrin solution made of an $\alpha(1-4)$-linked glucose polymer that acts via hydroflotation. Its intra-peritoneal administration acts as a colloidal osmotic agent, which retains a fluid reservoir within the peritoneal cavity and creates physical separation between peritoneal surfaces. Minimizing surface apposition during the cycle of fibrin deposition and matrix formation has been suggested to reduce adhesion formation [391]. In preclinical animal models, Adept has been promising in reducing the severity and extent of postsurgical adhesion formation [392-394]. Although Adept has been found to be safe [395], similar to other hydroflotation solutions, it has had limited efficacy in randomized clinical trials [391,396,397]. 


\subsubsection{Xenograft Membranes}

Xenograft membranes include equine pericardium, bovine pericardium, and porcine small intestine submucosa. Little has been published regarding their anti-adhesive properties, although these materials have shown early promising results [398,399]. A combined application of acellular bovine pericardium and hyaluronic acid in a rabbit model has shown efficacy in the reduction of postoperative pericardial adhesions [400].

\section{Functional Biomaterials for Adhesion Prevention}

Barrier approaches that employ the use of inert biomaterials have been shown to be effective in animal and human studies. Promisingly, there is a high potential to transform an inert barrier or solution into an effective drug-loaded carrier. Biocompatible polymers have evolved into bioactive and bioinert materials and have been utilized in a variety of biomedical applications such as complex tissue engineering, cell, drug, and gene delivery systems, and organoid formation. A better understanding of the dysregulated tissue healing process that leads to adhesions, current biomaterials can be engineered to be more efficacious in adhesion prevention. Emerging strategies include the incorporation of anti-inflammatory, anti-coagulative, and fibrinolytic agents, as well as growth factors into different types of barriers [7]. Table 3 summarizes the agents and pharmaceuticals that have been used in preclinical and clinical studies along with their indication and findings.

\subsection{Integrated Pharmaceuticals in Barriers}

The use of bioactive barriers offers a unique and compelling approach to preventing post-surgical adhesion formation. Various bio-modifications can be used to transform barriers from inert and inactive walls into active signalling materials that can be instructive to cells, the local environment, and serve as highly localized and effective platforms for drug delivery. However, a detailed analysis of the optimal delivery methods and the choice of which agents to use will be necessary to develop effective integrated pharmaceuticalbarrier products [343].

A thermo-sensitive hydrogel augmented with tPA combined barrier functions with sustained anti-adhesive drug release. In a rat repeated-injury peritoneal adhesion model, the administered tPA-hydrogel successfully promoted mesothelial regeneration on the abdominal wall and decreased PAI-1 levels in peritoneal lavage fluids, leading to decreased fibrin formation [401]. These results indicate the efficacy of targeting the fibrinolytic system in adhesion prevention and the potential to enhance drug delivery via the use of a thermosensitive hydrogel. Lidocaine has recently been shown to have an anti-adhesive effect when loaded onto a poloxamer-alginate-CaCl2 (PACM) barrier in a rat planar incision model [402]. Advanced fabrication methods have allowed for the preparation of a lidocaine-enriched alginate/CMC/polyethylene oxide (PEO) nanofiber film by electrospinning, which facilitated drug release by cross-linking [403]. Although only tested in vitro, this approach demonstrates a promising strategy for the development of sustained drug delivery methods in preventing adhesions.

A thermo-sensitive hydrogel barrier, known as C2.5T1M0.2 thermo-gel, has been developed by combining mitomycin $\mathrm{C}(\mathrm{MMC})$ with modified tempo-oxidized nano-cellulose and methyl cellulose. MMC is a DNA alkylating antitumor antibiotic, which inhibits in vitro fibroblast proliferation with anti-fibrinolytic activity [404]. In a rat model of cecal abrasion, de novo adhesions were effectively prevented and reperitonealization was also observed [405]. The efficacy of this hydrogel can likely be attributed to the combination of a physical barrier with MMC, which is reported to upregulate TNF- $\alpha$, and downregulate collagen and fibronectin gene expression, although the specific cellular effects require elucidation [405]. Similar prevention of pericardial adhesions was seen in a rat model of post-operative adhesions [406]. Another study has also reported the inhibition of peritoneal adhesion formation in a rat model utilizing a novel HA and CMC-sodium cross-linked hydrogel loaded with oxaliplatin, a platinum-containing chemotherapy drug $[407,408]$. The effect of oxaliplatin on adhesion formation has not been fully evaluated, and more 
studies are warranted to delineate the anti-adhesive mechanisms of this hydrogel. Moreover, the co-administration of a HA/CMC barrier material with an NK-1R antagonist in a rat model has demonstrated increased anti-adhesive efficacy at the application site and significantly reduced adhesions at remote sites [409]. Although more detailed investigations are needed, this combination represents an emerging and promising concept in more effectively preventing post-operative adhesion formation throughout the peritoneum.

Ibuprofen, an NSAID, has also been used to augment copolymer films in order to reduce adhesion formation by preventing mass migration of inflammatory cells in a rat peritoneal adhesion model [410]. Ibuprofen has been loaded into electrospun poly(Llactic acid)-polyethylene glycol fibrous membranes, which prevented tissue adhesion and inflammation in a chicken model of tendon adhesions [411]. Electrospun poly(Llactide) (PLLA) and its copolymers have been prepared in combination with various pharmaceuticals, such as the antibacterial beta-lactam cefoxitin sodium [412], the NSAID celecoxib [413], combinations of hemostatic, antibacterial, and antiadhesive agents [414], and others $[415,416]$. Similarly, naproxen has been added to a chitosan hydrogel and shown to prevent post-surgical peritoneal adhesions in a rat model [417]. While the antiadhesive mechanisms of NSAIDs continue to be investigated, this study demonstrates the feasibility of using barrier products to serve as both a drug-delivery platform and as an anti-adhesive therapeutic. However, it is difficult to achieve long-term drug release using current electrospun fibrous membranes of biodegradable polymers because of their large surface area to volume ratio.

\subsection{Nanoparticles and Gene Therapy}

Nanoparticles have been suggested as controlled drug delivery carriers because of their unique physical properties, which include uniform and modifiable particle and pore size; high surface area and large pore volume; and superior biocompatibility [418]. Silver nanoparticles (AgNPs) have been loaded into electrospun fibrous membranes composed of PLLA, where an in vitro study demonstrated that this novel membrane suppressed adhesions and the proliferation of fibroblasts in addition to having antibacterial effects [419]. Ibuprofen has also been integrated into AgNP-PLLA electrospun membrane, which showed enhanced adhesion prevention and anti-proliferation effects in a chicken tendon adhesion model [420]. In a rat model of tendon adhesions, a novel preparation of pre-formulated dextran glassy nanoparticles (DGNs) were loaded with basic fibroblast growth factor (bFGF or FGF-2) [421]. The encapsulation of bFGF into these fine, polysaccharide glassy particles was done to preserve the stability and biological activity of the growth factor. The incorporation of bFGFDGNs into PLLA fibers can serve to control the release of bFGF from this barrier method while leveraging the physical separation capabilities of the polymer. This study highlights the potential to leverage bioactive mediators that have been shown to be dysregulated in postsurgical adhesion formation, such as bFGF, while utilizing the benefits of inert biomaterial barriers. Sustaining the biological activity of bFGF through this method was shown to enhance tendon healing and simultaneously prevent peritendinous adhesion in vivo [421].

Polylactic-co-glycolic acid (PGLA) nanoparticles have also been used to modulate gene expression via sustained gene delivery of TGF- $\beta 1$ mi-RNA plasmids in a chicken tendon adhesion model [422]. By targeting and downregulating TGF- $\beta 1$, this study shows that using a plasmid-nanoparticle method as a non-viral vector for gene therapy can potentially be beneficial in adhesion prevention. Similar studies have demonstrated less severe adhesion grading in the same chicken tendon model upon treatment with PGLATGF- $\beta 1$ mi-RNA RNAi plasmids, although the ultimate strength of tendons repaired with plasmids was significantly lower [423]. Nanoparticles have also been utilized to deliver bFGF and VEGF genes, demonstrating up-regulated protein expression in transfected tenocytes and significantly enhanced healing ability [424]. The use of biologically-active substances loaded into nanoparticle membranes offers a great opportunity to deliver anti-adhesive therapeutics in a targeted and personalized manner, hence addressing the systematic side effect issues of many other agents. 
Table 3. Materials demonstrating efficacy in human or animal models as per clinical indication of anti-adhesion results.

\begin{tabular}{|c|c|c|c|c|}
\hline Type & Material & Company & Model & Reference \\
\hline \multicolumn{5}{|c|}{$\begin{array}{l}\text { Natural Polymers } \\
\text { (biodegradable) }\end{array}$} \\
\hline & Alginate & & Rat (peritoneal) & {$[233,425]$} \\
\hline & HA-mildly crosslinked alginate hydrogel & & Rat (peritoneal) & [426] \\
\hline & Pluronic mixtures/crosslinked alginate & $\begin{array}{l}\text { Guardix-SG } \\
\text { (Genewel) }\end{array}$ & Rat, Rabbit (peritoneal) & {$[427,428]$} \\
\hline & & & Rabbit (pericardial) & [429] \\
\hline & & & Rat (pelvic) & {$[430]$} \\
\hline & HA-crosslinked alginate (powder) & & & [432] \\
\hline & Gelatin & & Rat (peritoneal) & {$[433,434]$} \\
\hline & & & Canine (abdominal) & [435] \\
\hline & & & Canine (pelvic) & [436] \\
\hline & Chitostan-gelatin films & & Rat (peritoneal) & [437] \\
\hline & Gelatin-polyglycolic acid sheets & & Canine (pericardial) & [315] \\
\hline & Genipin-crosslinked gelatin microspheres & & Mouse (peritoneal) & [438] \\
\hline & Gellan Gum & & Rat (peritoneal) & [439] \\
\hline & Poly- $\gamma$-glutamic acid & & Rat (peritoneal) & [440] \\
\hline & Fibrin glue & & Canine (pericardial) & [445] \\
\hline \multicolumn{5}{|c|}{ Hyaluronic Acid (HA) Based } \\
\hline & Auto-crosslinked HA & & Rat (peritoneal) & [446-448] \\
\hline & & & Human (pelvic) & {$[236,449]$} \\
\hline & Crosslinkable HA derivative-alginate & & Rat (peritoneal) & [450] \\
\hline & Phenolic hydroxyl modified HA hydrogel & & Mouse (abdominal) & [451] \\
\hline & HA-adipicdihydrazide-HA-aldehyde & & Rabbit (peritoneal) & [452] \\
\hline & $\begin{array}{l}\text { HA-hydrazide-celluloses-aldehyde [Celluloses: HA, CMC, } \\
\text { hydroxypropylmethylcellulose (HPMC), methylcellulose (MC)] }\end{array}$ & & Mouse (peritoneal) & {$[453]$} \\
\hline & Pullan & & Rat (peritoneal) & [454] \\
\hline \multicolumn{5}{|c|}{ Synthetic Polymers } \\
\hline & Polyethylene glycol (PEG) & & Rat (peritoneal) & [455] \\
\hline & PEG-aliphatic polyester & & Rat, Rabbit (abdominal) & {$[456,457]$} \\
\hline & PEG dicarboxylate-poly(ethylene oxide) hydrogel film & & Rat (abdominal) & [458] \\
\hline & Polylactide-PEG tri-block copolymer (PELA) & & Mouse, Rat (abdominal) & {$[459,460]$} \\
\hline & Poloxamer 407 (PEG-polypropylene glycol-PEG) & FloGel (Alliance Pharm Co.) & Rat, Hamster, Rabbit (peritoneal) & {$[428,461-463]$} \\
\hline
\end{tabular}


Table 3. Cont.

\begin{tabular}{|c|c|c|c|c|}
\hline Type & Material & Company & Model & Reference \\
\hline & PEG-poly $(\alpha$-hydroxy acid $)$ diacrylate macromers & & Rat (peritoneal), Rabbit (pelvic) & [464] \\
\hline & PEG-chitostan & & Rat (peritoneal) & [465] \\
\hline & PEG-poly( $\varepsilon$-caprolactone)-PEG (PECE) hydrogel & & Mouse, Rat (peritoneal) & [466] \\
\hline & Silicone & & Canine (peritoneal) & [467] \\
\hline & Polyethylene & & Rat (peritoneal) & [45] \\
\hline & Poly(vinyl alcohol) (PVA) & & Rabbit (peritoneal) & [468] \\
\hline & & & Rat (pericardial) & [469] \\
\hline & PVA-gelatin membrane & & Rat (peritoneal) & {$[470]$} \\
\hline & PVA hydrogel & & $\begin{array}{l}\text { Porcine, Rat, Human } \\
\text { (peritoneal) }\end{array}$ & [471-473] \\
\hline & & & Rabbit (abdominal) & [474] \\
\hline & PVA-coated polyester mesh & & Rat (peritoneal) & [475] \\
\hline & PVA-CMC hydrogel & & Rabbit (abdominal) & [476] \\
\hline & PVA-CMC trilaminar membrane & & Rabbit (pericardial) & [477] \\
\hline & Polylactic acid (PLA) & & Rat (peritoneal) & {$[270,335,465,478]$} \\
\hline & & & Rabbit, Porcine (pericardial) & {$[314,479]$} \\
\hline & PLA nanosheets & & Mouse (peritoneal) & {$[480]$} \\
\hline & PLA gel & & Human (skin-flap) & [481] \\
\hline & PLA-PEG copolymer membrane & & Rat (Peritoneal, pericardial) & [482] \\
\hline & & & Canine (pericardial) & [483] \\
\hline & PLA-PEG-ePTFE bioresorbable polymer & & Rabbit (pericardial) & [484] \\
\hline & Poly $\varepsilon$-caprolactone (PCLA) & & Rat (abdominal) & {$[485,486]$} \\
\hline & Hyaluronic acid-loaded poly( $\varepsilon$-caprolactone) & & Rat (abominal) & [487] \\
\hline & 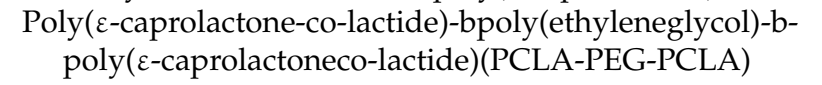 & & Rabbit (peritoneal) & [488] \\
\hline & $\begin{array}{l}\text { Poly(ethylene glycol)-poly ( } \varepsilon \text {-caprolactone)-poly(ethylene } \\
\text { glycol) (PEG-PCLA-PEG, PECE) }\end{array}$ & & Rat (peritoneal) & [489] \\
\hline & 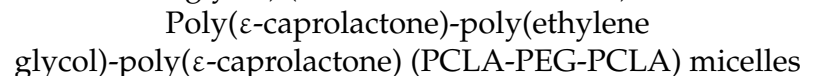 & & Rat (peritoneal) & [490] \\
\hline \multirow{4}{*}{ Composite Polymers } & Poly- $\beta$-hydroxybutyrate & & Bovine, Ovine (pericardial) & {$[491,492]$} \\
\hline & PEG-poly- $\beta$-hydroxybutyrate valerate & & Rat (peritoneal) & [465] \\
\hline & & & & \\
\hline & Polyethylene oxide-sodium carboxymethylcellulose gel & $\begin{array}{l}\text { Oxiplex/AP Gel (FzioMed) } \\
\text { Intercoat (Ethicon) }\end{array}$ & Human (pelvic) & [493-496] \\
\hline
\end{tabular}


Table 3. Cont.

\begin{tabular}{|c|c|c|c|c|}
\hline Type & Material & Company & Model & Reference \\
\hline & & & Rat (peritoneal) & [497] \\
\hline & Silicone-urethane-polyester copolymer & (UBE Sheet, UBE Industries Ltd.) & Canine (pericardial) & [498] \\
\hline & $\begin{array}{c}\text { HA-3,3' -dithiopropionic dihydrazide/PEG diacrylate } \\
\text { (HA-DTPH/PEGDA) }\end{array}$ & $\begin{array}{l}\text { Carbylan-SX (Carbylan } \\
\text { Biosurgery Inc.) }\end{array}$ & $\begin{array}{l}\text { Rat (peritoneal), Rabbit } \\
\text { (pericardial) }\end{array}$ & [499] \\
\hline & & & Rabbit (pericardial) & [500] \\
\hline & Poloxamer-alginate- $\mathrm{CaCl} 2$ (gel) & & Rabbit (pericardial) & [501] \\
\hline & Carboxymethyldextranhydrazide-DX-aldehyde & & Rabbit (peritoneal) & [427] \\
\hline & $\begin{array}{l}\text { Poly(lactic acid)-poly(oxyethylene-cooxypropylene) } \\
\text { (PLA-Pluronic F68) }\end{array}$ & & Rat (peritoneal) & [337] \\
\hline & $\begin{array}{l}\text { D,L-polylactide- } \varepsilon \text {-caprolactonetrimethylenecarbonate (PCT } \\
\text { co-polymer) }\end{array}$ & & Rat (peritoneal) & [370] \\
\hline & Monomethoxy poly(ethylene glycol)-poly(lactic acid) hydrogel & & Rat (abdominal) & [502] \\
\hline & $\begin{array}{l}\text { PLGA-poly(lactide-co-caprolactone) } \\
\text { (PLCA)-poly(L-phenylalanine-co-p-dioxanone (PDPA) film }\end{array}$ & & Rabbit (abdominal) & [503] \\
\hline & $\begin{array}{l}\text { Oxidized regenerated } \\
\text { cellulose-polypropylene-poly( } \varepsilon \text {-caprolactone })\end{array}$ & & Rat (abdominal) & [504] \\
\hline \multicolumn{5}{|c|}{$\begin{array}{c}\text { Drug-Loaded Composite } \\
\text { Polymers } \\
\text { Antibiotics }\end{array}$} \\
\hline & $\begin{array}{c}\text { Cefoxitin sodium in PLGA/PEG-PLA membrane (nanofibrous } \\
\text { sheet) }\end{array}$ & & Rat (peritoneal) & [412] \\
\hline & Ornidazole in PCL (nanofibrous sheet) & & Rat (peritoneal) & [486] \\
\hline & Chloramphenicol in dextran (solution) & & Rat (peritoneal) & [505] \\
\hline \multicolumn{5}{|c|}{ Anti-coagulant (Heparin) } \\
\hline & Heparin in Interceed & & Rabbit, human (peritoneal) & {$[240,506]$} \\
\hline & Heparin in Seprafilm & & Rat (peritoneal) & [507] \\
\hline & Heparin in collagen & & Canine (peritoneal) & [508] \\
\hline \multicolumn{5}{|c|}{ Anti-inflammatory } \\
\hline & Ibuprofen in PLLA-PEG copolymer (dense or nanofibrous sheet) & & Rat (peritoneal) & [410] \\
\hline & Ibuprofen in pluronic mixtures-crosslinked ALG (hydrogel) & & Rat (peritoneal) & [428] \\
\hline & Ibuprofen in poly(lactic-co-glycolic acid) (nanofibrous mesh) & & Mouse (abdominal) & [509] \\
\hline & Ibuprofen in PVA cryobarrier & & Rat (abdominal) & [510] \\
\hline & Dexamethasone in poly(lactide-co-glycolide) microparticles & & Rat (peritoneal) & [511] \\
\hline & Dexamethasone in PLA-PEG copolymer & & Rabbit (pericardial) & [512] \\
\hline
\end{tabular}


Table 3. Cont

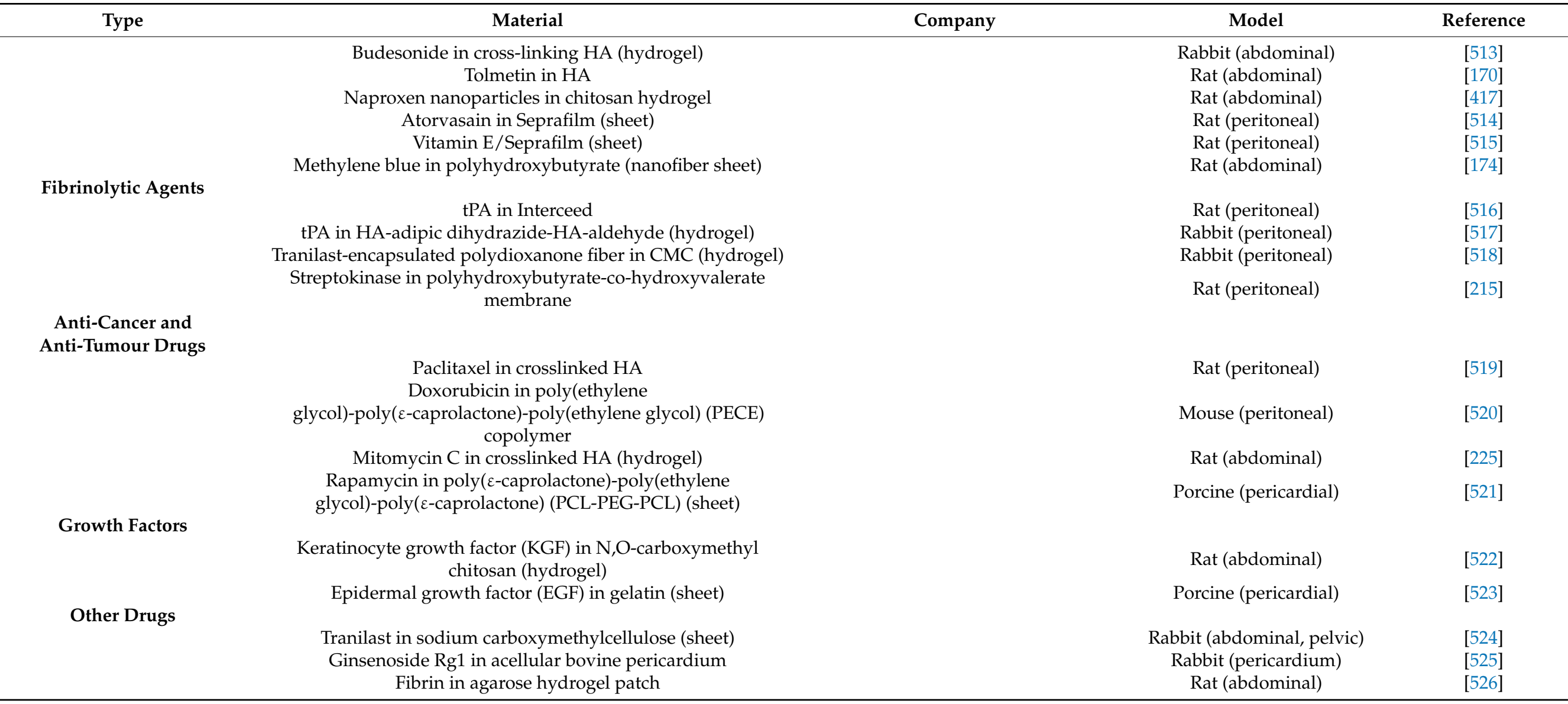




\section{Perspective}

Post-surgical adhesions pose a great health and financial burden. A substantial amount of work has been dedicated to better understanding the exact mechanism of adhesion formation in the surgical setting. Inflammation and immune mediators have long thought to play a central role in the development and severity of post-operative adhesions. Although our knowledge of some of the underlying mechanisms driving adhesion formation has significantly improved over the past two decades, literature has yet to fully explain the pathogenesis and etiology of post-surgical adhesions. As a result, finding an ideal preventative strategy and leveraging appropriate tissue engineering strategies has proven to be difficult.

Primary prevention of post-operative adhesions involves careful and meticulous surgical work causing minimal tissue injury. Some groups believe that this can also be accomplished via laparoscopic surgery as an alternative to open surgery $[527,528]$. However, for select surgeries, there is no substitute for open surgery. Preventing postsurgical adhesion formation is difficult for two main reasons. First, adhesions form as a result of a coordinated physiologic response to tissue injury. Second, the exact mechanisms driving adhesion formation are not well understood. Therefore, preventative measures that have been proposed to date have not been completely and consistently successful once translated into clinical settings. In some cases, they have led to serious adverse events, including infection and irreversible disruption of the physiologic healing process. Unfortunately, experimental animal models often produce results that are far superior to those seen in human clinical trials, rendering preclinical results not reproducible. For these reasons, although a large number of preventative and therapeutic options have been developed, their clinical translation has generally been limited.

As reviewed here, pharmaceutical agents and different barrier strategies have been used to varying degrees of success in preventing or minimizing post-operative adhesions. Drugs that target either inflammatory pathways or components of the clotting cascade have been used, but their clinical success has been limited due to systemic effects or inhibition of normal healing processes. Barriers, which range from natural to synthetic to a mixture of both, have been designed to create frictionless surfaces between tissue layers. The clinical application of these products has been restricted for different reasons, such as requiring a dry, bloodless surface and challenges with placing a barrier in irregularly-shaped areas.

The development of successful biomaterials for post-surgical adhesion will likely need to employ an understanding of the surface characteristics of these biomaterials in addition to a deepened understanding of the physiological mechanisms behind adhesion formation. Future biomaterials will likely have multiple favorable characteristics through the use of a mixture of natural and synthetic polymers, copolymers, use of novel preparation methods, and by leveraging the drug loading capabilities of biomaterials. The design of pharmaceuticals and barriers will have to focus on the promotion of wound healing, hemostatic, and even regenerative capacities of biomaterials, while leveraging anti-adhesive properties of currently established barrier methods [7]. Multifunctional or multi-layer biomaterials that can employ a variety of anti-adhesive and regenerative strategies with different structural compositions can build on the advantages of copolymers. These strategies will set the foundation for the design of systems that can incorporate stem cells to promote and induce tissue regeneration. Moreover, further customization for each tissue cavity can be possible, leading to the restoration of tissue function, promoting fibrinolysis, and reducing friction through lubrication [529]. It is also feasible to augment these multilayered structures with multiple drugs to leverage their effects on specific components of adhesion formation pathways, or the incorporation of immune moieties for the regulation of the immune system to promote healing [529]. The role of nanoparticles and gene therapy in preventing post-surgical adhesions should also be meticulously assessed. These emerging strategies are promising in theory and potentially offer an ideal platform for facilitating precision and personalized medicine. Ultimately, any potential strategy must be safe, effective, user-friendly, have a readily-accessible delivery method, and ideally, be biodegradable. 
Furthermore, more robust basic and pre-clinical studies are needed. In addition to considering different tissue planes and cavities, such studies should carefully assess the safety and efficacy of preventative measures for various types of surgeries and the delivery options available to surgeons. Finally, to establish clinical relevance, current and future agents must be evaluated in rigorous, large, multicenter, randomized, controlled trials that include patients undergoing different types of surgery.

\section{Conclusions}

Post-surgical adhesions are fibrotic connections that form between organ surfaces and the walls of surrounding body cavities following tissue trauma and ischemia. To varying degrees of success, different strategies have been employed to mitigate the challenges associated with post-surgical adhesions. Herein, we have summarized established methods and products that have been used in pre-clinical and clinical studies. We have also examined emerging approaches that have the potential to facilitate precision medicine in mitigating post-surgical adhesions.

Funding: This research received no external funding.

Conflicts of Interest: The authors declare no conflict of interest.

\section{References}

1. Diamond, M.P.; Freeman, M.L. Clinical implications of postsurgical adhesions. Hum. Reprod. Update 2001, 7, 567-576. [CrossRef] [PubMed]

2. Lauder, C.I.; Garcea, G.; Strickland, A.; Maddern, G.J. Abdominal Adhesion Prevention: Still a Sticky Subject. Dig. Surg. 2010, 27, 347-358. [CrossRef]

3. Weibel, M.-A.; Majno, G. Peritoneal adhesions and their relation to abdominal surgery: A postmortem study. Am. J. Surg. 1973, 126, 345-353. [CrossRef]

4. Menzies, D.; Ellis, H. Intestinal obstruction from adhesions-How big is the problem? Ann. R. Coll. Surg. Engl. 1990, 72, 60-63.

5. Arung, W.; Meurisse, M.; Detry, O. Pathophysiology and prevention of postoperative peritoneal adhesions. World J. Gastroenterol. 2011, 17, 4545-4553. [CrossRef]

6. Capella-Monsonís, H.; Kearns, S.; Kelly, J.; Zeugolis, D.I. Battling adhesions: From understanding to prevention. BMC Biomed. Eng. 2019, 1, 1-12. [CrossRef]

7. Park, H.; Baek, S.; Kang, H.; Lee, D. Biomaterials to Prevent Post-Operative Adhesion. Materials 2020, 13, 3056. [CrossRef]

8. Thakur, M.; Rambhatla, A.; Qadri, F.; Chatzicharalampous, C.; Awonuga, M.; Saed, G.; Diamond, M.P.; Awonuga, A.O. Is There a Genetic Predisposition to Postoperative Adhesion Development? Reprod. Sci. 2020. [CrossRef]

9. Strik, C.; Wever, K.E.; Stommel, M.W.J.; Van Goor, H.; Broek, R.P.G.T. Adhesion reformation and the limited translational value of experiments with adhesion barriers: A systematic review and meta-analysis of animal models. Sci. Rep. 2019, 9, 1-10. [CrossRef]

10. Lih, E.; Oh, S.H.; Joung, Y.K.; Lee, J.H.; Han, D.K. Polymers for cell/tissue anti-adhesion. Prog. Polym. Sci. 2015, 44, 28-61. [CrossRef]

11. Fortin, C.N.; Saed, G.M.; Diamond, M. Predisposing factors to post-operative adhesion development. Hum. Reprod. Update 2015, 21, 536-551. [CrossRef] [PubMed]

12. Sikirica, V.; Bapat, B.; Candrilli, S.D.; Davis, K.L.; Wilson, M.; Johns, A. The inpatient burden of abdominal and gynecological adhesiolysis in the US. BMC Surg. 2011, 11, 13. [CrossRef] [PubMed]

13. Coleman, M.G.; McLain, A.D.; Moran, B.J. Impact of previous surgery on time taken for incision and division of adhesions during laparotomy. Dis. Colon Rectum 2000, 43, 1297-1299. [CrossRef] [PubMed]

14. Broek, R.P.T.; Issa, Y.; van Santbrink, E.J.; Bouvy, N.D.; Kruitwagen, R.F.; Jeekel, J.; Bakkum, E.; Rovers, M.; Van Goor, H. Burden of adhesions in abdominal and pelvic surgery: Systematic review and metanalysis. BMJ 2013, 347, f5588. [CrossRef]

15. Lower, A.M.; Hawthorn, R.J.; Ellis, H.; O’Brien, F.; Buchan, S.; Crowe, A.M. The impact of adhesions on hospital readmissions over ten years after 8849 open gynaecological operations: An assessment from the Surgical and Clinical Adhesions Research Study. BJOG Int. J. Obstet. Gynaecol. 2000, 107, 855-862. [CrossRef]

16. Nkere, U.U. Postoperative Adhesion Formation and the Use of Adhesion Preventing Techniques in Cardiac and General Surgery. ASAIO J. 2000, 46, 654-656. [CrossRef]

17. Nkere, U.U.; Whawell, S.A.; Sarraf, C.E.; Schofield, J.B.; Thompson, J.N.; Taylor, K.M. Pericardial Trauma and Adhesions in Relation to Reoperative Cardiac Surgery. Thorac. Cardiovasc. Surg. 1995, 43, 338-346. [CrossRef]

18. Ellis, H.; Moran, B.J.; Thompson, J.N.; Parker, M.C.; Wilson, M.S.; Menzies, D.; McGuire, A.; Lower, A.M.; Hawthorn, R.J.; O’Brien, F.; et al. Adhesion-related hospital readmissions after abdominal and pelvic surgery: A retrospective cohort study. Lancet 1999, 353, 1476-1480. [CrossRef] 
19. Parker, M.C.; Wilson, M.S.; Menzies, D.; Sunderland, G.; Clark, D.; Knight, A.D.; Crowe, A.M. The SCAR-3 study: 5-year adhesion-related readmission risk following lower abdominal surgical procedures. Color. Dis. 2005, 7, 551-558. [CrossRef]

20. Parker, M.C.; Ellis, H.; Moran, B.J.; Thompson, J.N.; Wilson, M.S.; Menzies, D.; McGuire, A.; Lower, A.M.; Hawthorn, R.J.; O'Briena, F.; et al. Postoperative adhesions: Ten-year follow-up of 12,584 patients undergoing lower abdominal surgery. Dis. Colon Rectum 2001, 44, 822-829. [CrossRef]

21. Ray, N.F.; Denton, W.G.; Thamer, M.; Henderson, S.C.; Perry, S. Abdominal adhesiolysis: Inpatient care and expenditures in the United States in 1994. J. Am. Coll. Surg. 1998, 186, 1-9. [CrossRef]

22. Broek, R.P.T.; Bakkum, E.A.; Laarhoven, C.J.; van Goor, H. Epidemiology and Prevention of Postsurgical Adhesions Revisited. Ann. Surg. 2016, 263, 12-19. [CrossRef]

23. Liakakos, T.; Thomakos, N.; Fine, P.M.; Dervenis, C.; Young, R.L. Peritoneal Adhesions: Etiology, Pathophysiology, and Clinical Significance. Dig. Surg. 2001, 18, 260-273. [CrossRef]

24. Goel, G.; King, T.; Daveson, A.J.; Andrews, J.M.; Krishnarajah, J.; Krause, R.; Brown, G.J.E.; Fogel, R.; Barish, C.F.; Epstein, R.; et al. Epitope-specific immunotherapy targeting CD4-positive T cells in coeliac disease: Two randomised, double-blind, placebo-controlled phase 1 studies. Lancet Gastroenterol. Hepatol. 2017, 2, 479-493. [CrossRef]

25. Herrick, S.E.; Mutsaers, S.E.; Ozua, P.; Sulaiman, H.; Omer, A.; Boulos, P.; Foster, M.L.; Laurent, G.J. Human peritoneal adhesions are highly cellular, innervated, and vascularized. J. Pathol. 2000, 192, 67-72. [CrossRef]

26. Arjmand, M.-H. The association between visceral adiposity with systemic inflammation, oxidative stress, and risk of post-surgical adhesion. Arch. Physiol. Biochem. 2020, 2020, 1-6. [CrossRef] [PubMed]

27. Pismensky, S.V.; Kalzhanov, Z.R.; Eliseeva, M.Y.; Kosmas, I.P.; Mynbaev, O.A. Severe inflammatory reaction induced by peritoneal trauma is the key driving mechanism of postoperative adhesion formation. BMC Surg. 2011, 11, 30. [CrossRef] [PubMed]

28. Sun, Z.; Sessler, D.I.; Dalton, J.E.; Devereaux, P.J.; Shahinyan, A.; Naylor, A.J.; Hutcherson, M.T.; Finnegan, P.S.; Tandon, V.; Darvish-Kazem, S.; et al. Postoperative Hypoxemia is Common and Persistent: A Prospective Blinded Observational Study. Anesth. Analg. 2015, 121, 709-715. [CrossRef] [PubMed]

29. Coccolini, F.; Ansaloni, L.; Manfredi, R.; Campanati, L.; Poiasina, E.; Bertoli, P.; Capponi, M.G.; Sartelli, M.; Di Saverio, S.; Cucchi, M.; et al. Peritoneal adhesion index (PAI): Proposal of a score for the "ignored iceberg" of medicine and surgery. World J. Emerg. Surg. 2013, 8, 6. [CrossRef] [PubMed]

30. Binda, M.M.; Molinas, C.R.; Koninckx, P.R. Reactive oxygen species and adhesion formation: Clinical implications in adhesion prevention. Hum. Reprod. 2003, 18, 2503-2507. [CrossRef]

31. Risberg, B.; Stenberg, B. Modulation of tissue fibrinolysis from hypoxia and hyperoxia. Thromb. Res. 1985, 38, 129-136. [CrossRef]

32. Yan, S.-F.; Mackman, N.; Kisiel, W.; Stern, D.M.; Pinsky, D.J. Hypoxia/Hypoxemia-Induced Activation of the Procoagulant Pathways and the Pathogenesis of Ischemia-Associated Thrombosis. Arter. Thromb. Vasc. Biol. 1999, 19, 2029-2035. [CrossRef]

33. Gertler, J.P.; Perry, L.; L'Italien, G.; Chung-Welch, N.; Cambria, R.P.; Orkin, R.; Abbott, W.M. Ambient oxygen tension modulates endothelial fibrinolysis. J. Vasc. Surg. 1993, 18, 939-946. [CrossRef]

34. Di Zerega, G.S. Biochemical events in peritoneal tissue repair. Eur. J. Surg. Suppl. 1997, 577, 10-16.

35. Chegini, N. Peritoneal molecular environment, adhesion formation and clinical implication. Front. Biosci. 2002,7 , e91-e115.

36. Boland, G.M.; Weigel, R. Formation and Prevention of Postoperative Abdominal Adhesions. J. Surg. Res. 2006, 132, 3-12. [CrossRef]

37. Holmdahl, L.; Eriksson, E.; Al-Jabreen, M.; Risberg, B. Fibrinolysis in human peritoneum during operation. Surgery 1996, 119, 701-705. [CrossRef]

38. Holmdahl, L.; Ivarsson, M.L. The role of cytokines, coagulation, and fibrinolysis in peritoneal tissue repair. Eur. J. Surg. Suppl. 1999, 165, 1012-1019.

39. Hellebrekers, B.W.J.; Kooistra, T. Pathogenesis of postoperative adhesion formation. BJS 2011, 98, 1503-1516. [CrossRef] [PubMed]

40. Foster, D.S.; Marshall, C.D.; Gulati, G.S.; Chinta, M.S.; Nguyen, A.; Salhotra, A.; Jones, R.E.; Burcham, A.; Lerbs, T.; Cui, L.; et al. Elucidating the fundamental fibrotic processes driving abdominal adhesion formation. Nat. Commun. 2020, 11, 1-18. [CrossRef] [PubMed]

41. Xu, X.; Rivkind, A.; Pappo, O.; Pikarsky, A.; Levi-Schaffer, F. Role of Mast Cells and Myofibroblasts in Human Peritoneal Adhesion Formation. Ann. Surg. 2002, 236, 593-601. [CrossRef]

42. Cannata, A.; Petrella, D.; Russo, C.F.; Bruschi, G.; Fratto, P.; Gambacorta, M.; Martinelli, L. Postsurgical Intrapericardial Adhesions: Mechanisms of Formation and Prevention. Ann. Thorac. Surg. 2013, 95, 1818-1826. [CrossRef]

43. Park, D.S.; Regmi, S.C.; Svystonyuk, D.A.; Teng, G.; Belke, D.; Turnbull, J.; Guzzardi, D.G.; Kang, S.; Cowman, M.K.; Schmidt, T.A.; et al. Human pericardial proteoglycan 4 (lubricin): Implications for postcardiotomy intrathoracic adhesion formation. $J$. Thorac. Cardiovasc. Surg. 2018, 156, 1598-1608.e1. [CrossRef]

44. Di Zerega, G.S.; Campeau, J.D. Peritoneal repair and post-surgical adhesion formation. Hum. Reprod. Update 2001, 7, 547-555. [CrossRef]

45. Ellis, H.; Harrison, W.; Hugh, T.B. The healing of the peritoneum under normal and pathological conditions. Br. J. Surg. 1965, 52, 471-476. [CrossRef]

46. Raftery, A.T. Regeneration of parietal and visceral peritoneum: An electron microscopical study. J. Anat. 1973, 115, 375-392.

47. Cheong, Y.C.; Laird, S.M.; Li, T.C.; Shelton, J.B.; Ledger, W.L.; Cooke, I.D. Peritoneal healing and adhesion formation/reformation. Hum. Reprod. Update 2001, 7, 556-566. [CrossRef] [PubMed] 
48. Lucas, P.; Warejcka, D.J.; Young, H.E.; Lee, B.Y. Formation of Abdominal Adhesions Is Inhibited by Antibodies to Transforming Growth Factor- $\beta 1$. J. Surg. Res. 1996, 65, 135-138. [CrossRef]

49. Mutsaers, S.E.; Birnie, K.; Lansley, S.; Herrick, S.E.; Lim, C.-B.; Prêle, C.M. Mesothelial cells in tissue repair and fibrosis. Front. Pharmacol. 2015, 6, 113. [CrossRef] [PubMed]

50. Tsai, J.M.; Shoham, M.; Fernhoff, N.B.; George, B.M.; Marjon, K.D.; McCracken, M.N.; Kao, K.S.; Sinha, R.; Volkmer, A.K.; Miyanishi, M.; et al. Neutrophil and monocyte kinetics play critical roles in mouse peritoneal adhesion formation. Blood Adv. 2019, 3, 2713-2721. [CrossRef] [PubMed]

51. Sandoval, P.; Jiménez-Heffernan, J.A.; Guerra-Azcona, G.; Pérez-Lozano, M.L.; Rynne-Vidal, A.; Albar-Vizcaíno, P.; Gil-Vera, F.; Martín, P.; Coronado, M.J.; Barcena, C.; et al. Mesothelial-to-mesenchymal transition in the pathogenesis of post-surgical peritoneal adhesions. J. Pathol. 2016, 239, 48-59. [CrossRef]

52. Wallach, E.E.; Holtz, G. Prevention and management of peritoneal adhesions. Fertil. Steril. 1984, 41, 497-507. [CrossRef]

53. Tsai, J.M.; Sinha, R.; Seita, J.; Fernhoff, N.; Christ, S.; Koopmans, T.; Krampitz, G.W.; McKenna, K.; Xing, L.; Sandholzer, M.; et al. Surgical adhesions in mice are derived from mesothelial cells and can be targeted by antibodies against mesothelial markers. Sci. Transl. Med. 2018, 10, eaan6735. [CrossRef] [PubMed]

54. Binnebösel, M.; Rosch, R.; Junge, K.; Lynen-Jansen, P.; Schumpelick, V.; Klinge, U. Macrophage and T-lymphocyte Infiltrates in Human Peritoneal Adhesions Indicate a Chronic Inflammatory Disease. World J. Surg. 2007, 32, 296-304. [CrossRef]

55. Turza, K.C.; Butler, C.E. Adhesions and meshes: Synthetic versus bioprosthetic. Plast. Reconstr. Surg. 2012, 130, 206s-213s. [CrossRef] [PubMed]

56. Ergül, E.; Korukluoglu, B. Peritoneal adhesions: Facing the enemy. Int. J. Surg. 2008, 6, 253-260. [CrossRef]

57. Cantürk, N.Z.; Vural, B.; Esen, N.; Cantürk, Z.; Oktay, G.; Kirkali, G.; Solakoglu, S. Effects of granulocyte-macrophage colonystimulating factor on incisional wound healing in an experimental diabetic rat model. Endocr. Res. 1999, 25, 105-116. [CrossRef]

58. Menzies, D. Peritoneal adhesions. Incidence, cause, and prevention. Surg. Annu. 1992, 24, $27-45$.

59. Ar'Rajab, A.; Dawidson, I.; Sentementes, J.; Sikes, P.; Harris, R.; Mileski, W. Enhancement of Peritoneal Macrophages Reduces Postoperative Peritoneal Adhesion Formation. J. Surg. Res. 1995, 58, 307-312. [CrossRef] [PubMed]

60. Rodgers, K.E.; Dizerega, G.S. Modulation of peritoneal re-epithelialization by postsurgical macrophages. J. Surg. Res. 1992, 53, 542-548. [CrossRef]

61. Raftery, A.T. Regeneration of parietal and visceral peritoneum in the immature animal: A light and electron microscopical study. Br. J. Surg. 2005, 60, 969-975. [CrossRef]

62. Arfors, K.E.; Lundberg, C.; Lindbom, L.; Lundberg, K.; Beatty, P.G.; Harlan, J.M. A monoclonal antibody to the membrane glycoprotein complex CD18 inhibits polymorphonuclear leukocyte accumulation and plasma leakage in vivo. Blood 1987, 69, 338-340. [CrossRef]

63. Ar'Rajab, A.; Mileski, W.; Sentementes, J.T.; Sikes, P.; Harris, R.B.; Dawidson, I.J. The Role of Neutrophils in Peritoneal Adhesion Formation. J. Surg. Res. 1996, 61, 143-146. [CrossRef]

64. Raa, S.; van den Tol, M.P.; Sluiter, W.; Hofland, L.J.; van Eijck, C.H.; Jeekel, H. The role of neutrophils and oxygen free radicals in post-operative adhesions. J. Surg. Res. 2006, 136, 45-52. [PubMed]

65. Chung, D.R.; Chitnis, T.; Panzo, R.J.; Kasper, D.L.; Sayegh, M.H.; Tzianabos, A.O. CD4+ T Cells Regulate Surgical and Postinfectious Adhesion Formation. J. Exp. Med. 2002, 195, 1471-1478. [CrossRef] [PubMed]

66. Tzianabos, A.O.; Holsti, M.A.; Zheng, X.X.; Stucchi, A.F.; Kuchroo, V.K.; Strom, T.B.; Glimcher, L.H.; Cruikshank, W.W. Functional Th1 cells are required for surgical adhesion formation in a murine model. J. Immunol. 2008, 180, 6970-6976. [CrossRef] [PubMed]

67. Ozbilgin, K.; Üner, M.A.; Ozkut, M.; Hasdemir, P.S. The effects of pirfenidone on T helper cells in prevention of intraperitoneal adhesions. Kaohsiung J. Med. Sci. 2017, 33, 271-276. [CrossRef] [PubMed]

68. Cantürk, N.Z.; Vural, B.; Cubukcu, A.; Duzcen, E.; Utkan, Z.; Dülger, M. Experimental study on the role of mast cells in peritoneal adhesion formation. East Afr. Med. J. 1999, 76, 233-236.

69. Yao, Y.-L.; Ishihara, T.; Takai, S.; Miyazaki, M.; Mita, S. Association between the Expression of Mast Cell Chymase and Intraperitoneal Adhesion Formation in Mice. J. Surg. Res. 2000, 92, 40-44. [CrossRef]

70. Cahill, R.A.; Wang, J.H.; Soohkai, S.; Redmond, H.P. Mast cells facilitate local VEGF release as an early event in the pathogenesis of postoperative peritoneal adhesions. Surgery 2006, 140, 108-112. [CrossRef]

71. Palta, S.; Saroa, R.; Palta, A. Overview of the coagulation system. Indian J. Anaesth. 2014, 58, 515-523. [CrossRef]

72. Holmdahl, L. The role of fibrinolysis in adhesion formation. Eur. J. Surg. Suppl. 1997, 577, $24-31$.

73. Cheong, Y.C.; Shelton, J.B.; Laird, S.M.; Li, T.C.; Ledger, W.L.; Cooke, I.D. Peritoneal fluid concentrations of matrix metalloproteinase-9, tissue inhibitor of metalloproteinase-1, and transforming growth factor-beta in women with pelvic adhesions. Fertil. Steril. 2003, 79, 1168-1175. [CrossRef]

74. Chegini, N.; Kotseos, K.; Bennett, B.; Diamond, M.; Holmdahl, L.; Burns, J. Matrix metalloproteinase (MMP-1) and tissue inhibitor of MMP in peritoneal fluids and sera and correlation with peritoneal adhesions. Fertil. Steril. 2001, 76, 1207-1211. [CrossRef]

75. Chegini, N.; Kotseos, K.; Zhao, Y.; Ma, C.; McLean, F.; Diamond, M.; Holmdahl, L.; Burns, J. Expression of matrix metalloproteinase (MMP-1) and tissue inhibitor of MMP in serosal tissue of intraperitoneal organs and adhesions. Fertil. Steril. 2001, 76, 1212-1219. [CrossRef] 
76. Christodoulidis, G.; Tsilioni, I.; Spyridakis, M.-E.; Kiropoulos, T.; Oikonomidi, S.; Koukoulis, G.; Tepetes, K. Matrix Metaloproteinase-2 and -9 Serum Levels as Potential Markers of Intraperitoneal Adhesions. J. Investig. Surg. 2013, 26, 134-140. [CrossRef]

77. Chegini, N.; Zhao, Y.; Kotseos, K.; Ma, C.; Bennett, B.; Diamond, M.P.; Holmdahl, L.; Skinner, K. Differential expression of matrix metalloproteinase and tissue inhibitor of MMP in serosal tissue of intraperitoneal organs and adhesions. BJOG Int. J. Obstet. Gynaecol. 2002, 109, 1041-1049. [CrossRef]

78. Buyalos, R.P.; Funari, V.A.; Azziz, R.; Watson, J.M.; Martinez-Maza, O. Elevated interleukin-6 levels in peritoneal fluid of patients with pelvic pathology. Fertil. Steril. 1992, 58, 302-306. [CrossRef]

79. Kaidi, A.A.; Gurchumelidze, T.; Nazzal, M.; Figert, P.; Vanterpool, C.; Silva, Y. Tumor Necrosis Factor- $\alpha$ : A Marker for Peritoneal Adhesion Formation. J. Surg. Res. 1995, 58, 516-518. [CrossRef]

80. Cheong, Y.; Laird, S.; Shelton, J.; Ledger, W.; Li, T.C.; Cooke, I. The correlation of adhesions and peritoneal fluid cytokine concentrations: A pilot study. Hum. Reprod. 2002, 17, 1039-1045. [CrossRef]

81. Cheong, Y.C.; Shelton, J.B.; Laird, S.M.; Richmond, M.; Kudesia, G.; Li, T.C.; Ledger, W.L. IL-1, IL-6 and TNF- $\alpha$ concentrations in the peritoneal fluid of women with pelvic adhesions. Hum. Reprod. 2002, 17, 69-75. [CrossRef]

82. Wang, G.; Wu, K.; Li, W.; Zhao, E.; Shi, L.; Wang, J.; Shuai, X.; Cai, K.; Lu, X.; Tao, K.; et al. Role of IL-17 and TGF-beta in peritoneal adhesion formation after surgical trauma. Wound Repair Regen. 2014, 22, 631-639. [CrossRef] [PubMed]

83. Saed, G.M.; Zhang, W.; Diamond, M.P. Molecular characterization of fibroblasts isolated from human peritoneum and adhesions. Fertil. Steril. 2001, 75, 763-768. [CrossRef]

84. Tsukada, K.; Katoh, H.; Suzuki, T.; Takenoshita, S.; Nagamachi, Y. Correlations of peritoneal interleukin-6, serum beta-2 microglobulin and urinary beta-2 microglobulin after elective abdominal surgery. APMIS 1993, 101, 409-412. [CrossRef] [PubMed]

85. Yoshikawa, H.; Kawamura, I.; Fujita, M.; Tsukada, H.; Arakawa, M.; Mitsuyama, M. Membrane damage and interleukin-1 production in murine macrophages exposed to listeriolysin O. Infect. Immun. 1993, 61, 1334-1339. [CrossRef] [PubMed]

86. Whawell, S.A.; Wang, Y.; Fleming, K.A.; Thompson, E.M.; Thompson, J.N. Localization of plasminogen activator inhibitor-1 production in inflamed appendix byin situ mRNA hybridization. J. Pathol. 1993, 169, 67-71. [CrossRef] [PubMed]

87. Betjes, M.G.; Tuk, C.W.; Struijk, D.G.; Krediet, R.T.; Arisz, L.; Hart, M.; Beelen, R.H. Interleukin-8 production by human peritoneal mesothelial cells in response to tumor necrosis factor-alpha, interleukin-1, and medium conditioned by macrophages cocultured with Staphylococcus epidermidis. J. Infect. Dis. 1993, 168, 1202-1210. [CrossRef]

88. Kaidi, A.A.; Nazzal, M.; Gurchumelidze, T.; Ali, M.; Dawe, E.J.; Silva, Y.J. Preoperative administration of antibodies against tumor necrosis factor-alpha (TNF-alpha) and interleukin-1 (IL-1) and their impact on peritoneal adhesion formation. Am. Surg. 1995, 61, 569-572.

89. Williams, R.; Rossi, A.M.; Chegini, N.; Schultz, G. Effect of transforming growth factor $\beta$ on postoperative adhesion formation and intact peritoneum. J. Surg. Res. 1992, 52, 65-70. [CrossRef]

90. Chegini, N. The role of growth factors in peritoneal healing: Transforming growth factor beta (TGF-beta). Eur. J. Surg. Suppl. Acta Chir. Suppl. 1997, 1997, 17-23.

91. Chegini, N. TGF-beta system: The principal profibrotic mediator of peritoneal adhesion formation. Semin. Reprod. Med. 2008, 26, 298-312. [CrossRef] [PubMed]

92. Holmdahl, L.; Kotseos, K.; Bergström, M.; Falk, P.; Ivarsson, M.L.; Chegini, N. Overproduction of transforming growth factorbeta1 (TGF-beta1) is associated with adhesion formation and peritoneal fibrinolytic impairment. Surgery 2001, 129, 626-632. [CrossRef] [PubMed]

93. Hobson, K.G.; Dewing, M.; Ho, H.S.; Wolfe, B.M.; Cho, K.; Greenhalgh, D.G. Expression of Transforming Growth Factor $\beta 1$ in Patients with and without Previous Abdominal Surgery. Arch. Surg. 2003, 138, 1249-1252. [CrossRef]

94. Chegini, N.; Kotseos, K.; Zhao, Y.; Bennett, B.; McLean, F.W.; Diamond, M.P.; Holmdahl, L.; Burns, J. Differential expression of TGF- $\beta 1$ and TGF- $\beta 3$ in serosal tissues of human intraperitoneal organs and peritoneal adhesions. Hum. Reprod. 2001, 16, 1291-1300. [CrossRef] [PubMed]

95. Cahill, R.A.; Redmond, H.P. Cytokine orchestration in post-operative peritoneal adhesion formation. World J. Gastroenterol. 2008, 14, 4861-4866. [CrossRef]

96. Imudia, A.N.; Kumar, S.; Saed, G.M.; Diamond, M.P. Pathogenesis of Intra-abdominal and Pelvic Adhesion Development. Semin. Reprod. Med. 2008, 26, 289-297. [CrossRef] [PubMed]

97. Molinas, C.R.; Binda, M.M.; Koninckx, P.R. Angiogenic factors in peritoneal adhesion formation. Gynecol. Surg. 2006, 3, 157-167. [CrossRef]

98. Sutton, C. Adhesions following surgery: Pathogenesis and current experience with adhesion barriers. Surg. Technol. Int. 2009, 18, $144-156$.

99. Lundorff, P.; Hahlin, M.; Källfelt, B.; Thorburn, J.; Lindblom, B. Adhesion formation after laparoscopic surgery in tubal pregnancy: A randomized trial versus laparotomy. Fertil. Steril. 1991, 55, 911-915. [CrossRef]

100. Schäfer, M.; Krähenbühl, L.; Büchler, M. Comparison of Adhesion Formation in Open and Laparoscopic Surgery. Dig. Surg. 1998, 15, 148-152. [CrossRef]

101. Ten Broek, R.P.; Kok-Krant, N.; Bakkum, E.A.; Bleichrodt, R.P.; van Goor, H. Different surgical techniques to reduce post-operative adhesion formation: A systematic review and meta-analysis. Hum. Reprod. Update 2013, 19, 12-25. [CrossRef] 
102. Tittel, A.; Treutner, K.; Titkova, S.; Öttinger, A.; Schumpelick, V. Comparison of adhesion reformation after laparoscopic and conventional adhesiolysis in an animal model. Langenbeck's Arch. Surg. 2001, 386, 141-145. [CrossRef] [PubMed]

103. Nagle, A.; Ujiki, M.; Denham, W.; Murayama, K. Laparoscopic adhesiolysis for small bowel obstruction. Am. J. Surg. 2004, 187, 464-470. [CrossRef]

104. Tabibian, N.; Swehli, E.; Boyd, A.; Umbreen, A.; Tabibian, J. Abdominal adhesions: A practical review of an often overlooked entity. Ann. Med. Surg. 2017, 15, 9-13. [CrossRef]

105. De Souza, A.M.; Wang, C.C.; Chu, C.Y.; Lam, P.M.; Rogers, M.S. The effect of intra-abdominal pressure on the generation of 8-iso prostaglandin F2alpha during laparoscopy in rabbits. Hum. Reprod. 2003, 18, 2181-2188. [CrossRef] [PubMed]

106. Bulletti, C.; Polli, V.; Negrini, V.; Giacomucci, E.; Flamigni, C. Adhesion formation after laparoscopic myomectomy. J. Am. Assoc. Gynecol. Laparoscopists 1996, 3, 533-536. [CrossRef]

107. Alpay, Z.; Saed, G.; Diamond, M. Postoperative Adhesions: From Formation to Prevention. Semin. Reprod. Med. 2008, 26, 313-321. [CrossRef]

108. Ott, D.E. Laparoscopy and Tribology: The Effect of Laparoscopic Gas on Peritoneal Fluid. J. Am. Assoc. Gynecol. Laparoscopists 2001, 8, 117-123. [CrossRef]

109. Molinas, C.R.; Mynbaev, O.; Pauwels, A.; Novak, P.; Koninckx, P.R. Peritoneal mesothelial hypoxia during pneumoperitoneum is a cofactor in adhesion formation in a laparoscopic mouse model. Fertil. Steril. 2001, 76, 560-567. [CrossRef]

110. Binda, M.; Molinas, C.; Mailova, K.; Koninckx, P. Effect of temperature upon adhesion formation in a laparoscopic mouse model. Hum. Reprod. 2004, 19, 2626-2632. [CrossRef] [PubMed]

111. Mais, V. Peritoneal adhesions after laparoscopic gastrointestinal surgery. World J. Gastroenterol. 2014, 20, 4917-4925. [CrossRef]

112. Diamond, M.P. Reduction of postoperative adhesion development. Fertil. Steril. 2016, 106, 994-997. [CrossRef]

113. Ferrario, C.M.; Strawn, W.B. Role of the Renin-Angiotensin-Aldosterone System and Proinflammatory Mediators in Cardiovascular Disease. Am. J. Cardiol. 2006, 98, 121-128. [CrossRef]

114. Weber, K.T.; Brilla, C.G. Pathological hypertrophy and cardiac interstitium. Fibrosis and renin-angiotensin-aldosterone system. Circulation 1991, 83, 1849-1865. [CrossRef]

115. Brilla, C.G. Renin-angiotensin-aldosterone system and myocardial fibrosis. Cardiovasc. Res. 2000, 47, 1-3. [CrossRef]

116. Pereira, R.M.; Dos Santos, R.A.S.; Dias, F.L.D.C.; Teixeira, M.M.; Silva, A.C.S.E. Renin-angiotensin system in the pathogenesis of liver fibrosis. World J. Gastroenterol. 2009, 15, 2579-2586. [CrossRef] [PubMed]

117. Wynn, T. Cellular and molecular mechanisms of fibrosis. J. Pathol. 2007, 214, 199-210. [CrossRef] [PubMed]

118. Schnee, J.M.; Hsueh, W. Angiotensin II, adhesion, and cardiac fibrosis. Cardiovasc. Res. 2000, 46, 264-268. [CrossRef]

119. Nakamoto, H.; Imai, H.; Fukushima, R.; Ishida, Y.; Yamanouchi, Y.; Suzuki, H. Role of the renin-angiotensin system in the pathogenesis of peritoneal fibrosis. Perit. Dial. Int. 2008, 28, 83-87. [CrossRef]

120. Oparil, S.; Haber, E. The renin-angiotensin system (first of two parts). N. Engl. J. Med. 1974, 291, 389-401. [CrossRef] [PubMed]

121. Jia, G.; Aroor, A.R.; Hill, M.; Sowers, J.R. Role of Renin-Angiotensin-Aldosterone System Activation in Promoting Cardiovascular Fibrosis and Stiffness. Hypertension 2018, 72, 537-548. [CrossRef]

122. Ruiz-Ortega, M.; Rupérez, M.; Esteban, V.; Rodriguez-Vita, J.; Sánchez-López, E.; Carvajal, G.; Egido, J. Angiotensin II: A key factor in the inflammatory and fibrotic response in kidney diseases. Nephrol. Dial. Transplant. 2006, 21, 16-20. [CrossRef]

123. Vaughan, D.E. Angiotensin and vascular fibrinolytic balance. Am. J. Hypertens. 2002, 15, S3-S8. [CrossRef]

124. Ghosh, A.K.; Vaughan, D.E. PAI-1 in tissue fibrosis. J. Cell. Physiol. 2012, 227, 493-507. [CrossRef]

125. Koh, K.K.; Chung, W.-J.; Ahn, J.Y.; Han, S.H.; Kang, W.C.; Seo, Y.-H.; Ahn, T.H.; Choi, I.S.; Shin, E.K. Angiotensin II type 1 receptor blockers reduce tissue factor activity and plasminogen activator inhibitor type-1 antigen in hypertensive patients: A randomized, double-blind, placebo-controlled study. Atherosclerosis 2004, 177, 155-160. [CrossRef] [PubMed]

126. Tokinaga, Y.; Kimoto, Y.; Ogawa, K.; Mizumoto, K.; Tange, K.; Hatano, Y. Reduction of adhesion formation by an angiotensin type 1 receptor antagonist. Langenbeck's Arch. Surg. 2010, 396, 127-132. [CrossRef] [PubMed]

127. Wang, Y.; Del Borgo, M.; Lee, H.W.; Baraldi, D.; Hirmiz, B.; Gaspari, T.A.; Denton, K.M.; Aguilar, M.-I.; Samuel, C.S.; Widdop, R.E. Anti-fibrotic Potential of AT2 Receptor Agonists. Front. Pharmacol. 2017, 8, 564. [CrossRef] [PubMed]

128. Rehman, A.; Leibowitz, A.; Yamamoto, N.; Rautureau, Y.; Paradis, P.; Schiffrin, E.L. Angiotensin Type 2 Receptor Agonist Compound 21 Reduces Vascular Injury and Myocardial Fibrosis in Stroke-Prone Spontaneously Hypertensive Rats. Hypertension 2012, 59, 291-299. [CrossRef] [PubMed]

129. Lange, C.; Sommerfeld, M.; Namsolleck, P.; Kintscher, U.; Unger, T.; Kaschina, E. AT 2 R (Angiotensin AT2 Receptor) Agonist, Compound 21, Prevents Abdominal Aortic Aneurysm Progression in the Rat. Hypertension 2018, 72, e20-e29. [CrossRef]

130. Koulis, C.; Chow, B.S.; McKelvey, M.; Steckelings, U.M.; Unger, T.; Thallas-Bonke, V.; Thomas, M.C.; Cooper, M.E.; Jandeleit-Dahm, K.A.; Allen, T.J. AT2R Agonist, Compound 21, Is Reno-Protective Against Type 1 Diabetic Nephropathy. Hypertension 2015, 65, 1073-1081. [CrossRef]

131. Rathinasabapathy, A.; Horowitz, A.; Horton, K.; Kumar, A.; Gladson, S.; Unger, T.; Martinez, D.; Bedse, G.; West, J.; Raizada, M.K.; et al. The Selective Angiotensin II Type 2 Receptor Agonist, Compound 21, Attenuates the Progression of Lung Fibrosis and Pulmonary Hypertension in an Experimental Model of Bleomycin-Induced Lung Injury. Front. Physiol. 2018, 9, 180. [CrossRef] [PubMed]

132. Boudreau, C.; LeVatte, T.; Jones, C.; Gareau, A.; Legere, S.; Bezuhly, M. The Selective Angiotensin II Type 2 Receptor Agonist Compound 21 Reduces Abdominal Adhesions in Mice. J. Surg. Res. 2020, 256, 231-242. [CrossRef] 
133. Bülbüller, N.; Ilhan, Y.S.; Kirkil, C.; Çetiner, M.; Gogebakan, Ö.; Ilhan, N. Can Angiotensin Converting Enzyme Inhibitors Prevent Postoperative Adhesions? J. Surg. Res. 2005, 125, 94-97. [CrossRef] [PubMed]

134. Ilhan, Y.S.; Bülbüller, N.; Kirkil, C.; Ozercan, R.; Seckin, D. The Effect of an Angiotensin Converting Enzyme Inhibitor on Intestinal Wound Healing. J. Surg. Res. 2005, 128, 61-65. [CrossRef]

135. Noh, H.; Ha, H.; Yu, M.R.; Kim, Y.O.; Kim, J.H.; Lee, H.B. Angiotensin II mediates high glucose-induced TGF-beta1 and fibronectin upregulation in HPMC through reactive oxygen species. Perit. Dial. Int. 2005, 25, 38-47. [CrossRef]

136. Awonuga, A.O.; Belotte, J.; Abuanzeh, S.; Fletcher, N.M.; Diamond, M.P.; Saed, G.M. Advances in the Pathogenesis of Adhesion Development: The Role of Oxidative Stress. Reprod. Sci. 2014, 21, 823-836. [CrossRef]

137. Strowitzki, M.J.; Ritter, A.S.; Radhakrishnan, P.; Harnoss, J.M.; Opitz, V.M.; Biller, M.; Wehrmann, J.; Keppler, U.; Scheer, J.; Wallwiener, M.; et al. Pharmacological HIF-inhibition attenuates postoperative adhesion formation. Sci. Rep. 2017, 7, 1-14. [CrossRef]

138. Lu, R.-M.; Hwang, Y.-C.; Liu, I.-J.; Lee, C.-C.; Tsai, H.-Z.; Li, H.-J.; Wu, H.-C. Development of therapeutic antibodies for the treatment of diseases. J. Biomed. Sci. 2020, 27, 1-30. [CrossRef]

139. Colak, N.; Nazli, Y.; Alpay, M.F.; Aksoy, O.N.; Akkaya, I.O.; Bayrak, R.; Cakir, O. Effect of topical N-acetylcysteine in the prevention of postoperative pericardial adhesion formation in a rabbit model. Cardiovasc. Pathol. 2013, 22, 368-372. [CrossRef] [PubMed]

140. Chu, D.I.; Lim, R.; Heydrick, S.; Gainsbury, M.L.; Abdou, R.; D’Addese, L.; Reed, K.L.; Stucchi, A.F.; Becker, J.M. N-acetyl-1cysteine decreases intra-abdominal adhesion formation through the upregulation of peritoneal fibrinolytic activity and antioxidant defenses. Surgery 2011, 149, 801-812. [CrossRef] [PubMed]

141. Haslinger, B.; Goedde, M.F.; Toet, K.H.; Kooistra, T. Simvastatin increases fibrinolytic activity in human peritoneal mesothelial cells independent of cholesterol lowering. Kidney Int. 2002, 62, 1611-1619. [CrossRef] [PubMed]

142. Hoscan, Y.; Karabulut, Z.; Hoscan, M.; Arikan, S.; Ögüs, E.; Muderrisoglu, I.H.; Hoscan, Y.; Karabulut, Z.; Hoscan, M.; Arikan, S.; et al. Oral fluvastatin reduces the severity of peritoneal adhesions in rats. Acta Chir. Belg. 2010, 110, 66-70. [CrossRef] [PubMed]

143. Yue, Y.; Yan, S.; Li, H.; Zong, Y.; Yue, J.; Zeng, L. The role of oral fluvastatin on postoperative peritoneal adhesion formation in an experimental rat model. Acta Chir. Belg. 2018, 118, 372-379. [CrossRef] [PubMed]

144. Aarons, C.B.; Cohen, P.A.; Gower, A.; Reed, K.L.; Leeman, S.E.; Stucchi, A.F.; Becker, J.M. Statins (HMG-CoA reductase inhibitors) decrease postoperative adhesions by increasing peritoneal fibrinolytic activity. Ann. Surg. 2007, 245, 176-184. [CrossRef]

145. Reed, K.L.; Stucchi, A.F.; Leeman, S.E.; Becker, J.M. Inhibitory Effects of a Neurokinin-1 Receptor Antagonist on Postoperative Peritoneal Adhesion Formation. Ann. N. Y. Acad. Sci. 2008, 1144, 116-126. [CrossRef]

146. Reed, K.L.; Heydrick, S.J.; Aarons, C.B.; Prushik, S.; Gower, A.C.; Stucchi, A.F.; Becker, J.M. A neurokinin-1 receptor antagonist that reduces intra-abdominal adhesion formation decreases oxidative stress in the peritoneum. Am. J. Physiol. Liver Physiol. 2007, 293, G544-G551. [CrossRef] [PubMed]

147. Prushik, S.G.; Aarons, C.B.; Matteotti, R.; Reed, K.L.; Gower, A.C.; Leeman, S.E.; Stucchi, A.F.; Becker, J.M. A neurokinin 1 receptor antagonist decreases adhesion reformation after laparoscopic lysis of adhesions in a rat model of adhesion formation. Surg. Endosc. 2007, 21, 1790-1795. [CrossRef]

148. Cohen, P.A.; Gower, A.C.; Stucchi, A.F.; Leeman, S.E.; Becker, J.M.; Reed, K.L. A neurokinin-1 receptor antagonist that reduces intraabdominal adhesion formation increases peritoneal matrix metalloproteinase activity. Wound Repair Regen. 2007, 15, 800-808. [CrossRef]

149. Lim, R.; Morrill, J.M.; Prushik, S.G.; Reed, K.L.; Gower, A.C.; Leeman, S.E.; Stucchi, A.F.; Becker, J.M. An FDA Approved Neurokinin-1 Receptor Antagonist is Effective in Reducing Intraabdominal Adhesions when Administered Intraperitoneally, But Not Orally. J. Gastrointest. Surg. 2008, 12, 1754-1761. [CrossRef]

150. Cohen, P.A.; Reed, K.L.; Gower, A.C.; Stucchi, A.F.; Lehrmann, J.; Fruin, A.; Leeman, S.E.; Becker, J.M. A substance P receptor antagonist (SPRA) that reduces intraabdominal adhesion formation decreases peritoneal matrix metalloproteinase (MMP) activity. J. Am. Coll. Surg. 2004, 199, 21-22. [CrossRef]

151. Jay, G.D.; Torres, J.R.; Warman, M.L.; Laderer, M.C.; Breuer, K.S. The role of lubricin in the mechanical behavior of synovial fluid. Proc. Natl. Acad. Sci. USA 2007, 104, 6194-6199. [CrossRef] [PubMed]

152. Bielory, L.; Wagle, P. Ocular surface lubricants. Curr. Opin. Allergy Clin. Immunol. 2017, 17, 382-389. [CrossRef]

153. Das, N.; Schmidt, T.A.; Krawetz, R.J.; Dufour, A. Proteoglycan 4: From Mere Lubricant to Regulator of Tissue Homeostasis and Inflammation: Does proteoglycan 4 have the ability to buffer the inflammatory response? Bioessays 2019, 41, e1800166. [CrossRef]

154. Wulff, B.C.; Wilgus, T.A. Mast cell activity in the healing wound: More than meets the eye? Exp. Dermatol. 2013, 22, 507-510. [CrossRef]

155. Overed-Sayer, C.; Rapley, L.; Mustelin, T.; Clarke, D.L. Are mast cells instrumental for fibrotic diseases? Front. Pharmacol. 2014, 4, 174. [CrossRef]

156. Soga, Y.; Takai, S.; Koyama, T.; Okamoto, Y.; Ikeda, T.; Nishimura, K.; Miyazaki, M.; Komeda, M. Attenuation of adhesion formation after cardiac surgery with a chymase inhibitor in a hamster model. J. Thorac. Cardiovasc. Surg. 2004, 127, 72-78. [CrossRef]

157. Soga, Y.; Takai, S.; Koyama, T.; Okamoto, Y.; Ikeda, T.; Nishimura, K.; Miyazaki, M.; Komeda, M. Attenuating Effects of Chymase Inhibitor on Pericardial Adhesion Following Cardiac Surgery. J. Card. Surg. 2007, 22, 343-347. [CrossRef] [PubMed] 
158. Ozeki, M.; Jin, D.; Miyaoka, Y.; Masubuchi, S.; Hirokawa, F.; Hayashi, M.; Takai, S.; Uchiyama, K. Comparison of a chymase inhibitor and hyaluronic acid/carboxymethylcellulose (Seprafilm) in a novel peritoneal adhesion model in rats. PLoS ONE 2019, 14, e0211391. [CrossRef] [PubMed]

159. Okamoto, Y.; Takai, S.; Yamada, M.; Miyazaki, M. Chymase inhibitors may prevent postoperative adhesion formation. Fertil. Steril. 2002, 77, 1044-1048. [CrossRef]

160. Okamoto, Y.; Takai, S.; Miyazaki, M. Significance of chymase inhibition for prevention of adhesion formation. Eur. J. Pharmacol. 2004, 484, 357-359. [CrossRef] [PubMed]

161. Okamoto, Y.; Takai, S.; Miyazaki, M. Effect of Chymase-Dependent Transforming Growth Factor $\beta$ on Peritoneal Adhesion Formation in a Rat Model. Surg. Today 2004, 34, 865-867. [CrossRef] [PubMed]

162. Okamoto, Y.; Takai, S.; Miyazaki, M. Chymase Inhibitor, BCEAB, Suppressed Peritoneal Adhesion Formation in Hamster. J. Surg. Res. 2002, 107, 219-222. [CrossRef] [PubMed]

163. Küçüközkan, T.; Ersoy, B.; Uygur, D.; Gundogdu, C. Prevention of adhesions by sodium chromoglycate, dexamethasone, saline and aprotinin after pelvic surgery. ANZ J. Surg. 2004, 74, 1111-1115. [CrossRef]

164. Rodgers, K.; Girgis, W.; Dizerega, G.S.; Johns, D.B. Intraperitoneal tolmetin prevents postsurgical adhesion formation in rabbits. Int. J. Fertil. 1990, 35, 40-45. [PubMed]

165. Jarrett, J.C.; Dawood, M.Y. Adhesion formation and uterine tube healing in the rabbit: A controlled study of the effect of ibuprofen and flurbiprofen. Am. J. Obstet. Gynecol. 1986, 155, 1186-1192. [CrossRef]

166. De Leon, F.D.; Toledo, A.A.; Sanfilippo, J.S.; Yussman, M.A. The prevention of adhesion formation by nonsteroidal antiinflammatory drugs: An animal study comparing ibuprofen and indomethacin. Fertil. Steril. 1984, 41, 639-642. [CrossRef]

167. Montz, F.J.; Monk, B.J.; Lacy, S.M.; Fowler, J.M.; Montz, F.J.; Monk, B.J.; Lacy, S.M.; Fowler, J.M. Ketorolac tromethamine, a nonsteroidal anti-inflammatory drug: Ability to inhibit post-radical pelvic surgery adhesions in a porcine model. Gynecol. Oncol. 1993, 48, 76-79. [CrossRef]

168. Orita, H.; Girgis, W.; Dizerega, G.S. Prevention of postsurgical peritoneal adhesion formation by intraperitoneal administration of ibuprofen. Drug Dev. Res. 1987, 10, 97-105. [CrossRef]

169. Muzii, L.; Marana, R.; Brunetti, L.; Margutti, F.; Vacca, M.; Mancuso, S. Postoperative adhesion prevention with low-dose aspirin: Effect through the selective inhibition of thromboxane production. Hum. Reprod. 1998, 13, 1486-1489. [CrossRef]

170. Rodgers, K.E.; Johns, D.B.; Girgis, W.; Dizerega, G.S. Prevention of Adhesion Formation with Intraperitoneal Administration of Tolmetin and Hyaluronic Acid. J. Investig. Surg. 1997, 10, 367-373. [CrossRef]

171. Aldemir, M.; Öztürk, H.; Büyükbayram, H.; Erten, G. The Preventive Effect of Rofecoxib in Postoperative Intraperitoneal Adhesions. Acta Chir. Belg. 2004, 104, 97-100. [CrossRef] [PubMed]

172. Nishimura, K.; Nakamura, R.M.; Dizerega, G.S. Ibuprofen inhibition of postsurgical adhesion formation: A time and dose response biochemical evaluation in rabbits. J. Surg. Res. 1984, 36, 115-124. [CrossRef]

173. Golan, A.; Maymon, R.; Winograd, I.; Bukovsky, I. Prevention of post-surgical adhesion formation using aspirin in a rodent model: A preliminary report. Hum. Reprod. 1995, 10, 1797-1800. [CrossRef]

174. Maghsoudi, H.; Askary, B. The effect of piroxicam on the formation of postoperative, intraabdominal adhesion in rats. Saudi J. Gastroenterol. 2008, 14, 198-201. [CrossRef] [PubMed]

175. Tan, V.; Nourbakhsh, A.; Capo, J.; Cottrell, J.A.; Meyenhofer, M.; O'Connor, J.P. Effects of Nonsteroidal Anti-Inflammatory Drugs on Flexor Tendon Adhesion. J. Hand Surg. 2010, 35, 941-947. [CrossRef] [PubMed]

176. Rodgers, K.E.; Girgis, W.; Amand, K.S.; Campeau, J.D.; Dizerega, G.S. Reduction of Adhesion Formation by Intraperitoneal Administration of Various Anti-Inflammatory Agents. J. Investig. Surg. 1998, 11, 327-339. [CrossRef] [PubMed]

177. Alizzi, A.M.; Summers, P.; Boon, V.H.; Tantiongco, J.P.; Thompson, T.; Leslie, B.J.; Williams, D.; Steele, M.; Bidstrup, B.P.; Diqer, A.M. Reduction of post-surgical pericardial adhesions using a pig model. Heart Lung Circ. 2012, 21, 22-29. [CrossRef]

178. Tarhan, O.R.; Barut, I.; Sutcu, R.; Akdeniz, Y.; Akturk, O. Pentoxifylline, a Methyl Xanthine Derivative, Reduces Peritoneal Adhesions and Increases Peritoneal Fibrinolysis in Rats. Tohoku J. Exp. Med. 2006, 209, 249-255. [CrossRef]

179. Greene, A.K.; Alwayn, I.P.J.; Nose, V.; Flynn, E.; Sampson, D.; Zurakowski, D.; Folkman, J.; Puder, M. Prevention of Intraabdominal Adhesions Using the Antiangiogenic COX-2 Inhibitor Celecoxib. Ann. Surg. 2005, 242, 140-146. [CrossRef]

180. Ezberci, F.; Bulbuloglu, E.; Ciragil, P.; Gül, M.; Kurutas, E.B.; Bozkurt, S.; Kale, I.T. Intraperitoneal Tenoxicam to Prevent Abdominal Adhesion Formation in a Rat Peritonitis Model. Surg. Today 2006, 36, 361-366. [CrossRef]

181. Guvenal, T.; Cetin, A.; Ozdemir, H.; Yanar, O.; Kaya, T. Prevention of postoperative adhesion formation in rat uterine horn model by nimesulide: A selective COX-2 inhibitor. Hum. Reprod. 2001, 16, 1732-1735. [CrossRef]

182. Kim, Y.I. Comparative Study for Preventive Effects of Intra-Abdominal Adhesion Using Cyclo-Oxygenase-2 Enzyme (COX-2) Inhibitor, Low Molecular Weight Heparin (LMWH), and Synthetic Barrier. Yonsei Med. J. 2013, 54, 1491-1497. [CrossRef]

183. Gómez, G.G.V.; Linares-Rivera, E.; Tena-Betancourt, E.; Castillo, G.A.D.; Reipen, L. Prevention of postoperative abdominal adhesions using systemic enoxaparin and local diclofenac. An experimental study. Surg. Pract. 2020, 24, 4-10. [CrossRef]

184. LeGrand, E.; Rodgers, K.E.; Girgis, W.; Campeau, J.D.; Dizerega, G.S. Comparative Efficacy of Nonsteroidal Anti-Inflammatory Drugs and Anti-Thromboxane Agents in a Rabbit Adhesion-Prevention Model. J. Investig. Surg. 1995, 8, 187-194. [CrossRef]

185. James, D.S. The multisystem adverse effects of NSAID therapy. J. Am. Osteopat. Assoc. 1999, 99, S1-S7. [CrossRef]

186. Vonkeman, H.E.; van de Laar, M.A. Nonsteroidal anti-inflammatory drugs: Adverse effects and their prevention. Semin. Arthritis Rheum 2010, 39, 294-312. [CrossRef] [PubMed] 
187. Morgan, A.; Clark, D. CNS Adverse Effects of Nonsteroidal Anti-Inflammatory Drugs: Therapeutic Implications. CNS Drugs 1998, 9, 281-290. [CrossRef]

188. Ng, S.C.; Chan, F.K. NSAID-induced gastrointestinal and cardiovascular injury. Curr. Opin. Gastroenterol. 2010, 26, 611-617. [CrossRef]

189. Velo, G.P.; Milanino, R. Nongastrointestinal adverse reactions to NSAID. J. Rheumatol. Suppl. 1990, 20, 42-45. [PubMed]

190. Bhala, N.; Emberson, J.; Merhi, A.; Abramson, S.; Arber, N.; Baron, J.; Bombardier, C.; Cannon, C.; Farkouh, M.; Fitzgerald, G.; et al. Vascular and upper gastrointestinal effects of non-steroidal anti-inflammatory drugs: Meta-analyses of individual participant data from randomised trials. Lancet 2013, 382, 769-779. [CrossRef] [PubMed]

191. Schneider, V.; Lévesque, L.E.; Zhang, B.; Hutchinson, T.; Brophy, J.M. Association of Selective and Conventional Nonsteroidal Antiinflammatory Drugs with Acute Renal Failure: A Population-based, Nested Case-Control Analysis. Am. J. Epidemiol. 2006, 164, 881-889. [CrossRef]

192. Elmadhun, N.Y.; Sabe, A.A.; Lassaletta, A.D.; Dalal, R.S.; Sellke, F.W. Effects of Alcohol on Postoperative Adhesion Formation in Ischemic Myocardium and Pericardium. Ann. Thorac. Surg. 2017, 104, 545-552. [CrossRef] [PubMed]

193. Lassaletta, A.D.; Chu, L.M.; Sellke, F.W. Effects of alcohol on pericardial adhesion formation in hypercholesterolemic swine. J. Thorac. Cardiovasc. Surg. 2012, 143, 953-959. [CrossRef] [PubMed]

194. Cho, M.; Kopp, J.B. Pirfenidone: An anti-fibrotic therapy for progressive kidney disease. Expert Opin. Investig. Drugs 2010, 19, 275-283. [CrossRef] [PubMed]

195. Bayhan, Z.; Zeren, S.; Kocak, F.E.; Kocak, C.; Akcılar, R.; Karg1, E.; Tiryaki, C.; Yaylak, F.; Akc1lar, A. Antiadhesive and antiinflammatory effects of pirfenidone in postoperative intra-abdominal adhesion in an experimental rat model. J. Surg. Res. 2016, 201, 348-355. [CrossRef] [PubMed]

196. Fischer, A.; Koopmans, T.; Ramesh, P.; Christ, S.; Strunz, M.; Wannemacher, J.; Aichler, M.; Feuchtinger, A.; Walch, A.; Ansari, M.; et al. Post-surgical adhesions are triggered by calcium-dependent membrane bridges between mesothelial surfaces. Nat. Commun. 2020, 11, 1-15. [CrossRef] [PubMed]

197. Macarak, E.J.; Lotto, C.E.; Koganti, D.; Jin, X.; Wermuth, P.; Olsson, A.-K.; Montgomery, M.; Rosenbloom, J. Trametinib prevents mesothelial-mesenchymal transition and ameliorates abdominal adhesion formation. J. Surg. Res. 2018, 227, 198-210. [CrossRef]

198. Kohan, M.; Muro, A.F.; White, E.S.; Berkman, N. EDA-containing cellular fibronectin induces fibroblast differentiation through binding to alpha4beta7 integrin receptor and MAPK/Erk 1/2-dependent signaling. FASEB J. 2010, 24, 4503-4512. [CrossRef]

199. Fang, C.-C.; Chou, T.-H.; Huang, J.-W.; Lee, C.-C.; Chen, S.-C. The Small Molecule Inhibitor QLT-0267 Decreases the Production of Fibrin-Induced Inflammatory Cytokines and Prevents Post-Surgical Peritoneal Adhesions. Sci. Rep. 2018, 8, 1-12. [CrossRef]

200. Ye, N.; Ding, Y.; Wild, C.; Shen, Q.; Zhou, J. Small Molecule Inhibitors Targeting Activator Protein 1 (AP-1). J. Med. Chem. 2014, 57, 6930-6948. [CrossRef]

201. Grow, D.R.; Coddington, C.C.; Hsiu, J.-G.; Mikich, Y.; Hodgen, G.D. Role of hypoestrogenism or sex steroid antagonism in adhesion formation after myometrial surgery in primates**Prize Paper, The Society of Reproductive Surgeons. In Proceedings of the 50th Annual Meeting of The American Fertility Society, San Antonio, TX, USA, 5-10 November 1994.

202. Bozkurt, S.; Yuzbasioglu, M.F.; Bulbuloglu, E.; Gul, M.; Kale, I.T. Prevention of Postoperative Peritoneal Adhesions by Administration of Estrogen. J. Investig. Surg. 2009, 22, 263-267. [CrossRef] [PubMed]

203. Johary, J.; Xue, M.; Zhu, X.; Xu, D.; Velu, P.P. Efficacy of Estrogen Therapy in Patients with Intrauterine Adhesions: Systematic Review. J. Minim. Invasive Gynecol. 2014, 21, 44-54. [CrossRef] [PubMed]

204. Baatar, D.; Patel, K.; Taub, D.D. The effects of ghrelin on inflammation and the immune system. Mol. Cell. Endocrinol. 2011, 340, 44-58. [CrossRef] [PubMed]

205. Bianchi, E.; Boekelheide, K.; Sigman, M.; Lamb, D.J.; Hall, S.J.; Hwang, K. Ghrelin ameliorates adhesions in a postsurgical mouse model. J. Surg. Res. 2016, 201, 226-234. [CrossRef] [PubMed]

206. Bianchi, E.; Boekelheide, K.; Sigman, M.; Lamb, D.J.; Hall, S.J.; Hwang, K. Ghrelin Inhibits Post-Operative Adhesions via Blockage of the TGF- $\beta$ Signaling Pathway. PLoS ONE 2016, 11, e0153968. [CrossRef]

207. Yeo, Y.; Kohane, D.S. Polymers in the prevention of peritoneal adhesions. Eur. J. Pharm. Biopharm. 2008, 68, 57-66. [CrossRef]

208. Iskesen, I.; Aksoy, O.; Cerrahoglu, M.; Sirin, H. The effect of piroxicam on the prevention of postoperative retrosternal and pericardial adhesions. Acta Cardiol. 2007, 62, 559-564. [CrossRef]

209. Berkkanoglu, M.; Zhang, L.; Ulukus, M.; Cakmak, H.; Kayisli, U.A.; Kursun, S.; Arici, A. Inhibition of chemokines prevents intraperitoneal adhesions in mice. Hum. Reprod. 2005, 20, 3047-3052. [CrossRef]

210. Lu, J.-H.; Chang, Y.; Sung, H.-W.; Chiu, Y.-T.; Yang, P.-C.; Hwang, B. Heparinization on pericardial substitutes can reduce adhesion and epicardial inflammation in the dog. J. Thorac. Cardiovasc. Surg. 1998, 115, 1111-1120. [CrossRef]

211. Wiseman, D.M.; Kamp, L.; Linsky, C.B.; Jochen, R.F.; Pang, R.H.; Scholz, P.M. Fibrinolytic drugs prevent pericardial adhesions in the rabbit. J. Surg. Res. 1992, 53, 362-368. [CrossRef]

212. Saeidi, M.; Movahedi, M.; Alsaeidi, S.; Sobhani, R.; Samani, R.E. Effect of melatonin in the prevention of postoperative pericardial adhesion formation. Interact. Cardiovasc. Thorac. Surg. 2009, 9, 26-28. [CrossRef] [PubMed]

213. Lopes, J.B.; Dallan, L.A.; Lisboa, L.A.; Gutierrez, P.S.; Stolf, N.A.; Campana-Filho, S.P.; Moreira, L.F.P.; Oliveira, S.A. Keratinocyte growth factor: A new mesothelial targeted therapy to reduce postoperative pericardial adhesions? Eur. J. Cardio-Thoracic Surg. 2009, 35, 313-318. [CrossRef] [PubMed] 
214. Hioki, M.; Iedokoro, Y.; Yamagishi, S.; Yamashita, Y.; Orii, K.; Hirano, S.; Hirata, T.; Masuda, S.; Kutukata, N.; Hisayoshi, T.; et al. Prevention of postoperative pericardial adhesions with a defibrinogenating agent. Int. Surg. 1998, 83, 11-14. [PubMed]

215. Yagmurlu, A.; Barlas, M.; Gursel, I.; Gokcora, I.; Yagmurlu, A.; Barlas, M.; Gursel, I.; Gokcora, I. Reduction of Surgery-Induced Peritoneal Adhesions by Continuous Release of Streptokinase from a Drug Delivery System. Eur. Surg. Res. 2003, 35, 46-49. [CrossRef] [PubMed]

216. Fedan, J.S. Anticoagulant, antiplatelet, and fibrinolytic (thrombolytic) drugs. Mod. Pharmacol. 2004, 3, $370-385$.

217. Huemer, H.P. Possible Immunosuppressive Effects of Drug Exposure and Environmental and Nutritional Effects on Infection and Vaccination. Mediat. Inflamm. 2015, 2015, 1-7. [CrossRef]

218. Paccani, S.R.; Boncristiano, M.; Ulivieri, C.; D’Elios, M.M.; Del Prete, G.; Baldari, C.T. Nonsteroidal Anti-inflammatory Drugs Suppress T-cell Activation by Inhibiting p38 MAPK Induction. J. Biol. Chem. 2002, 277, 1509-1513. [CrossRef]

219. Paul, M.; Mehr, A.P.; Kreutz, R. Physiology of Local Renin-Angiotensin Systems. Physiol. Rev. 2006, 86, 747-803. [CrossRef]

220. Schönberger, T.; Fandrey, J.; Prost-Fingerle, K. Ways into Understanding HIF Inhibition. Cancers 2021, 13, 159. [CrossRef]

221. Jasińska, M.; Owczarek, J.; Orszulak-Michalak, D. Statins: A new insight into their mechanisms of action and consequent pleiotropic effects. Pharmacol. Rep. 2007, 59, 483-499.

222. Huang, Y.; Furuno, M.; Arakawa, T.; Takizawa, S.; De Hoon, M.; Suzuki, H.; Arner, E. A framework for identification of on- and off-target transcriptional responses to drug treatment. Sci. Rep. 2019, 9, 1-9. [CrossRef]

223. Efimova, E.V.; Ricco, N.; Labay, E.; Mauceri, H.J.; Flor, A.C.; Ramamurthy, A.; Sutton, H.G.; Weichselbaum, R.R.; Kron, S.J. HMG-CoA Reductase Inhibition Delays DNA Repair and Promotes Senescence After Tumor Irradiation. Mol. Cancer Ther. 2018, 17, 407-418. [CrossRef] [PubMed]

224. Arooj, M.; Sakkiah, S.D.; Cao, G.P.; Kim, S.; Arulalapperumal, V.; Lee, K.W. Finding off-targets, biological pathways, and target diseases for chymase inhibitors via structure-based systems biology approach. Proteins 2015, 83, 1209-1224. [CrossRef] [PubMed]

225. Liu, Y.; Li, H.; Shu, X.Z.; Gray, S.D.; Prestwich, G.D. Crosslinked hyaluronan hydrogels containing mitomycin C reduce postoperative abdominal adhesions. Fertil. Steril. 2005, 83, 1275-1283. [CrossRef] [PubMed]

226. Mitchell, J.D.; Lee, R.; Hodakowski, G.T.; Neya, K.; Harringer, W. Prevention of postoperative pericardial adhesions with a hyaluronic acid coating solution: Experimental safety and efficacy studies. J. Thorac. Cardiovasc. Surg. 1993, 107, 1481-1488. [CrossRef]

227. Urman, B.; Gomel, V.; Jetha, N. Effect of hyaluronic acid on postoperative intraperitoneal adhesion formation in the rat model. Fertil. Steril. 1991, 56, 563-567. [CrossRef]

228. Hagberg, L.; Gerdin, B. Sodium hyaluronate as an adjunct in adhesion prevention after flexor tendon surgery in rabbits. J. Hand Surg. 1992, 17, 935-941. [CrossRef]

229. Mitchell, J.D.; Lee, R.; Neya, K.; Vlahakes, G.J. Reduction in experimental pericardial adhesions using a hyaluronic acid bioabsorbable membrane. Eur. J. Cardio Thorac. Surg. 1994, 8, 149-152. [CrossRef]

230. Himeda, Y.; Yanagi, S.; Kakema, T.; Fujita, F.; Umeda, T.; Miyoshi, T. Adhesion Preventive Effect of a Novel Hyaluronic Acid Gel Film in Rats. J. Int. Med. Res. 2003, 31, 509-516. [CrossRef] [PubMed]

231. Seeger, J.M.; Kaelin, L.D.; Staples, E.M.; Yaacobi, Y.; Bailey, J.C.; Normann, S.; Burns, J.W.; Goldberg, E.P. Prevention of Postoperative Pericardial Adhesions Using Tissue-Protective Solutions. J. Surg. Res. 1997, 68, 63-66. [CrossRef]

232. Kataria, H.; Singh, V.P. Liquid Paraffin vs Hyaluronic Acid in Preventing Intraperitoneal Adhesions. Indian J. Surg. 2016, 79, 539-543. [CrossRef] [PubMed]

233. Cho, W.J.; Oh, S.H.; Lee, J.H. Alginate Film as a Novel Post-Surgical Tissue Adhesion Barrier. J. Biomater. Sci. Polym. Ed. 2010, 21, 701-713. [CrossRef]

234. Sawada, T.; Tsukada, K.; Hasegawa, K.; Ohashi, Y.; Udagawa, Y.; Gomel, V. Cross-linked hyaluronate hydrogel prevents adhesion formation and reformation in mouse uterine horn model. Hum. Reprod. 2001, 16, 353-356. [CrossRef]

235. Can, S.; Kirpinar, G.; Dural, O.; Karamustafaoglu, B.B.; Tas, I.S.; Yasa, C.; Ugurlucan, F.G. Efficacy of a New Crosslinked Hyaluronan Gel in the Prevention of Intrauterine Adhesions. JSLS J. Soc. Laparoendosc. Surg. 2018, 22. [CrossRef] [PubMed]

236. Mais, V.; Cirronis, M.G.; Peiretti, M.; Ferrucci, G.; Cossu, E.; Melis, G.B. Efficacy of auto-crosslinked hyaluronan gel for adhesion prevention in laparoscopy and hysteroscopy: A systematic review and meta-analysis of randomized controlled trials. Eur. J. Obstet. Gynecol. Reprod. Biol. 2012, 160, 1-5. [CrossRef] [PubMed]

237. Gago, L.A.; Saed, G.M.; Wang, R.X.; Kruger, M.; Diamond, M.P. Effects of oxidized regenerated cellulose on the expression of extracellular matrix and transforming growth factor-beta1 in human peritoneal fibroblasts and mesothelial cells. Am. J. Obstet. Gynecol. 2003, 189, 1620-1625. [CrossRef] [PubMed]

238. Gago, L.; Saed, G.; Elhammady, E.; Diamond, M. Effect of oxidized regenerated cellulose (Interceed ${ }^{\circledR}$ ) on the expression of tissue plasminogen activator and plasminogen activator inhibitor-1 in human peritoneal fibroblasts and mesothelial cells. Fertil. Steril. 2006, 86, 1223-1227. [CrossRef]

239. Reddy, S.; Santanam, N.; Reddy, P.; Rock, J.A.; Murphy, A.A.; Parthasarathy, S. Interaction of Interceed oxidized regenerated cellulose with macrophages: A potential mechanism by which Interceed may prevent adhesions. Am. J. Obstet. Gynecol. 1997, 177, 1315-1321. [CrossRef]

240. Diamond, M.P.; Linsky, C.B.; Cunningham, T.; Kamp, L.; Pines, E.; DeCherney, A.H.; Dizerega, G.S. Synergistic effects of INTERCEED(TC7) and heparin in reducing adhesion formation in the rabbit uterine horn model. Fertil. Steril. 1991, 55, 389-394. [CrossRef] 
241. Diamond, M.P.; Linsky, C.B.; Cunningham, T.; Kamp, L.; Pines, E.; DeCherney, A.H.; Dizerega, G.S. Adhesion Reformation: Reduction by the Use of Interceed (TC7) Plus Heparin. J. Gynecol. Surg. 1991, 7, 1-6. [CrossRef] [PubMed]

242. Biçer, M.; Bayram, A.S.; Gürbüz, O.; Şenkaya, I.; Yerci, Ö.; Tok, M.; Anğ, E.; Moğol, E.B.; Saba, D. Assessment of the Efficacy of the Bio-Absorbable Oxidized Regenerated Cellulose for Prevention of Post-Operative Pericardial Adhesion in the Rabbit Model. J. Int. Med. Res. 2008, 36, 1311-1318. [CrossRef] [PubMed]

243. Menguellet, S.A.; Collinet, P.; Cosson, M.; Mariette, C.; Triboulet, J.P.; Vinatier, D. Interest in agents for adhesion prevention after gynecologic surgery. Gynecol. Obstet. Fertil. 2007, 35, 290-296.

244. Sekiba, K. Use of INTERCEED (TC7) absorbable adhesion barrier to reduce postoperative adhesion formation in infertility and endometriosis surgery. Prog. Clin. Boil. Res. 1993, 381, 221-233.

245. Franklin, R.R. Reduction of ovarian adhesions by the use of interceed. Obstet. Gynecol. 1995, 86, 335-340. [CrossRef]

246. Azziz, R. Microsurgery alone or with INTERCEED Absorbable Adhesion Barrier for pelvic sidewall adhesion re-formation. The INTERCEED (TC7) Adhesion Barrier Study Group II. Surg. Gynecol. Obstet. 1993, 177, 135-139. [PubMed]

247. Nordic Adhesion Prevention Study Group. The efficacy of Interceed (TC7)* for prevention of reformation of postoperative adhesions on ovaries, fallopian tubes, and fimbriae in microsurgical operations for fertility: A multicenter study. Fertil. Steril. 1995, 63, 709-714.

248. Mais, V.; Ajossa, S.; Piras, B.; Guerriero, S.; Marongiu, D.; Melis, G.B. Prevention of de-novo adhesion formation after laparoscopic myomectomy: A randomized trial to evaluate the effectiveness of an oxidized regenerated cellulose absorbable barrier. Hum. Reprod. 1995, 10, 3133-3135. [CrossRef]

249. Farquhar, C.M.; Vandekerckhove, P.; Watson, A.; Vail, A.; Wiseman, D. Barrier agents for preventing adhesions after surgery for subfertility. Cochrane Database Syst. Rev. 1999, 2000, CD000475. [CrossRef]

250. Baysal, B. Comparison of the resorbable barrier interceed (TC7) and preoperative use of medroxyprogesterone acetate in postoperative adhesion prevention. Clin. Exp. Obstet. Gynecol. 2001, 28, 126-127.

251. Best, C.L.; Rittenhouse, D.; Sueldo, C.; Best, C.L.; Rittenhouse, D.; Sueldo, C. A comparison of TC7 and $32 \%$ dextran 70 for prevention of postoperative adhesions in hamsters. Obstet. Gynecol. 1991, 78, 858-860.

252. Ortega-Moreno, J. Effects of TC7 associated to $32 \%$ dextran 70, heparin and carboxymethylcellulose in adhesion prevention in the rat. Arch. Gynecol. Obstet. 1993, 253, 27-32. [CrossRef]

253. Harris, E.S.; Morgan, R.F.; Rodeheaver, G.T. Analysis of the kinetics of peritoneal adhesion formation in the rat and evaluation of potential antiadhesive agents. Surgery 1995, 117, 663-669. [CrossRef]

254. Wiseman, D.M.; Trout, J.R.; Franklin, R.R.; Diamond, M.P. Meta-analysis of the safety and efficacy of an adhesion barrier (Interceed TC7) in laparotomy. J. Reprod. Med. 1999, 44, 325-331.

255. De Cherney, A.H.; di Zerega, G.S. Clinical problem of intraperitoneal postsurgical adhesion formation following general surgery and the use of adhesion prevention barriers. Surg. Clin. N. Am. 1997, 77, 671-688. [CrossRef]

256. Ward, B.; Panitch, A. Abdominal Adhesions: Current and Novel Therapies. J. Surg. Res. 2011, 165, 91-111. [CrossRef] [PubMed]

257. Haney, A.; Doty, E. Murine peritoneal injury and de novo adhesion formation caused by oxidized-regenerated cellulose (Interceed [TC7]) but not expanded polytetrafluoroethylene (Gore-Tex Surgical Membrane). Fertil. Steril. 1992, 57, 202-208. [CrossRef]

258. Diamond, M.P.; Burns, E.L.; Accomando, B.; Mian, S.; Holmdahl, L. Seprafilm ${ }^{\circledR}$ adhesion barrier: (1) a review of preclinical, animal, and human investigational studies. Gynecol. Surg. 2012, 9, 237-245. [CrossRef] [PubMed]

259. Buckenmaier, C.C.; Pusateri, A.E.; Harris, R.A.; Hetz, S.P. Comparison of antiadhesive treatments using an objective rat model. Am. Surg. 1999, 65, 274-282. [PubMed]

260. Szabo, A.; Haj, M.; Waxsman, I.; Eitan, A. Evaluation of seprafilm and amniotic membrane as adhesion prophylaxis in mesh repair of abdominal wall hernia in rats. Eur. Surg. Res. 2000, 32, 125-128. [CrossRef]

261. Altuntas, I.; Tarhan, O.; Delibas, N. Seprafilm reduces adhesions to polypropylene mesh and increases peritoneal hydroxyproline. Am. Surg. 2002, 68, 759-761. [PubMed]

262. Burns, J.W.; Colt, M.J.; Burgees, L.S.; Skinner, K.C. Preclinical evaluation of Seprafilm bioresorbable membrane. Eur. J. Surg. Suppl. Acta Chir. Suppl. 1997, 1997, 40-48.

263. Alponat, A.; Lakshminarasappa, S.R.; Yavuz, N.; Goh, P.M. Prevention of adhesions by Seprafilm, an absorbable adhesion barrier: An incisional hernia model in rats. Am. Surg. 1997, 63, 818-819.

264. Numanoğlu, V.; Cihan, A.; Salman, B.; Ucan, B.H.; Cakmak, G.K.; Cesur, A.; Balbaloglu, H.; Ilhan, M.N. Comparison Between Powdered Gloves, Powder-free Gloves and Hyaluronate/Carboxymethylcellulose Membrane on Adhesion Formation in a Rat Caecal Serosal Abrasion Model. Asian J. Surg. 2007, 30, 96-101. [CrossRef]

265. Lee, M.-W.; Hung, C.-L.; Cheng, J.-C.; Wang, Y.-J. A new anti-adhesion film synthesized from polygalacturonic acid with 1-ethyl-3-(3-dimethylaminopropyl)carbodiimide crosslinker. Biomaterials 2005, 26, 3793-3799. [CrossRef] [PubMed]

266. El-Ghoul, W. The effects of combined liquid and membrane barriers in prevention of post-operative intra-abdominal adhesions after experimental jejunal anastomosis in dogs. Dtsch. Tierarztl. Wochenschr. 2005, 112, 3-10.

267. Van 't Riet, M.; de vos van Steenwijk, P.J.; Bonthuis, F.; Marquet, R.L.; Steyerberg, E.W.; Jeekel, J.; Bonjer, H.J. Prevention of adhesion to prosthetic mesh: Comparison of different barriers using an incisional hernia model. Ann. Surg. 2003, 237, 123-128. [CrossRef]

268. Bülbüller, N.; Sapmaz, E.; Akpolat, N.; Ustundag, B.; Kirkil, C. Effect of a bioresorbable membrane on postoperative adhesions and wound healing. J. Reprod. Med. 2003, 48, 547-550. 
269. Eroglu, A.; Demirci, S.; Kurtman, C.; Akbay, A.; Eroglu, N. Prevention of intra-abdominal adhesions by using Seprafilm in rats undergoing bowel resection and radiation therapy. Colorectal Dis. 2001, 3, 33-37. [CrossRef]

270. Ersoy, E.; Ozturk, V.; Yazgan, A.; Ozdogan, M.; Gundogdu, H. Comparison of the Two Types of Bioresorbable Barriers to Prevent Intra-Abdominal Adhesions in Rats. J. Gastrointest. Surg. 2008, 13, 282-286. [CrossRef]

271. Osada, H.; Minai, M.; Tsunoda, I.; Fujii, T.; Tsubata, K.; Satoh, K. The Effect of Hyaluronic Acid-Carboxymethylcellulose in Reducing Adhesion Reformation in Rabbits. J. Int. Med. Res. 1999, 27, 292-296. [CrossRef]

272. Naito, Y.; Shin'Oka, T.; Hibino, N.; Matsumura, G.; Kurosawa, H. A novel method to reduce pericardial adhesion: A combination technique with hyaluronic acid biocompatible membrane. J. Thorac. Cardiovasc. Surg. 2008, 135, 850-856. [CrossRef] [PubMed]

273. Ballore, L.; Orrù, F.; Nicolini, F.; Contini, S.; Galletti, G.; Gherli, T. Experimental results of the use of hyaluronic acid based materials (CV Seprafilm and CV Sepracoat) in postoperative pericardial adhesions. Acta Bio Med. L'Ateneo Parm. 2000, 71, 159-166.

274. Mueller, X.; Tevaearai, H.; Augstburger, M.; Burki, M.; Von Segesser, L.K. Prevention of Pericardial Adhesions with a Bioresorbable Membrane. Swiss Surg. 1999, 5, 23-26. [CrossRef]

275. Altuntas, Y.E.; Kement, M.; Oncel, M.; Sahip, Y.; Kaptanoglu, L. The Effectiveness of Hyaluronan-Carboxymethylcellulose Membrane in Different Severity of Adhesions Observed at the Time of Relaparotomies: An Experimental Study on Mice. Dis. Colon Rectum 2008, 51, 1562-1565. [CrossRef] [PubMed]

276. Tsuji, S.; Takahashi, K.; Yomo, H.; Fujiwara, M.; Kita, N.; Takebayashi, K.; Miyazaki, K.; Noda, Y. Effectiveness of antiadhesion barriers in preventing adhesion after myomectomy in patients with uterine leiomyoma. Eur. J. Obstet. Gynecol. Reprod. Biol. 2005, 123, 244-248. [CrossRef] [PubMed]

277. Salum, M.; Wexner, S.D.; Nogueras, J.J.; Weiss, E.; Koruda, M.; Behrens, K.; Cohen, S.; Binderow, S.; Cohen, J.; Thorson, A.; et al. Does sodium hyaluronate- and carboxymethylcellulose-based bioresorbable membrane (Seprafilm) decrease operative time for loop ileostomy closure? Tech. Coloproctol. 2006, 10, 187-191. [CrossRef]

278. Kusunoki, M.; Ikeuchi, H.; Yanagi, H.; Noda, M.; Tonouchi, H.; Mohri, Y.; Uchida, K.; Inoue, Y.; Kobayashi, M.; Miki, C.; et al. Bioresorbable Hyaluronate-Carboxymethylcellulose Membrane (Seprafilm) in Surgery for Rectal Carcinoma: A Prospective Randomized Clinical Trial. Surg. Today 2005, 35, 940-945. [CrossRef]

279. Khaitan, L.; Scholz, S.; Houston, H.; Richards, W. Results after laparoscopic lysis of adhesions and placement of seprafilm for intractable abdominal pain. Surg. Endosc. 2003, 17, 247-253. [CrossRef]

280. Tsapanos, V.S.; Stathopoulou, L.P.; Papathanassopoulou, V.S.; Tzingounis, V.A. The role of Seprafilm? bioresorbable membrane in the prevention and therapy of endometrial synechiae. J. Biomed. Mater. Res. 2002, 63, 10-14. [CrossRef]

281. Diamond, M. Reduction of adhesions after uterine myomectomy by Seprafilm membrane (HAL-F): A blinded, prospective, randomized, multicenter clinical study. Seprafilm Adhesion Study Group. Fertil. Steril. 1996, 66, 904-910. [CrossRef]

282. Duffy, J.M.N.; Farquhar, C.; Vail, A.; Vandekerckhove, P.; Watson, A.; Wiseman, D.; Vanderkerchove, P. Barrier agents for adhesion prevention after gynaecological surgery. Cochrane Database Syst. Rev. 2008, 2008, CD000475. [CrossRef]

283. Inoue, M.; Uchida, K.; Miki, C.; Kusunoki, M. Efficacy of Seprafilm for reducing reoperative risk in pediatric surgical patients undergoing abdominal surgery. J. Pediatr. Surg. 2005, 40, 1301-1306. [CrossRef] [PubMed]

284. Bristow, R.E.; Montz, F. Prevention of adhesion formation after radical oophorectomy using a sodium hyaluronatecarboxymethylcellulose (HA-CMC) barrier. Gynecol. Oncol. 2005, 99, 301-308. [CrossRef] [PubMed]

285. Mohri, Y.; Uchida, K.; Araki, T.; Inoue, Y.; Tonouchi, H.; Miki, C.; Kusunoki, M. Hyaluronic Acid-Carboxycellulose Membrane (Seprafilm) Reduces Early Postoperative Small Bowel Obstruction in Gastrointestinal Surgery. Am. Surg. 2005, 71, 861-863. [CrossRef] [PubMed]

286. Vrijland, W.W.; Tseng, L.N.; Eijkman, H.J.; Hop, W.C.; Jakimowicz, J.J.; Leguit, P.; Stassen, L.P.; Swank, D.J.; Haverlag, R.; Bonjer, H.J.; et al. Fewer intraperitoneal adhesions with use of hyaluronic acid-carboxymethylcellulose membrane: A randomized clinical trial. Ann. Surg. 2002, 235, 193-199. [CrossRef] [PubMed]

287. Lefort, B.; El Arid, J.-M.; Bouquiaux, A.-L.; Soulé, N.; Chantreuil, J.; Tavernier, E.; Chantepie, A.; Neville, P. Is Seprafilm valuable in infant cardiac redo procedures? J. Cardiothorac. Surg. 2015, 10, 47. [CrossRef] [PubMed]

288. Zeng, Q.; Yu, Z.; You, J.; Zhang, Q. Efficacy and Safety of Seprafilm for Preventing Postoperative Abdominal Adhesion: Systematic Review and Meta-analysis. World J. Surg. 2007, 31, 2125-2131. [CrossRef]

289. Takeuchi, H.; Kitade, M.; Kikuchi, I.; Shimanuki, H.; Kinoshita, K. A Novel Instrument and Technique for Using Seprafilm Hyaluronic Acid/Carboxymethylcellulose Membrane During Laparoscopic Myomectomy. J. Laparoendosc. Adv. Surg. Tech. 2006, 16, 497-502. [CrossRef]

290. Johns, A. Evidence-based prevention of post-operative adhesions. Hum. Reprod. Update 2001, 7, 577-579. [CrossRef]

291. Kumar, S.; Wong, P.F.; Leaper, D.J. Intra-peritoneal prophylactic agents for preventing adhesions and adhesive intestinal obstruction after non-gynaecological abdominal surgery. Cochrane Database Syst. Rev. 2009, 2009, CD005080. [CrossRef]

292. Zhou, J.; Lee, J.M.; Jiang, P.; Henderson, S.; Lee, T.D. Reduction in postsurgical adhesion formation after cardiac surgery by application of N,O-carboxymethyl chitosan. J. Thorac. Cardiovasc. Surg. 2010, 140, 801-806. [CrossRef]

293. Krause, T.J.; Zazanis, G.; Malatesta, P.; Solina, A. Prevention of Pericardial Adhesions with N-O Carboxymethylchitosan in the Rabbit Model. J. Investig. Surg. 2001, 14, 93-97. [CrossRef]

294. Tian, L.; Li, H.; Li, Y.; Liu, K.; Sun, Y.; Cong, Z.; Luan, X.; Li, Y.; Chen, J.; Wang, L.; et al. A Combination of Chitosan, Cellulose, and Seaweed Polysaccharide Inhibits Postoperative Intra-abdominal Adhesion in Rats. J. Pharmacol. Exp. Ther. 2017, 364, 399-408. [CrossRef] [PubMed] 
295. Chen, C.-H.; Chen, S.-H.; Mao, S.-H.; Tsai, M.-J.; Chou, P.-Y.; Liao, C.-H.; Chen, J.-P. Injectable thermosensitive hydrogel containing hyaluronic acid and chitosan as a barrier for prevention of postoperative peritoneal adhesion. Carbohydr. Polym. 2017, 173, 721-731. [CrossRef]

296. Wei, C.-Z.; Hou, C.-L.; Gu, Q.-S.; Jiang, L.-X.; Zhu, B.; Sheng, A.-L. A thermosensitive chitosan-based hydrogel barrier for post-operative adhesions' prevention. Biomaterials 2009, 30, 5534-5540. [CrossRef]

297. Lauder, C.I.; Garcea, G.; Strickland, A.; Maddern, G.J. Use of a Modified Chitosan-Dextran Gel to Prevent Peritoneal Adhesions in a Rat Model. J. Surg. Res. 2011, 171, 877-882. [CrossRef] [PubMed]

298. Daroz, L.R.; Lopes, J.B.; Dallan, L.A.; Campana-Filho, S.P.; Moreira, L.F.; Stolf, N.A. Prevention of postoperative pericardial adhesions using thermal sterile carboxymethyl chitosan. Rev. Bras. Cir. Cardiovasc. 2008, 23, 480-487. [CrossRef]

299. Zhou, J.; Liwski, R.S.; Elson, C.; Lee, T.D. Reduction in postsurgical adhesion formation after cardiac surgery in a rabbit model using N,O-carboxymethyl chitosan to block cell adherence. J. Thorac. Cardiovasc. Surg. 2008, 135, 777-783. [CrossRef] [PubMed]

300. Hu, Z.; Zhang, D.-Y.; Lu, S.-T.; Li, P.-W.; Li, S.-D. Chitosan-Based Composite Materials for Prospective Hemostatic Applications. Mar. Drugs 2018, 16, 273. [CrossRef] [PubMed]

301. Kennedy, R.; Costain, D.J.; McAlister, V.C.; Lee, T.D. Prevention of experimental postoperative peritoneal adhesions by N,Ocarboxymethyl chitosan. Surgery 1996, 120, 866-870. [CrossRef]

302. Zhou, J.; Elson, C.; Lee, T.D.G. Reduction in postoperative adhesion formation and re-formation after an abdominal operation with the use of N,O-carboxymethyl chitosan. Surgery 2004, 135, 307-312. [CrossRef] [PubMed]

303. Diamond, M.P.; Luciano, A.; Johns, D.A.; Dunn, R.; Young, P.; Bieber, E. Reduction of postoperative adhesions by N,Ocarboxymethylchitosan: A pilot study. Fertil. Steril. 2003, 80, 631-636. [CrossRef]

304. Falabella, C.A.; Melendez, M.M.; Weng, L.; Chen, W. Novel Macromolecular Crosslinking Hydrogel to Reduce Intra-Abdominal Adhesions. J. Surg. Res. 2010, 159, 772-778. [CrossRef]

305. Zhu, L.; Zhang, Y.-Q. Postoperative anti-adhesion ability of a novel carboxymethyl chitosan from silkworm pupa in a rat cecal abrasion model. Mater. Sci. Eng. C 2016, 61, 387-395. [CrossRef]

306. Cai, X.; Hu, S.; Yu, B.; Cai, Y.; Yang, J.; Li, F.; Zheng, Y.; Shi, X. Transglutaminase-catalyzed preparation of crosslinked carboxymethyl chitosan/carboxymethyl cellulose/collagen composite membrane for postsurgical peritoneal adhesion prevention. Carbohydr. Polym. 2018, 201, 201-210. [CrossRef]

307. Cheng, F.; Wu, Y.; Li, H.; Yan, T.; Wei, X.; Wu, G.; He, J.; Huang, Y. Biodegradable N, O-carboxymethyl chitosan/oxidized regenerated cellulose composite gauze as a barrier for preventing postoperative adhesion. Carbohydr. Polym. 2019, 207, 180-190. [CrossRef]

308. Okuyama, N.; Rodgers, K.E.; Wang, C.Y.; Girgis, W.; Oz, M.; Amand, K.S.; Pines, E.; DeCherney, A.H.; Rose, E.A.; Cohn, D.; et al. Prevention of Retrosternal Adhesion Formation in a Rabbit Model Using Bioresorbable Films of Polyethylene Glycol and Polylactic Acid. J. Surg. Res. 1998, 78, 118-122. [CrossRef]

309. Schreiber, C.; Boening, A.; Kostolny, M.; Pines, E.; Cremer, J.; Lange, R.; Scheewe, J. European clinical experience with REPEL-CV ${ }^{\circledR}$. Expert Rev. Med. Devices 2007, 4, 291-295. [CrossRef]

310. Lodge, A.J.; Wells, W.J.; Backer, C.L.; O’Brien, J.E.; Austin, E.H.; Bacha, E.A.; Yeh, T.; De Campli, W.M.; Lavin, P.T.; Weinstein, S. A Novel Bioresorbable Film Reduces Postoperative Adhesions After Infant Cardiac Surgery. Ann. Thorac. Surg. 2008, 86, 614-621. [CrossRef] [PubMed]

311. Allègre, L.; Le Teuff, I.; Leprince, S.; Warembourg, S.; Taillades, H.; Garric, X.; Letouzey, V.; Huberlant, S. A new bioabsorbable polymer film to prevent peritoneal adhesions validated in a post-surgical animal model. PLoS ONE 2018, 13, e0202285. [CrossRef]

312. Rastan, A.; Mohr, F.W.; Haensig, M. Bioresorbable adhesion barrier for reducing the severity of postoperative cardiac adhesions: Focus on REPEL-CV ${ }^{\circledR}$. Med. Devices Évid. Res. 2011, 4, 17-25. [CrossRef]

313. Rodgers, K.; Cohn, D.; Hotovely, A.; Pines, E.; Diamond, M.P.; di Zerega, G. Evaluation of polyethylene glycol/polylactic acid films in the prevention of adhesions in the rabbit adhesion formation and reformation sidewall models. Fertil. Steril. 1998, 69, 403-408. [CrossRef]

314. Chen, Z.; Zheng, J.; Zhang, J.; Li, S. A novel bioabsorbable pericardial membrane substitute to reduce postoperative pericardial adhesions in a rabbit model. Interact. Cardiovasc. Thorac. Surg. 2015, 21, 565-572. [CrossRef]

315. Yoshioka, I.; Saiki, Y.; Sakuma, K.; Iguchi, A.; Moriya, T.; Ikada, Y.; Tabayashi, K. Bioabsorbable Gelatin Sheets Latticed with Polyglycolic Acid Can Eliminate Pericardial Adhesion. Ann. Thorac. Surg. 2007, 84, 864-870. [CrossRef] [PubMed]

316. Avital, S.; Bollinger, T.J.; Wilkinson, J.; Marchetti, F.; Hellinger, M.D.; Sands, L.R. Preventing Intra-Abdominal Adhesions with Polylactic Acid Film: An Animal Study. Dis. Colon Rectum 2005, 48, 153-157. [CrossRef]

317. Schug-Paß, C.; Sommerer, F.; Tannapfel, A.; Lippert, H.; Köckerling, F. Does the additional application of a polylactide film (SurgiWrap) to a lightweight mesh (TiMesh) reduce adhesions after laparoscopic intraperitoneal implantation procedures? Experimental results obtained with the laparoscopic porcine model. Surg. Endosc. 2008, 22, 2433-2439. [CrossRef]

318. Hsu, C.W.; Chang, M.C.; Wang, J.H.; Wu, C.C.; Chen, Y.H. Placement of SurgiWrap ${ }^{\circledR}$ adhesion barrier film around the protective loop stoma after laparoscopic colorectal cancer surgery may reduce the peristomal adhesion severity and facilitate the closure. Int. J. Colorectal Dis. 2019, 34, 513-518. [CrossRef] [PubMed]

319. Al-Jaroudi, D.; Tulandi, T. Adhesion Prevention in Gynecologic Surgery. Obstet. Gynecol. Surv. 2004, 59, 360-367. [CrossRef] [PubMed] 
320. Minale, C.; Nikol, S.; Hollweg, G.; Mittermayer, C.; Messmer, B.J. Clinical Experience with Expanded Polytetrafluoroethylene Gore-Tex ${ }^{\circledR}$ Surgical Membrane for Pericardial Closure: A Study of 110 Cases. J. Card. Surg. 1988, 3, 193-201. [CrossRef]

321. González-Quintero, V.H.; Cruz-Pachano, F.E. Preventing Adhesions in Obstetric and Gynecologic Surgical Procedures. Rev. Obstet. Gynecol. 2009, 2, 38-45.

322. Di Zerega, G.S. Contemporary adhesion prevention. Fertil. Steril. 1994, 61, 219-235. [CrossRef]

323. Magro, B.; Mita, P.; Bracco, G.L.; Coccia, E.; Scarselli, G. Expanded polytetrafluoroethylene surgical membrane in ovarian surgery on the rabbit. Biocompatibility, adhesion prevention properties and ability to preserve reproductive capacity. J. Reprod. Med. 1996, $41,73-78$.

324. Kaan, G.L.; Smedts, F.; Van Son, J.A.; Vincent, J.G.; Kubat, K.; Skotnicki, S.H.; Lacquet, L.K. Prevention of adhesion formation around the internal mammary artery pedicle by Gore-Tex surgical membrane. An experimental study in goats. Eur. J. CardioThoracic Surg. 1993, 7, 81-83. [CrossRef]

325. Hellebrekers, B.; Trimbos-Kemper, G.; Van Blitterswijk, C.; Bakkum, E.; Trimbos, J. Effects of five different barrier materials on postsurgical adhesion formation in the rat. Hum. Reprod. 2000, 15, 1358-1363. [CrossRef]

326. The Myomectomy Adhesion Multicenter Study Group. An expanded polytetrafluoroethylene barrier (Gore-Tex Surgical Membrane) reduces post-myomectomy adhesion formation. Fertil. Steril. 1995, 63, 491-493. [CrossRef]

327. Haney, A.F.; Doty, E. Expanded-polytetrafluoroethylene but not oxidized regenerated cellulose prevents adhesion formation and reformation in a mouse uterine horn model of surgical injury. Fertil. Steril. 1993, 60, 550-558. [CrossRef]

328. Grow, D.R.; Seltman, H.J.; Coddington, C.C.; Hodgen, G.D. The reduction of postoperative adhesions by two different barrier methods versus control in cynomolgus monkeys: A prospective, randomized, crossover study. Fertil. Steril. 1994, 61, 1141-1146. [CrossRef]

329. Anderson, J.M.; Rodriguez, A.; Chang, D.T. Foreign body reaction to biomaterials. Semin. Immunol. 2008, 20, 86-100. [CrossRef] [PubMed]

330. Jacobs, J.P.; Iyer, R.S.; Weston, J.S.; Amato, J.J.; Elliott, M.J.; De Leval, M.R.; Stark, J. Expanded PTFE Membrane to Prevent Cardiac Injury During Resternotomy for Congenital Heart Disease. Ann. Thorac. Surg. 1996, 62, 1778-1782. [CrossRef]

331. Tsukihara, H.; Takamoto, S.; Kitahori, K.; Matsuda, K.; Murakami, A.; Novick, R.J.; Suematsu, Y. Prevention of postoperative pericardial adhesions with a novel regenerative collagen sheet. Ann. Thorac. Surg. 2006, 81, 650-657. [CrossRef]

332. Hurst, B.S. Permanent implantation of expanded polytetrafluoroethylene is safe for pelvic surgery. Hum. Reprod. 1999, 14, 925-927. [CrossRef]

333. Kuschel, T.J.; Gruszka, A.; Hermanns-Sachweh, B.; Elyakoubi, J.; Sachweh, J.S.; Vázquez-Jiménez, J.F.; Schnoering, H. Prevention of Postoperative Pericardial Adhesions with TachoSil. Ann. Thorac. Surg. 2013, 95, 183-188. [CrossRef]

334. Quinino, R.M.; Araujo-Filho, I.; Lima, F.P.; Barbosa, A.L.; Tde, C.M.; Goldenberg, A. Adhesion prevention in reabsorbable polyethylene glycol hydrogel (Coseal(R)) coated polypropylene mesh in rabbits. Acta Cir. Bras. 2013, 28, 807-814. [CrossRef]

335. Fukuhira, Y.; Ito, M.; Kaneko, H.; Sumi, Y.; Tanaka, M.; Yamamoto, S.; Shimomura, M. Prevention of postoperative adhesions by a novel honeycomb-patterned poly(lactide) film in a rat experimental model. J. Biomed. Mater. Res. Part B Appl. Biomater. 2008, 86, 353-359. [CrossRef]

336. Cho, W.J.; Oh, S.H.; Kim, I.G.; Lee, C.S.; Lee, J.H. Prevention of postsurgical tissue adhesion by a bi-layer membrane consisting of adhesion and lubrication layers. Tissue Eng. Regen. Med. 2010, 7, 49-56.

337. Yamaoka, T.; Takahashi, Y.; Fujisato, T.; Lee, C.W.; Tsuji, T.; Ohta, T.; Murakami, A.; Kimura, Y. Novel adhesion prevention membrane based on a bioresorbable copoly(ester-ether) comprised of poly-L-lactide and Pluronic: In vitro and in vivo evaluations. J. Biomed. Mater. Res. 2001, 54, 470-479. [CrossRef]

338. Abraham, L.C.; Zuena, E.; Perez-Ramirez, B.; Kaplan, D.L. Guide to collagen characterization for biomaterial studies. J. Biomed. Mater. Res. Part B Appl. Biomater. 2008, 87, 264-285. [CrossRef]

339. Schreinemacher, M.H.F.; Emans, P.J.; Gijbels, M.J.J.; Greve, J.M.; Beets, G.L.; Bouvy, N.D. Degradation of mesh coatings and intraperitoneal adhesion formation in an experimental model. BJS 2009, 96, 305-313. [CrossRef] [PubMed]

340. Riet, M.V.; Burger, J.W.; Bonthuis, F.; Jeekel, J.; Bonjer, H.J. Prevention of adhesion formation to polypropylene mesh by collagen coating: A randomized controlled study in a rat model of ventral hernia repair. Surg. Endosc. 2004, 18, 681-685.

341. Rodríguez, M.; Pascual, G.; Sotomayor, S.; Köhler, B.P.; Cifuentes, A.; Bellón, J.M. Chemical Adhesion Barriers: Do They Affect the Intraperitoneal Behavior of a Composite Mesh? J. Investig. Surg. 2011, 24, 115-122. [CrossRef]

342. Schönleben, F.; Reck, T.; Tannapfel, A.; Hohenberger, W.; Schneider, I. Collagen foil (TissuFoil E) reduces the formation of adhesions when using polypropylene mesh for the repair of experimental abdominal wall defects. Int. J. Color. Dis. 2006, 21, 840-846. [CrossRef]

343. Brochhausen, C.; Schmitt, V.H.; Planck, C.N.E.; Rajab, T.K.; Hollemann, D.; Tapprich, C.; Krämer, B.; Wallwiener, C.W.; Hierlemann, H.; Zehbe, R.; et al. Current Strategies and Future Perspectives for Intraperitoneal Adhesion Prevention. J. Gastrointest. Surg. 2012, 16, 1256-1274. [CrossRef]

344. Edwards, G.A.; Glattauer, V.; Nash, T.J.; White, J.F.; Brock, K.A.; Werkmeister, J.A.; Ramshaw, J.A. In vivo evaluation of a collagenous membrane as an absorbable adhesion barrier. J. Biomed. Mater. Res. 1997, 34, 291-297. [CrossRef]

345. Butler, C.E.; Prieto, V.G. Reduction of Adhesions with Composite AlloDerm/Polypropylene Mesh Implants for Abdominal Wall Reconstruction. Plast. Reconstr. Surg. 2004, 114, 464-473. [CrossRef] [PubMed] 
346. Gonzalez, R.; Rodeheaver, G.T.; Moody, D.L.; Foresman, P.A.; Ramshaw, B.J. Resistance to adhesion formation: A comparative study of treated and untreated mesh products placed in the abdominal cavity. Hernia 2004, 8, 213-219. [CrossRef] [PubMed]

347. De Araújo, U.R.; Czeczko, N.G.; Ribas-Filho, J.M.; Malafaia, O.; Budel, V.M.; Balderrama, C.M.; Zimmermann, E.; Dietz, U.A. Intraperitoneal meshes in the repair of abdominal wall defects: Comparison of polyester with collagen versus polypropylene with polyglycolic acid. Rev. Col. Bras. Cir. 2009, 36, 241-249. [PubMed]

348. Judge, T.W.; Parker, D.M.; Dinsmore, R.C. Abdominal Wall Hernia Repair: A Comparison of Sepramesh and Parietex Composite Mesh in a Rabbit Hernia Model. J. Am. Coll. Surg. 2007, 204, 276-281. [CrossRef] [PubMed]

349. Hsu, P.W.; Salgado, C.J.; Kent, K.; Finnegan, M.; Pello, M.; Simons, R.; Atabek, U.; Kann, B. Evaluation of porcine dermal collagen (Permacol) used in abdominal wall reconstruction. J. Plast. Reconstr. Aesthetic Surg. 2009, 62, 1484-1489. [CrossRef]

350. Loganathan, A.; Ainslie, W.; Wedgwood, K. Initial evaluation of Permacol bioprosthesis for the repair of complex incisional and parastomal hernias. Surgery 2010, 8, 202-205. [CrossRef] [PubMed]

351. Ayubi, F.S.; Armstrong, P.J.; Mattia, M.S.; Parker, D.M. Abdominal wall hernia repair: A comparison of Permacol ${ }^{\circledR}$ and Surgisis ${ }^{\circledR}$ grafts in a rat hernia model. Hernia 2008, 12, 373-378. [CrossRef]

352. Bellón, J.M.; Rodríguez, M.; Honduvilla, N.G.; Pascual, G.; Gil, V.G.; Bujan, J. Peritoneal Effects of Prosthetic Meshes Used to Repair Abdominal Wall Defects: Monitoring Adhesions by Sequential Laparoscopy. J. Laparoendosc. Adv. Surg. Tech. 2007, 17, 160-166. [CrossRef]

353. Bellón, J.M.; Rodríguez, M.; Gómez-Gil, V.; Sotomayor, S.; Bujan, J.; Pascual, G. Postimplant intraperitoneal behavior of collagen-based meshes followed by laparoscopy. Surg. Endosc. 2011, 26, 27-35. [CrossRef] [PubMed]

354. Ansaloni, L.; Catena, F.; Coccolini, F.; Fini, M.; Gazzotti, F.; Giardino, R.; Pinna, A.D. Peritoneal Adhesions to Prosthetic Materials: An Experimental Comparative Study of Treated and Untreated Polypropylene Meshes Placed in the Abdominal Cavity. J. Laparoendosc. Adv. Surg. Tech. 2009, 19, 369-374. [CrossRef] [PubMed]

355. Wiseman, D.M.; Gravagna, P.; Bayon, Y.; Tayot, J.-L. Collagen membrane/fleece composite film reduces adhesions in the presence of bleeding in a rabbit uterine horn model. Fertil. Steril. 2001, 76, 175-180. [CrossRef]

356. Bel, A.; Kachatryan, L.; Bruneval, P.; Peyrard, S.; Gagnieu, C.; Fabiani, J.-N.; Menasché, P. A new absorbable collagen membrane to reduce adhesions in cardiac surgery. Interact. Cardiovasc. Thorac. Surg. 2010, 10, 213-216. [CrossRef]

357. Taksaudom, N.; Ketwong, M.; Lertprasertsuke, N.; Kongkaew, A. Postoperative Pericardial Adhesion Prevention Using Collagen Membrane in Pigs: A Pilot Study. Open J. Cardiovasc. Surg. 2017, 9. [CrossRef]

358. Armoiry, X.; Viprey, M.; Constant, H.; Aulagner, G.; Roux, A.S.; Huot, L.; Roubertie, F.; Ninet, J.; Henaine, R. Potential interest of a new absorbable collagen membrane in the prevention of adhesions in paediatric cardiac surgery: A feasibility study. Arch. Cardiovasc. Dis. 2013, 106, 433-439. [CrossRef]

359. Bel, A.; Ricci, M.; Piquet, J.; Bruneval, P.; Perier, M.-C.; Gagnieu, C.; Fabiani, J.-N.; Menasché, P. Prevention of postcardiopulmonary bypass pericardial adhesions by a new resorbable collagen membrane. Interact. Cardiovasc. Thorac. Surg. 2012, 14, 469-473. [CrossRef] [PubMed]

360. Dabrowski, A.; Lepère, M.; Zaranis, C.; Coelio, C.; Hauters, P. Efficacy and safety of a resorbable collagen membrane COVA+ ${ }^{\mathrm{TM}}$ for the prevention of postoperative adhesions in abdominal surgery. Surg. Endosc. 2015, 30, 2358-2366. [CrossRef] [PubMed]

361. Tsai, S.-W.; Fang, J.-F.; Yang, C.-L.; Chen, J.-H.; Su, L.-T.; Jan, S.-H. Preparation and Evaluation of a Hyaluronate-Collagen Film for Preventing Post-Surgical Adhesion. J. Int. Med. Res. 2005, 33, 68-76. [CrossRef]

362. Zardo, P.; Zhang, R.; Freermann, S.; Fischer, S. Properties of novel composite meshes in chest wall reconstruction: A comparative animal study. Ann. Thorac. Med. 2014, 9, 158-161. [CrossRef]

363. Arung, W.; Drion, P.; Detry, O. Sepramesh and postoperative peritoneal adhesions in a rat model. Acta Chir. Belg. 2016, 116, 357-361. [CrossRef]

364. Gruber-Blum, S.; Petter-Puchner, A.H.; Brand, J.; Fortelny, R.H.; Walder, N.; Oehlinger, W.; Koenig, F.; Redl, H. Comparison of three separate antiadhesive barriers for intraperitoneal onlay mesh hernia repair in an experimental model. BJS 2011, 98, 442-449. [CrossRef]

365. Karacam, V.; Onen, A.; Sanli, A.; Gurel, D.; Kargi, A.; Karapolat, S.; Ozdemir, N. Prevention of Pleural Adhesions Using a Membrane Containing Polyethylene Glycol in Rats. Int. J. Med. Sci. 2011, 8, 380-386. [CrossRef]

366. Canis, M.J.; Triopon, G.; Daraï, E.; Madelenat, P.; LeVêque, J.; Panel, P.; Fernandez, H.; Audebert, A.; Descamps, P.; Castaing, N.; et al. Adhesion prevention after myomectomy by laparotomy: A prospective multicenter comparative randomized single-blind study with second-look laparoscopy to assess the effectiveness of PREVADH ${ }^{\mathrm{TM}}$. Eur. J. Obstet. Gynecol. Reprod. Biol. 2014, 178, 42-47. [CrossRef] [PubMed]

367. Mabrut, J.-Y.; Favre, J.-P.; Desrousseaux, B.; Chipponi, J.; Arnaud, J.-P.; Domergue, J.; Duffas, J.P.; Fourtanier, G.; Flament, J.-B.; Gouillat, C.; et al. Safety and long-term outcome of a new concept for surgical adhesion-reduction strategies (Prevadh): A prospective, multicenter study. Hepatogastroenterology 2008, 55, 517-521. [PubMed]

368. Grainger, D.A.; Meyer, W.R.; DeCherney, A.H.; Diamond, M.P. The Use of Hyaluronic Acid Polymers to Reduce Postoperative Adhesions. J. Gynecol. Surg. 1991, 7, 97-101. [CrossRef]

369. Attard, J.-A.P.; MacLean, A.R. Adhesive small bowel obstruction: Epidemiology, biology and prevention. Can. J. Surg. 2007, 50, 291-300. [PubMed]

370. Rajab, T.K.; Wallwiener, C.W.; Brochhausen, C.; Hierlemann, H.; Kraemer, B.; Wallwiener, M. Adhesion prophylaxis using a copolymer with rationally designed material properties. Surgery 2009, 145, 196-201. [CrossRef] 
371. Stapleton, L.M.; Steele, A.N.; Wang, H.; Lopez Hernandez, H.; Yu, A.C.; Paulsen, M.J.; Smith, A.A.A.; Roth, G.A.; Thakore, A.D.; Lucian, H.J.; et al. Use of a supramolecular polymeric hydrogel as an effective post-operative pericardial adhesion barrier. Nat. Biomed. Eng. 2019, 3, 611-620. [CrossRef] [PubMed]

372. Konertz, W.F.; Kostelka, M.; Mohr, F.W.; Hetzer, R.; Hübler, M.; Ritter, J.; Liu, J.; Koch, C.; Block, J. Reducing the incidence and severity of pericardial adhesions with a sprayable polymeric matrix. Ann. Thorac. Surg. 2003, 76, 1270-1274. [CrossRef]

373. Hendrikx, M.M.; Mees, U.; Hill, A.C.; Egbert, B.; Coker, G.T.; Estridge, T.D. Evaluation of a novel synthetic sealant for inhibition of cardiac adhesions and clinical experience in cardiac surgery procedures. Heart Surg. Forum 2001, 4, $204-209$.

374. Napoleone, C.P.; Valori, A.; Crupi, G.; Ocello, S.; Santoro, F.; Vouhé, P.; Weerasena, N.; Gargiulo, G. An observational study of CoSeal for the prevention of adhesions in pediatric cardiac surgery. Interact. Cardiovasc. Thorac. Surg. 2009, 9, 978-982. [CrossRef]

375. Ferland, R.; Campbell, P.K. Pre-clinical evaluation of a next-generation spray adhesion barrier for multiple site adhesion protection. Surg. Technol. Int. 2009, 18, 137-143. [PubMed]

376. Mettler, L.; Audebert, A.; Lehmann-Willenbrock, E.; Schive-Peterhansl, K.; Jacobs, V.R. A randomized, prospective, controlled, multicenter clinical trial of a sprayable, site-specific adhesion barrier system in patients undergoing myomectomy. Fertil. Steril. 2004, 82, 398-404. [CrossRef] [PubMed]

377. Tchartchian, G.; Hackethal, A.; Herrmann, A.; Bojahr, B.; Wallwiener, C.; Ohlinger, R.; Ebert, A.D.; De Wilde, R.L. Evaluation of SprayShield ${ }^{\mathrm{TM}}$ Adhesion Barrier in a single center: Randomized controlled study in 15 women undergoing reconstructive surgery after laparoscopic myomectomy. Arch. Gynecol. Obstet. 2014, 290, 697-704. [CrossRef] [PubMed]

378. Sheldon, H.K.; Gainsbury, M.L.; Cassidy, M.R.; Chu, D.I.; Stucchi, A.F.; Becker, J.M. A Sprayable Hyaluronate/Carboxymethylcellulose Adhesion Barrier Exhibits Regional Adhesion Reduction Efficacy and Does Not Impair Intestinal Healing. J. Gastrointest. Surg. 2012, 16, 325-333. [CrossRef] [PubMed]

379. Fossum, G.T.; Silverberg, K.M.; Miller, C.E.; Diamond, M.P.; Holmdahl, L. Gynecologic use of Sepraspray Adhesion Barrier for reduction of adhesion development after laparoscopic myomectomy: A pilot study. Fertil. Steril. 2011, 96, 487-491. [CrossRef]

380. Berdah, S.V.; Mariette, C.; DeNet, C.; Panis, Y.; Laurent, C.; Cotte, E.; Huten, N.; Feuillet, E.L.P.; Duron, J.-J. A multicentre, randomised, controlled trial to assess the safety, ease of use, and reliability of hyaluronic acid/carboxymethylcellulose powder adhesion barrier versus no barrier in colorectal laparoscopic surgery. Trials 2014, 15, 413. [CrossRef]

381. Suto, T.; Watanabe, M.; Endo, T.; Komori, K.; Ohue, M.; Kanemitsu, Y.; Itou, M.; Takii, Y.; Yatsuoka, T.; Shiozawa, M.; et al. The Primary Result of Prospective Randomized Multicenter Trial of New Spray-Type Bio-absorbable Adhesion Barrier System (TCD-11091) Against Postoperative Adhesion Formation. J. Gastrointest. Surg. 2017, 21, 1683-1691. [CrossRef]

382. De Wilde, R.L.; Trew, G. Postoperative abdominal adhesions and their prevention in gynaecological surgery: Expert consensus position. Gynecol. Surg. 2007, 4, 161-168. [CrossRef]

383. Trew, G.H.; Pistofidis, G.A.; Brucker, S.Y.; Krämer, B.; Ziegler, N.M.; Korell, M.; Ritter, H.; McConnachie, A.; Ford, I.; Crowe, A.M.; et al. A first-in-human, randomized, controlled, subject- and reviewer-blinded multicenter study of Actamax ${ }^{\mathrm{TM}}$ Adhesion Barrier. Arch. Gynecol. Obstet. 2017, 295, 383-395. [CrossRef]

384. Kai, M.; Maeda, K.; Tasaki, M.; Kira, S.; Nakamura, S.; Chino, N.; Hagiwara, H.; Nishida, H.; Kawanishi, T. Evaluation of a Spray-type, Novel Dextrin Hydrogel Adhesion Barrier Under Laparoscopic Conditions in a Porcine Uterine Horn Adhesion Model. J. Minim. Invasive Gynecol. 2018, 25, 447-454. [CrossRef] [PubMed]

385. Yan, S.; Yue, Y.-Z.; Zeng, L.; Yue, J.; Li, W.-L.; Mao, C.-Q.; Yang, L. Effect of intra-abdominal administration of ligustrazine nanoparticles nano spray on postoperative peritoneal adhesion in rat model. J. Obstet. Gynaecol. Res. 2015, 41, 1942-1950. [CrossRef] [PubMed]

386. Dasiran, F.; Eryilmaz, R.; Isik, A.; Okan, I.; Somay, A.; Sahin, M.; Dasiran, F.; Eryilmaz, R.; Isik, A.; Okan, I.; et al. The effect of polyethylene glycol adhesion barrier (Spray Gel) on preventing peritoneal adhesions. Bratisl Lek List. 2015, 116, 379-382. [CrossRef] [PubMed]

387. Bhandarkar, D.; Nathanson, L.K.; Hills, B.A. Spray of phospholipid powder reduces peritoneal adhesions in rabbits. ANZ J. Surg. 1999, 69, 388-390. [CrossRef]

388. Wiseman, D.M.; Trout, J.R.; Diamond, M.P. The rates of adhesion development and the effects of crystalloid solutions on adhesion development in pelvic surgery. Fertil. Steril. 1998, 70, 702-711. [CrossRef]

389. Larsson, B.; Lalos, O.; Marsk, L.; Tronstad, S.-E.; Bygdeman, M.; Pehrson, S.; Joelsson, I. Effect of Intraperitoneal Instillation of 32\% Dextran 70 on Postoperative adhesion Formation after tubal surgery. Acta Obstet. Gynecol. Scand. 1985, 64, 437-441. [CrossRef]

390. Robison, R.J.; Brown, J.W.; Deschner, W.P.; Highes, B.; King, H. Prevention of Pericardial Adhesions with Dextran 70. Ann. Thorac. Surg. 1984, 37, 488-490. [CrossRef]

391. Brown, C.B.; Luciano, A.A.; Martin, D.; Peers, E.; Scrimgeour, A.; Dizerega, G.S. Adept (icodextrin 4\% solution) reduces adhesions after laparoscopic surgery for adhesiolysis: A double-blind, randomized, controlled study. Fertil. Steril. 2007, 88, 1413-1426. [CrossRef]

392. Van den Tol, P.; Raa, S.; van Grevenstein, H.; Marquet, R.; van Eijck, C.; Jeekel, H. Icodextrin reduces postoperative adhesion formation in rats without affecting peritoneal metastasis. Surgery 2005, 137, 348-354. [CrossRef] [PubMed]

393. Wallwiener, C.; Brucker, S.; Hierlemann, H.; Brochhausen, C.; Solomayer, E. Innovative barriers for peritoneal adhesion prevention: Liquid or solid? A rat uterine horn model. Fertil. Steril. 2006, 86, 1266-1276. [CrossRef] [PubMed]

394. Müller, S.A.; Treutner, K.H.; Anurov, M.; Titkova, S.; Oettinger, A.; Schumpelick, V. Experimental evaluation of phospholipids and icodextrin in re-formation of peritoneal adhesions. BJS 2003, 90, 1604-1607. [CrossRef] 
395. Menzies, D.; Pascual, M.H.; Walz, M.K.; Duron, J.J.; Tonelli, F.; Crowe, A.; Knight, A. Use of Icodextrin $4 \%$ Solution in the Prevention of Adhesion Formation Following General Surgery: From the Multicentre ARIEL Registry. Ann. R. Coll. Surg. Engl. 2006, 88, 375-382. [CrossRef] [PubMed]

396. Di Zerega, G.S.; Verco, S.J.; Young, P.; Kettel, M.; Kobak, W.; Martin, D.; Sanfilippo, J.; Peers, E.M.; Scrimgeour, A.; Brown, C.B. A randomized, controlled pilot study of the safety and efficacy of $4 \%$ icodextrin solution in the reduction of adhesions following laparoscopic gynaecological surgery. Hum. Reprod. 2002, 17, 1031-1038. [CrossRef]

397. Trew, G.; Pistofidis, G.; Pados, G.; Lower, A.; Mettler, L.; Wallwiener, D.; Korell, M.; Pouly, J.-L.; Coccia, M.E.; Audebert, A.; et al. Gynaecological endoscopic evaluation of $4 \%$ icodextrin solution: A European, multicentre, double-blind, randomized study of the efficacy and safety in the reduction of de novo adhesions after laparoscopic gynaecological surgery. Hum. Reprod. 2011, 26, 2015-2027. [CrossRef]

398. Mathisen, S.R.; Wu, H.D.; Sauvage, L.R.; Walker, M.W. Prevention of retrosternal adhesions after pericardiotomy. J. Thorac. Cardiovasc. Surg. 1986, 92, 92-98. [CrossRef]

399. Segesser, L.; Cox, J.; Faidutti, B. Equine pericardial xenograft in orthotopic position: Early results. Thorac. Cardiovasc. Surg. 1986, 34, 35-38. [CrossRef]

400. Shen, J.; Xu, Z.W. Combined Application of Acellular Bovine Pericardium and Hyaluronic Acid in Prevention of Postoperative Pericardial Adhesion. Artif. Organs 2014, 38, 224-230. [CrossRef]

401. He, T.; Zou, C.; Song, L.; Wang, N.; Yang, S.; Zeng, Y.; Wu, Q.; Zhang, W.; Chen, Y.; Gong, C. Improving Antiadhesion Effect of Thermosensitive Hydrogel with Sustained Release of Tissue-type Plasminogen Activator in a Rat Repeated-Injury Model. ACS Appl. Mater. Interfaces 2016, 8, 33514-33520. [CrossRef]

402. Choi, G.J.; Kang, H.; Hong, M.E.; Shin, H.Y.; Baek, C.W.; Jung, Y.H.; Lee, Y.; Kim, J.W.; Park, I.L.K.; Cho, W.J. Effects of a Lidocaine-Loaded Poloxamer/Alginate/CaCl2 Mixture on Postoperative Pain and Adhesion in a Rat Model of Incisional Pain. Anesth. Analg. 2017, 125, 320-327. [CrossRef]

403. Baek, S.; Park, H.; Park, Y.; Kang, H.; Lee, D. Development of a Lidocaine-Loaded Alginate/CMC/PEO Electrospun Nanofiber Film and Application as an Anti-Adhesion Barrier. Polymers 2020, 12, 618. [CrossRef] [PubMed]

404. Cruz, O.A. Evaluation of Mitomycin to Limit Postoperative Adhesions in Strabismus Surgery. J. Pediatr. Ophthalmol. Strabismus 1996, 33, 89-92. [CrossRef] [PubMed]

405. Sultana, T.; Van Hai, H.; Park, M.; Lee, S.-Y.; Lee, B.-T. Controlled release of Mitomycin C from modified cellulose based thermo-gel prevents post-operative de novo peritoneal adhesion. Carbohydr. Polym. 2020, 229, 115552. [CrossRef]

406. Orhan, A.; Görmüş, N.; Toy, H.; Görmüş, I.S.; Çağlayan, O.; Tanyeli, Ö. Prevention of retrosternal pericardial adhesions after cardiac surgery with mitomycin C. Heart Lung Circ. 2014, 23, 357-362. [CrossRef] [PubMed]

407. Lee, J.E.; Abuzar, S.M.; Seo, Y.; Han, H.; Jeon, Y.; Park, E.J.; Baik, S.H.; Hwang, S.-J. Oxaliplatin-loaded chemically cross-linked hydrogels for prevention of postoperative abdominal adhesion and colorectal cancer therapy. Int. J. Pharm. 2019, 565, 50-58. [CrossRef] [PubMed]

408. Abuzar, S.M.; Ahn, J.-H.; Park, K.S.; Park, E.J.; Baik, S.H.; Hwang, S.-J. Pharmacokinetic Profile and Anti-Adhesive Effect of Oxaliplatin-PLGA Microparticle-Loaded Hydrogels in Rats for Colorectal Cancer Treatment. Pharmaceutics 2019, 11, 392. [CrossRef]

409. Lim, R.; Stucchi, A.F.; Morrill, J.M.; Reed, K.L.; Lynch, R.; Becker, J.M. The efficacy of a hyaluronate-carboxymethylcellulose bioresorbable membrane that reduces postoperative adhesions is increased by the intra-operative co-administration of a neurokinin 1 receptor antagonist in a rat model. Surgery 2010, 148, 991-999. [CrossRef]

410. Lee, J.H.; Go, A.K.; Oh, S.H.; Lee, K.E.; Yuk, S.H. Tissue anti-adhesion potential of ibuprofen-loaded PLLA-PEG diblock copolymer films. Biomaterials 2005, 26, 671-678. [CrossRef]

411. Liu, S.; Hu, C.; Li, F.; Li, X.-J.; Cui, W.; Fan, C. Prevention of Peritendinous Adhesions with Electrospun Ibuprofen-Loaded Poly(l-Lactic Acid)-Polyethylene Glycol Fibrous Membranes. Tissue Eng. Part A 2013, 19, 529-537. [CrossRef] [PubMed]

412. Zong, X.; Li, S.; Chen, E.; Garlick, B.; Kim, K.-S.; Fang, D.; Chiu, J.; Zimmerman, T.; Brathwaite, C.; Hsiao, B.S.; et al. Prevention of Postsurgery-Induced Abdominal Adhesions by Electrospun Bioabsorbable Nanofibrous Poly(lactide-co-glycolide)-Based Membranes. Ann. Surg. 2004, 240, 910-915. [CrossRef] [PubMed]

413. Jiang, S.; Zhao, X.; Chen, S.; Pan, G.; Song, J.; He, N.; Li, F.; Cui, W.; Fan, C. Down-regulating ERK1/2 and SMAD2/3 phosphorylation by physical barrier of celecoxib-loaded electrospun fibrous membranes prevents tendon adhesions. Biomaterials 2014, 35, 9920-9929. [CrossRef] [PubMed]

414. Wang, H.; Li, M.; Hu, J.; Wang, C.; Xu, S.; Han, C.C. Multiple Targeted Drugs Carrying Biodegradable Membrane Barrier: Anti-Adhesion, Hemostasis, and Anti-Infection. Biomacromolecules 2013, 14, 954-961. [CrossRef] [PubMed]

415. Lee, J.H.; Shin, Y.C.; Yang, W.J.; Park, J.-C.; Hyon, S.-H.; Han, D.-W. Epigallocatechin-3-O-Gallate-Loaded Poly(lactic-co-glycolic acid) Fibrous Sheets as Anti-Adhesion Barriers. J. Biomed. Nanotechnol. 2015, 11, 1461-1471. [CrossRef] [PubMed]

416. Zhao, X.; Jiang, S.; Liu, S.; Chen, S.; Lin, Z.Y.; Pan, G.; He, F.; Li, F.; Fan, C.; Cui, W. Optimization of intrinsic and extrinsic tendon healing through controllable water-soluble mitomycin-C release from electrospun fibers by mediating adhesion-related gene expression. Biomaterials 2015, 61, 61-74. [CrossRef] [PubMed]

417. Wang, Y.; Pang, X.; Luo, J.; Wen, Q.; Wu, Z.; Ding, Q.; Zhao, L.; Yang, L.; Wang, B.; Fu, S. Naproxen Nanoparticle-Loaded Thermosensitive Chitosan Hydrogel for Prevention of Postoperative Adhesions. ACS Biomater. Sci. Eng. 2019, 5, 1580-1588. [CrossRef] 
418. Wilczewska, A.Z.; Niemirowicz, K.; Markiewicz, K.H.; Car, H. Nanoparticles as drug delivery systems. Pharmacol. Rep. 2012, 64, 1020-1037. [CrossRef]

419. Liu, S.; Zhao, J.; Ruan, H.; Wang, W.; Wu, T.; Cui, W.; Fan, C. Antibacterial and anti-adhesion effects of the silver nanoparticlesloaded poly(l-lactide) fibrous membrane. Mater. Sci. Eng. C 2013, 33, 1176-1182. [CrossRef]

420. Hu, C.; Liu, S.; Zhang, Y.; Li, B.; Yang, H.; Fan, C.; Cui, W. Long-term drug release from electrospun fibers for in vivo inflammation prevention in the prevention of peritendinous adhesions. Acta Biomater. 2013, 9, 7381-7388. [CrossRef]

421. Liu, S.; Qin, M.; Hu, C.; Wu, F.; Cui, W.; Jin, T.; Fan, C. Tendon healing and anti-adhesion properties of electrospun fibrous membranes containing bFGF loaded nanoparticles. Biomaterials 2013, 34, 4690-4701. [CrossRef]

422. Zhou, Y.; Zhu, C.; Wu, Y.F.; Zhang, L.; Tang, J.B. Effective modulation of transforming growth factor- $\beta 1$ expression through engineered microRNA-based plasmid-loaded nanospheres. Cytotherapy 2015, 17, 320-329. [CrossRef]

423. Zhou, Y.; Zhang, L.; Zhao, W.; Wu, Y.; Zhu, C.; Yang, Y. Nanoparticle-mediated delivery of TGF- $\beta 1$ miRNA plasmid for preventing flexor tendon adhesion formation. Biomaterials 2013, 34, 8269-8278. [CrossRef]

424. Yang, Q.Q.; Shao, Y.X.; Zhang, L.Z.; Zhou, Y.L. Therapeutic strategies for flexor tendon healing by nanoparticle-mediated co-delivery of bFGF and VEGFA genes. Colloids Surf. B Biointerfaces 2018, 164, 165-176. [CrossRef] [PubMed]

425. Chaturvedi, A.A.; Lomme, R.; Hendriks, T.; van Goor, H. Prevention of postsurgical adhesions using an ultrapure alginate-based gel. BJS 2013, 100, 904-910. [CrossRef] [PubMed]

426. Na, S.Y.; Oh, S.H.; Song, K.S.; Lee, J.H. Hyaluronic acid/mildly crosslinked alginate hydrogel as an injectable tissue adhesion barrier. J. Mater. Sci. Mater. Electron. 2012, 23, 2303-2313. [CrossRef]

427. Ito, T.; Yeo, Y.; Highley, C.; Bellas, E.; Kohane, D. Dextran-based in situ cross-linked injectable hydrogels to prevent peritoneal adhesions. Biomaterials 2007, 28, 3418-3426. [CrossRef] [PubMed]

428. Oh, S.H.; Kim, J.K.; Song, K.S.; Noh, S.M.; Ghil, S.H.; Yuk, S.H.; Lee, J.H. Prevention of postsurgical tissue adhesion by antiinflammatory drug-loaded pluronic mixtures with sol-gel transition behavior. J. Biomed. Mater. Res. Part A 2005, 72, 306-316. [CrossRef]

429. Hong, J.H.; Choe, J.W.; Kwon, G.Y.; Cho, D.Y.; Sohn, D.S.; Kim, S.W.; Woo, Y.C.; Lee, C.J.; Kang, H. The Effects of Barrier Materials on Reduction of Pericardial Adhesion Formation in Rabbits: A Comparative Study of a Hyaluronan-Based Solution and a Temperature Sensitive Poloxamer Solution/Gel Material. J. Surg. Res. 2011, 166, 206-213. [CrossRef]

430. Kim, H.-J.; Kang, H.; Kim, M.-K.; Han, S.-S. The Effects of Barrier Agents in Postoperative Pelvic Adhesion Formation: A Comparative Study of a Temperature-Sensitive Poloxamer-Based Solution/Gel and a Hyaluronic Acid-Based Solution in a Rat Uterine Horn Model. J. Laparoendosc. Adv. Surg. Tech. 2018, 28, 134-139. [CrossRef]

431. Kim, S.G.; Song, K.Y.; Lee, H.H.; Kim, E.Y.; Lee, J.H.; Jeon, H.M.; Jeon, K.H.; Jin, H.M.; Kim, D.J.; Kim, W.; et al. Efficacy of an antiadhesive agent for the prevention of intra-abdominal adhesions after radical gastrectomy: A prospective randomized, multicenter trial. Medicine 2019, 98, e15141. [CrossRef]

432. Oh, S.H.; Na, S.Y.; Song, K.S.; Lee, J.H. Sprayable powder of hyaluronate embedded in mildly cross-linked alginate as a post-surgical tissue adhesion barrier. Macromol. Res. 2013, 21, 1263-1269. [CrossRef]

433. Schrøder, M.; Willumsen, H.; Hansen, J.P.; Hansen, O.H. Peritoneal adhesion formation after the use of oxidized cellulose (Surgicel) and gelatin sponge (Spongostan) in rats. Acta Chir. Scand. 1982, 148, 595-596.

434. Horii, T.; Tsujimoto, H.; Miyamoto, H.; Yamanaka, K.; Tanaka, S.; Torii, H.; Ozamoto, Y.; Takamori, H.; Nakamachi, E.; Ikada, Y.; et al. Physical and biological properties of a novel anti-adhesion material made of thermally cross-linked gelatin film: Investigation of the usefulness as anti-adhesion material. J. Biomed. Mater. Res. Part B Appl. Biomater. 2018, 106, 689-696. [CrossRef]

435. Tsujimoto, H.; Tanzawa, A.; Matoba, M.; Hashimoto, A.; Suzuki, S.; Morita, S.; Ikada, Y.; Hagiwara, A. The anti-adhesive effect of thermally cross-linked gelatin film and its influence on the intestinal anastomosis in canine models. J. Biomed. Mater. Res. Part B Appl. Biomater. 2012, 101, 99-109. [CrossRef]

436. Torii, H.; Takagi, T.; Urabe, M.; Tsujimoto, H.; Ozamoto, Y.; Miyamoto, H.; Ikada, Y.; Hagiwara, A. Anti-adhesive effects of a newly developed two-layered gelatin sheet in dogs. J. Obstet. Gynaecol. Res. 2017, 43, 1317-1325. [CrossRef] [PubMed]

437. Shahram, E.; Sadraie, S.H.; Kaka, G.; Khoshmohabat, H.; Hosseinalipour, M.; Panahi, F.; Naimi-Jamal, M.R. Evaluation of chitosan-gelatin films for use as postoperative adhesion barrier in rat cecum model. Int. J. Surg. 2013, 11, 1097-1102. [CrossRef]

438. De Clercq, K.; Schelfhout, C.; Bracke, M.; de Wever, O.; van Bockstal, M.; Ceelen, W.; Remon, J.P.; Vervaet, C. Genipin-crosslinked gelatin microspheres as a strategy to prevent postsurgical peritoneal adhesions: In vitro and in vivo characterization. Biomaterials 2016, 96, 33-46. [CrossRef] [PubMed]

439. Lee, M.-W.; Tsai, H.-F.; Wen, S.-M.; Huang, C.-H. Photocrosslinkable gellan gum film as an anti-adhesion barrier. Carbohydr. Polym. 2012, 90, 1132-1138. [CrossRef]

440. Izumi, Y.; Yamamoto, M.; Kawamura, M.; Adachi, T.; Kobayashi, K. Cross-linked poly (gamma-glutamic acid) attenuates peritoneal adhesion in a rat model. Surgery 2007, 141, 678-681. [CrossRef]

441. Evrard, V.; De Bellis, A.; Boeckx, W.; Brosens, I. Surgery: Peritoneal healing after fibrin glue application: A comparative study in a rat model. Hum. Reprod. 1996, 11, 1877-1880. [CrossRef] [PubMed]

442. Takeuchi, H.; Toyonari, Y.; Mitsuhashi, N.; Kuwabara, Y. Effects of fibrin glue on postsurgical adhesions after uterine or ovarian surgery in rabbits. J. Obstet. Gynaecol. Res. 1997, 23, 479-484. [CrossRef] 
443. Takeuchi, H.; Awaji, M.; Hashimoto, M.; Nakano, Y.; Mitsuhashi, N.; Kuwabara, Y. Reduction of adhesions with fibrin glue after laparoscopic excision of large ovarian endometriomas. J. Am. Assoc. Gynecol. Laparosc. 1996, 3, 575-579. [CrossRef]

444. Takeuchi, H.; Kitade, M.; Kikuchi, I.; Shimanuki, H.; Kumakiri, J.; Kinoshita, K. Adhesion-prevention effects of fibrin sealants after laparoscopic myomectomy as determined by second-look laparoscopy: A prospective, randomized, controlled study. $J$. Reprod. Med. 2005, 50, 571-577.

445. Moro, H.; Hayashi, J.-I.; Ohzeki, H.; Nakayama, T.; Namura, O.; Hanzawa, K.; Yagi, N. The effect of fibrin glue on inhibition of pericardial adhesions. Gen. Thorac. Cardiovasc. Surg. 1999, 47, 79-84. [CrossRef]

446. Koçak, I.; Unlü, C.; Akçan, Y.; Yakin, K. Reduction of adhesion formation with cross-linked hyaluronic acid after peritoneal surgery in rats. Fertil. Steril. 1999, 72, 873-878. [CrossRef]

447. Sikkink, C.J.; de Man, B.; Bleichrodt, R.P.; van Goor, H. Auto-cross-linked hyaluronic acid gel does not reduce intra-abdominal adhesions or abscess formation in a rat model of peritonitis. J. Surg. Res. 2006, 136, 255-259. [CrossRef] [PubMed]

448. Belluco, C.; Meggiolaro, F.; Pressato, D.; Pavesio, A.; Bigon, E.; Donà, M.; Forlin, M.; Nitti, D.; Lise, M. Prevention of Postsurgical Adhesions with an Autocrosslinked Hyaluronan Derivative Gel. J. Surg. Res. 2001, 100, 217-221. [CrossRef]

449. Mais, V.; Bracco, G.; Litta, P.; Gargiulo, T.; Melis, G. Reduction of postoperative adhesions with an auto-crosslinked hyaluronan gel in gynaecological laparoscopic surgery: A blinded, controlled, randomized, multicentre study. Hum. Reprod. 2006, 21, 1248-1254. [CrossRef] [PubMed]

450. Mayes, S.M.; Davis, J.; Scott, J.; Aguilar, V.; Zawko, S.A.; Swinnea, S.; Peterson, D.L.; Hardy, J.G.; Schmidt, C.E. Polysaccharidebased films for the prevention of unwanted postoperative adhesions at biological interfaces. Acta Biomater. 2020, 106, 92-101. [CrossRef]

451. Sakai, S.; Ueda, K.; Taya, M. Peritoneal adhesion prevention by a biodegradable hyaluronic acid-based hydrogel formed in situ through a cascade enzyme reaction initiated by contact with body fluid on tissue surfaces. Acta Biomater. 2015, 24, 152-158. [CrossRef] [PubMed]

452. Yeo, Y.; Highley, C.B.; Bellas, E.; Ito, T.; Marini, R.; Langer, R.; Kohane, D.S. In situ cross-linkable hyaluronic acid hydrogels prevent post-operative abdominal adhesions in a rabbit model. Biomaterials 2006, 27, 4698-4705. [CrossRef]

453. Ito, T.; Yeo, Y.; Highley, C.B.; Bellas, E.; Benitez, C.A.; Kohane, D.S. The prevention of peritoneal adhesions by in situ cross-linking hydrogels of hyaluronic acid and cellulose derivatives. Biomaterials 2007, 28, 975-983. [CrossRef]

454. Bang, S.; Lee, E.; Ko, Y.-G.; Kim, W.I.; Kwon, O.H. Injectable pullulan hydrogel for the prevention of postoperative tissue adhesion. Int. J. Biol. Macromol. 2016, 87, 155-162. [CrossRef]

455. O'Sullivan, D.; O'Riordain, M.; O'Connell, R.P.; Dineen, M.; Brady, M.P. Peritoneal adhesion formation after lysis: Inhibition by polyethylene glycol 4000. BJS 2005, 78, 427-429. [CrossRef] [PubMed]

456. Lei, K.; Chen, Y.; Wang, J.; Peng, X.; Yu, L.; Ding, J. Non-invasive monitoring of in vivo degradation of a radiopaque thermoreversible hydrogel and its efficacy in preventing post-operative adhesions. Acta Biomater. 2017, 55, 396-409. [CrossRef] [PubMed]

457. Yu, L.; Hu, H.; Chen, L.; Bao, X.; Li, Y.; Chen, L.; Xu, G.; Ye, X.; Ding, J. Comparative studies of thermogels in preventing post-operative adhesions and corresponding mechanisms. Biomater. Sci. 2014, 2, 1100-1109. [CrossRef] [PubMed]

458. Singh, D.H.; Han, S.S.; Son, J.H.; Kim, S.C. Poly(ethylene glycol) dicarboxylate/poly(ethylene oxide) hydrogel film co-crosslinked by electron beam irradiation as an anti-adhesion barrier. Mater. Sci. Eng. C 2015, 46, 195-201.

459. Yang, D.-J.; Chen, F.; Xiong, Z.-C.; Xiong, C.-D.; Wang, Y.-Z. Tissue anti-adhesion potential of biodegradable PELA electrospun membranes. Acta Biomater. 2009, 5, 2467-2474. [CrossRef] [PubMed]

460. Bakkum, E.; Trimbos, J.; Dalmeijer, R.; Blitterswijk, C. Preventing postoperative intraperitoneal adhesion formation with Polyactive $^{\mathrm{TM}}$, a degradable copolymer acting as a barrier. J. Mater. Sci. Mater. Med. 1995, 6, 41-45. [CrossRef]

461. Leach, R.E.; Henry, R.L. Reduction of postoperative adhesions in the rat uterine horn model with poloxamer 407. Am. J. Obstet. Gynecol. 1990, 162, 1317-1319. [CrossRef]

462. Rice, V.M.; Shanti, A.; Moghissi, K.S.; Leach, R. A comparative evaluation of Poloxamer 407 and oxidized regenerated cellulose (Interceed [TC7]) to reduce postoperative adhesion formation in the rat uterine horn model. Fertil. Steril. 1993, 59, 901-906. [PubMed]

463. Steinleitner, A.; Lambert, H.; Kazensky, C.; Cantor, B. Poloxamer 407 as an intraperitoneal barrier material for the prevention of postsurgical adhesion formation and reformation in rodent models for reproductive surgery. Obstet. Gynecol. 1991, 77, 48-52. [PubMed]

464. Sawhney, A.S.; Pathak, C.P.; Van Rensburg, J.J.; Dunn, R.C.; Hubbell, J.A. Optimization of photopolymerized bioerodible hydrogel properties for adhesion prevention. J. Biomed. Mater. Res. 1994, 28, 831-838. [CrossRef] [PubMed]

465. Li, J.; Ren, G.; Zhang, W. Reduction of Abdominal Adhesions with Elecrospun Fiber Membranes in Rat Models. J. Investig. Surg. 2017, 31, 1-8. [CrossRef]

466. Yang, B.; Gong, C.; Qian, Z.; Zhao, X.; Li, Z.; Qi, X.; Zhou, S.; Zhong, Q.; Luo, F.; Wei, Y. Prevention of post-surgical abdominal adhesions by a novel biodegradable thermosensitive PECE hydrogel. BMC Biotechnol. 2010, 10, 65. [CrossRef]

467. Cook, G.B. The silicone serosal interface I. Abatement of talc adhesions in Dogs. Surgery 1964, 55, 268-273. [PubMed]

468. Weis, C.; Odermatt, E.K.; Funke, Z.; Wehner, T.; Freytag, D. Poly(vinyl alcohol) membranes for adhesion prevention. J. Biomed. Mater. Res. 2004, 70, 191-202. [CrossRef] 
469. De Oliveira, P.P.M.; Bavaresco, V.P.; Silveira-Filho, L.M.; Schenka, A.A.; Vilarinho, K.A.D.S.; Severino, E.S.B.D.O.; Petrucci, O. Use of a novel polyvinyl alcohol membrane as a pericardial substitute reduces adhesion formation and inflammatory response after cardiac reoperation. J. Thorac. Cardiovasc. Surg. 2014, 147, 1405-1410. [CrossRef] [PubMed]

470. Bae, S.H.; Son, S.R.; Kumar Sakar, S.; Nguyen, T.H.; Kim, S.W.; Min, Y.K.; Lee, B.-T. Evaluation of the potential anti-adhesion effect of the PVA/Gelatin membrane. J. Biomed. Mater. Res. B Appl. Biomater. 2014, 102, 840-849. [CrossRef]

471. Renz, B.W.; Leitner, K.; Odermatt, E.; Worthley, D.L.; Angele, M.K.; Jauch, K.W.; Lang, R.A. PVA gel as a potential adhesion barrier: A safety study in a large animal model of intestinal surgery. Langenbeck's Arch. Surg. 2014, 399, 349-357. [CrossRef]

472. Deerenberg, E.; Mulder, I.M.; Ditzel, M.; Slieker, J.C.; Bemelman, W.A.; Jeekel, J.; Lange, J.F. Polyvinyl Alcohol Hydrogel Decreases Formation of Adhesions in a Rat Model of Peritonitis. Surg. Infect. 2012, 13, 321-325. [CrossRef]

473. Lang, R.; Baumann, P.; Schmoor, C.; Odermatt, E.K.; Wente, M.N.; Jauch, K.-W. A-Part Gel, an adhesion prophylaxis for abdominal surgery: A randomized controlled phase I-II safety study [NCT00646412]. Ann. Surg. Innov. Res. 2015, 9, 5. [CrossRef] [PubMed]

474. Lang, R.A.; Weisgerber, C.; Grüntzig, P.M.; Weis, C.; Odermatt, E.K.; Kirschner, M.H. Polyvinyl Alcohol Gel Prevents Adhesion Re-Formation After Adhesiolysis in a Rabbit Model. J. Surg. Res. 2009, 153, 12-16. [CrossRef] [PubMed]

475. Townsend, K.L.; Race, A.; Keane, M.; Miller, W.; Dishaw, L.; Fisher, E.R.; Russell, D.S.; Allen, M.J. A Novel Hydrogel-Coated Polyester Mesh Prevents Postsurgical Adhesions in a Rat Model. J. Surg. Res. 2011, 167, e117-e124. [CrossRef] [PubMed]

476. Freytag, C.; Odermatt, E.K. Standard Biocompatibility Studies Do Not Predict All Effects of PVA/CMC Anti-Adhesive Gel in vivo. Eur. Surg. Res. 2016, 56, 109-122. [CrossRef]

477. Hu, C.; Tang, F.; Wu, Q.; Guo, B.; Long, W.A.; Ruan, Y.; Li, L. Novel Trilaminar Polymeric Antiadhesion Membrane Prevents Postoperative Pericardial Adhesion. Ann. Thorac. Surg. 2021, 111, 184-189. [CrossRef] [PubMed]

478. Ersoy, E.; Ozturk, V.; Yazgan, A.; Ozdogan, M.; Gundogdu, H. Effect of Polylactic Acid Film Barrier on Intra-Abdominal Adhesion Formation. J. Surg. Res. 2008, 147, 148-152. [CrossRef] [PubMed]

479. Iliopoulos, J.; Cornwall, G.B.; Evans, R.; Manganas, C.; Thomas, K.; Newman, D.; Walsh, W.; Iliopoulos, J.; Cornwall, G.B.; Evans, R.; et al. Evaluation of a bioabsorable polylactide film in a large animal model for the reduction of retrosternal adhesions. J. Surg. Res. 2004, 118, 144-153. [CrossRef]

480. Hinoki, A.; Saito, A.; Kinoshita, M.; Yamamoto, J.; Saitoh, D.; Takeoka, S. Polylactic acid nanosheets in prevention of postoperative intestinal adhesion and their effects on bacterial propagation in an experimental model. BJS 2016, 103, 692-700. [CrossRef]

481. Chen, G.; Liu, T. Therapeutic evaluation of the polylactic acid gel (PLA-G) used for preventing skin flap adhesion in modified radical mastectomy. J. Biomed. Eng. 2013, 30, 1276-1278.

482. Yamaoka, T.; Njatawidjaja, E.; Kasai, A.; Agudelo, C.A.; Ehashi, T.; Kakinoki, S.; Kato, S.; Mahara, A. Elastic/adhesive doublelayered PLA-PEG multiblock copolymer membranes for postoperative adhesion prevention. Polym. Degrad. Stab. 2013, 98, 2168-2176. [CrossRef]

483. Okuyama, N.; Wang, C.Y.; Rose, E.; Rodgers, K.; Pines, E.; Dizerega, G.S.; Oz, M.C. Reduction of retrosternal and pericardial adhesions with rapidly resorbable polymer films. Ann. Thorac. Surg. 1999, 68, 913-918. [CrossRef]

484. Kaushal, S.; Patel, S.K.; Goh, S.-K.; Sood, A.; Walker, B.L.; Backer, C.L. A novel combination of bioresorbable polymeric film and expanded polytetrafluoroethylene provides a protective barrier and reduces adhesions. J. Thorac. Cardiovasc. Surg. 2011, 141, 789-795. [CrossRef] [PubMed]

485. Lo, H.-Y.; Kuo, H.-T.; Huang, Y.-Y. Application of Polycaprolactone as an Anti-Adhesion Biomaterial Film. Artif. Organs 2010, 34, 648-653. [CrossRef]

486. Bölgen, N.; Vargel, I.; Korkusuz, P.; Menceloğlu, Y.Z.; Pişkin, E. In vivo performance of antibiotic embedded electrospun PCL membranes for prevention of abdominal adhesions. J. Biomed. Mater. Res. B Appl. Biomater. 2007, 81, 530-543. [CrossRef]

487. Jiang, S.; Wang, W.; Yan, H.; Fan, C. Prevention of Intra-Abdominal Adhesion by Bi-Layer Electrospun Membrane. Int. J. Mol. Sci. 2013, 14, 11861-11870. [CrossRef]

488. Zhang, Z.; Ni, J.; Chen, L.; Yu, L.; Xu, J.; Ding, J. Biodegradable and thermoreversible PCLA-PEG-PCLA hydrogel as a barrier for prevention of post-operative adhesion. Biomaterials 2011, 32, 4725-4736. [CrossRef]

489. Qian, Z.; Yang, B.; Gong, C.-Y.; Zhao, X.; Zhou, S.; Li, Z.; Qi, X.; Zhong, Q.; Luo, F. Preventing postoperative abdominal adhesions in a rat model with PEG-PCL-PEG hydrogel. Int. J. Nanomed. 2012, 7, 547-557. [CrossRef]

490. Gong, C.; Wu, Q.; Li, L.; Wang, N.; Gao, X.; Wang, B.; Liu, X.; Qian, Z.; Wei, Y. Biodegradable and thermosensitive micelles inhibit ischemia-induced postoperative peritoneal adhesion. Int. J. Nanomed. 2014, 9, 727-734. [CrossRef]

491. Nkere, U.; Whawell, S.; Sarraf, C.; Schofield, J.; O’Keefe, P. Pericardial Substitution After Cardiopulmonary Bypass Surgery: A Trial of an Absorbable Patch. Thorac. Cardiovasc. Surg. 1998, 46, 77-83. [CrossRef]

492. Malm, T.; Bowald, S.; Bylock, A.; Busch, C. Prevention of postoperative pericardial adhesions by closure of the pericardium with absorbable polymer patches. An experimental study. J. Thorac. Cardiovasc. Surg. 1992, 104, 600-607. [CrossRef]

493. Frishman, G. Clinical evaluation of a viscoelastic gel for reduction of adhesions following gynaecological surgery by laparoscopy in Europe. Hum. Reprod. 2005, 20, 514520. [CrossRef]

494. Young, P.; Johns, A.; Templeman, C.; Witz, C.; Webster, B.; Ferland, R.; Diamond, M.P.; Block, K.; diZerega, G. Reduction of postoperative adhesions after laparoscopic gynecological surgery with Oxiplex/AP Gel: A pilot study. Fertil. Steril. 2005, 84, 1450-1456. [CrossRef] 
495. Fuchs, N.; Smorgick, N.; Ben Ami, I.; Vaknin, Z.; Tovbin, Y.; Halperin, R.; Pansky, M. Intercoat (Oxiplex/AP Gel) for Preventing Intrauterine Adhesions After Operative Hysteroscopy for Suspected Retained Products of Conception: Double-Blind, Prospective, Randomized Pilot Study. J. Minim. Invasive Gynecol. 2014, 21, 126-130. [CrossRef]

496. Sardo, A.D.S.; Spinelli, M.; Bramante, S.; Scognamiglio, M.; Greco, E.; Guida, M.; Cela, V.; Nappi, C. Efficacy of a Polyethylene OxideSodium Carboxymethylcellulose Gel in Prevention of Intrauterine Adhesions After Hysteroscopic Surgery. J. Minim. Invasive Gynecol. 2011, 18, 462-469. [CrossRef]

497. Rajab, T.K.; Wallwiener, M.; Planck, C.; Brochhausen, C.; Kraemer, B.; Wallwiener, C.W. A Direct Comparison of Seprafilm, Adept, Intercoat, and Spraygel for Adhesion Prophylaxis. J. Surg. Res. 2010, 161, 246-249. [CrossRef]

498. Kajihara, N.; Eto, M.; Oishi, Y.; Boku, N.; Kuwahara, K.; Nishiguchi, N.; Kotani, C.; Morita, S. Three-layered synthetic pericardial substitutes reduce postoperative pericardial adhesions. J. Thorac. Cardiovasc. Surg. 2005, 129, 18-24. [CrossRef]

499. Liu, Y.; Shu, X.Z.; Prestwich, G.D. Reduced postoperative intra-abdominal adhesions using Carbylan-SX, a semisynthetic glycosaminoglycan hydrogel. Fertil. Steril. 2007, 87, 940-948. [CrossRef]

500. Connors, R.C.; Muir, J.J.; Liu, Y.; Reiss, G.R.; Kouretas, P.C.; Whitten, M.G.; Sorenson, T.K.; Prestwich, G.D.; Bull, D.A. Postoperative Pericardial Adhesion Prevention Using Carbylan-SX in a Rabbit Model. J. Surg. Res. 2007, 140, 237-242. [CrossRef]

501. Kang, H.; Chung, Y.S.; Kim, S.W.; Choi, G.J.; Kim, B.G.; Park, S.W.; Seok, J.W.; Hong, J. Effect of Temperature-Sensitive Poloxamer Solution/Gel Material on Pericardial Adhesion Prevention: Supine Rabbit Model Study Mimicking Cardiac Surgery. PLoS ONE 2015, 10, e0143359. [CrossRef]

502. Fu, S.Z.; Li, Z.; Fan, J.M.; Meng, X.H.; Shi, K.; Qu, Y.; Yang, L.L.; Wu, J.B.; Fan, J.; Luot, F.; et al. Biodegradable and thermosensitive monomethoxy poly(ethylene glycol)-poly(lactic acid) hydrogel as a barrier for prevention of post-operative abdominal adhesion. J. Biomed. Nanotechnol. 2014, 10, 427-435. [CrossRef]

503. Niu, L.; Feng, C.; Shen, C.; Wang, B.; Zhang, X. PLGA/PLCA casting and PLGA/PDPA electrospinning bilayer film for prevention of postoperative adhesion. J. Biomed. Mater. Res. Part B Appl. Biomater. 2019, 107, 2030-2039. [CrossRef]

504. Sezer, U.A.; Sanko, V.; Gulmez, M.; Aru, B.; Sayman, E.; Aktekin, A.; Aker, F.V.; Demirel, G.Y.; Sezer, S. Polypropylene composite hernia mesh with anti-adhesion layer composed of polycaprolactone and oxidized regenerated cellulose. Mater. Sci. Eng. C 2019, 99, 1141-1152. [CrossRef]

505. Boudouris, O.; Autret, M.; Paris, F.X.; Karaïtianos, I.; Loisance, D.; Henry-Suchet, J. Synergic effect of Dextran 70 at $32 \%$ and an antibiotic in the prevention of peritoneal adhesions. Experimental study in rats. J. Chir. 1992, 129, 160-164.

506. Reid, R.L.; Hahn, P.M.; Spence, J.E.; Tulandi, T.; Yuzpe, A.A.; Wiseman, D. A randomized clinical trial of oxidized regenerated cellulose adhesion barrier (Interceed, TC7) alone or in combination with heparint. Fertil. Steril. 1997, 67, 23-29. [CrossRef]

507. Kaptanoğlu, L.; Kucuk, H.; Yegenoglu, A.; Uzun, H.; Eßer, M.; Mentes, C.; Kurt, N. Effects of Seprafilm and Heparin in Combination on Intra-Abdominal Adhesions. Eur. Surg. Res. 2008, 41, 203-207. [CrossRef]

508. Miyata, T.; Fususe, M.; Yamane, Y.; Noishiki, Y. A biodegradable antiadhesion collagen membrane with slow release heparin. ASAIO Trans. 1988, 34, 687-691.

509. Jamshidi-Adegani, F.; Seyedjafari, E.; Gheibi, N.; Soleimani, M.; Sahmani, M. Prevention of adhesion bands by ibuprofen-loaded PLGA nanofibers. Biotechnol. Prog. 2016, 32, 990-997. [CrossRef]

510. El-Salamouni, N.S.; Gowayed, M.A.; Labib, G.S. Controlled release Ibu-cryobarriers for the prevention of post-operative adhesions: In-vitro/in-vivo comparative study. Int. J. Pharm. 2019, 565, 70-82. [CrossRef]

511. Höckel, M.; Ott, S.; Siemann, U.; Kissel, T. Prevention of peritoneal adhesions in the rat with sustained intraperitoneal dexamethasone delivered by a novel therapeutic system. Ann. Chir. Gynaecol. 1987, 76, 306-313.

512. Chorny, M.; Mishaly, D.; Leibowitz, A.; Domb, A.J.; Golomb, G. Site-specific delivery of dexamethasone from biodegradable implants reduces formation of pericardial adhesions in rabbits. J. Biomed. Mater. Res. A 2006, 78, 276-282. [CrossRef]

513. Yeo, Y.; Adil, M.; Bellas, E.; Astashkina, A.; Chaudhary, N.; Kohane, D.S. Prevention of peritoneal adhesions with an in situ cross-linkable hyaluronan hydrogel delivering budesonide. J. Control. Release 2007, 120, 178-185. [CrossRef]

514. Lalountas, M.; Ballas, K.D.; Michalakis, A.; Psarras, K.; Asteriou, C.; Giakoustidis, D.E.; Nikolaidou, C.; Venizelos, I.; Pavlidis, T.E.; Sakantamis, A.K. Postoperative adhesion prevention using a statin-containing cellulose film in an experimental model. BJS 2012, 99, 423-429. [CrossRef]

515. Corrales, F.; Corrales, M.; Schirmer, C.C. Preventing intraperitoneal adhesions with vitamin E and sodium hyaluronate/ carboxymethylcellulose: A comparative study in rats. Acta Cir. Bras. 2008, 23, 36-41. [CrossRef] [PubMed]

516. Bothin, C. Counteracting postsurgical adhesions-the effect of combining oxidized regenerated cellulose and tissue plasminogen activator. Int. J. Fertil. Menopaus. Stud. 1995, 40, 102-105.

517. Yeo, Y.; Bellas, E.; Highley, C.B.; Langer, R.; Kohane, D.S. Peritoneal adhesion prevention with an in situ cross-linkable hyaluronan gel containing tissue-type plasminogen activator in a rabbit repeated-injury model. Biomaterials 2007, 28, 3704-3713. [CrossRef]

518. Cooper, K.; Young, J.; Wadsworth, S.; Cui, H.; Dizerega, G.S.; Rodgers, K.E. Reduction of Post-Surgical Adhesion Formation with Tranilast. J. Surg. Res. 2007, 141, 153-161. [CrossRef]

519. Jackson, J.K.; Skinner, K.C.; Burgess, L.; Sun, T.; Hunter, W.L.; Burt, H.M. Paclitaxel-loaded crosslinked hyaluronic acid films for the prevention of postsurgical adhesions. Pharm. Res. 2002, 19, 411-417. [CrossRef]

520. Gong, C.; Yang, B.; Qian, Z.; Zhao, X.; Wu, Q.; Qi, X.; Wang, Y.; Guo, G.; Kan, B.; Luo, F.; et al. Improving intraperitoneal chemotherapeutic effect and preventing postsurgical adhesions simultaneously with biodegradable micelles. Nanomedicine 2012, 8, 963-973. [CrossRef] [PubMed] 
521. Qazi, S.; Kjaergaard, B.; Yang, F.; Shen, H.; Wang, S.; Zhang, N.; Vyberg, M.; Wøyen, A.; Andreasen, J.J. No Effect of Rapamycin on Cardiac Adhesion Formation: A Drug-Loaded Bioresorbable Polylactone Patch in a Porcine Cardiac Surgical Model. Eur. Surg. Res. 2016, 56, 76-85. [CrossRef]

522. Wei, G.; Zhou, C.; Wang, G.; Fan, L.; Wang, K.; Li, X. Keratinocyte Growth Factor Combined with a Sodium Hyaluronate Gel Inhibits Postoperative Intra-Abdominal Adhesions. Int. J. Mol. Sci. 2016, 17, 1611. [CrossRef] [PubMed]

523. Lopes, J.B.; Dallan, L.A.O.; Moreira, L.F.P.; Campana-Filho, S.P.; Gutierrez, P.S.; Lisboa, L.A.F.; De Oliveira, S.A.; Stolf, N.A.G. Synergism Between Keratinocyte Growth Factor and Carboxymethyl Chitosan Reduces Pericardial Adhesions. Ann. Thorac. Surg. 2010, 90, 566-572. [CrossRef] [PubMed]

524. Cui, H.; Gensini, M.; Kataria, R.; Twaddle, T.; Zhang, J.; Wadsworth, S.; Petrilli, J.; Rodgers, K.; Dizerega, G.; Cooper, K. Reducing post-surgical adhesions utilizing a drug-enhanced device: Sodium carboxymethylcellulose aqueous gel/poly(p-dioxanone) and Tranilast. Biomed. Mater. 2008, 4, 015001. [CrossRef]

525. Chang, Y.; Lai, P.-H.; Wang, C.-C.; Chen, S.-C.; Chang, W.-C.; Sung, H.-W. Mesothelium regeneration on acellular bovine pericardia loaded with an angiogenic agent (ginsenoside Rg1) successfully reduces postsurgical pericardial adhesions. J. Thorac. Cardiovasc. Surg. 2006, 132, 867-874.e3. [CrossRef] [PubMed]

526. Campos-Cuerva, R.; Fernández-Muñoz, B.; López, F.F.; Arenas, S.P.; Santos-Gonzalez, M.; Lopez-Navas, L.; Alaminos, M.; Campos, A.; Muntané, J.; Cepeda-Franco, C.; et al. Nanostructured fibrin agarose hydrogel as a novel haemostatic agent. J. Tissue Eng. Regen. Med. 2019, 13, 664-673. [CrossRef]

527. Mais, V.; Peiretti, M.; Minerba, L. The Improvement of Laparoscopic Surgical Skills Obtained by Gynecologists after Ten Years of Clinical Training Can Reduce Peritoneal Adhesion Formation during Laparoscopic Myomectomy: A Retrospective Cohort Study. BioMed Res. Int. 2017, 2017, 9068647. [CrossRef] [PubMed]

528. Corona, R.; Binda, M.M.; Adamyan, L.; Gomel, V.; Koninckx, P.R. N2O strongly prevents adhesion formation and postoperative pain in open surgery through a drug-like effect. Gynecol. Surg. 2017, 14, 21. [CrossRef]

529. Wu, W.; Cheng, R.; das Neves, J.; Tang, J.; Xiao, J.; Ni, Q.; Liu, X.; Pan, G.; Li, D.; Cui, W.; et al. Advances in biomaterials for preventing tissue adhesion. J. Control. Release 2017, 261, 318-336. [CrossRef] [PubMed] 